\title{
Delayed activation of the DNA replication licensing system in Lgr5(+) intestinal stem cells
}

\author{
T.D. Carroll ${ }^{1}$, I.P. Newton ${ }^{1}$, Y. Chen ${ }^{1}, \underline{\text { J.J. Blow }}^{*^{2}}, \underline{\text { I. Näthke }}^{*^{1}}$ \\ Affiliations: ${ }^{1}$ Cell \& Developmental Biology and ${ }^{2}$ Centre for Gene Regulation and Expression, \\ University of Dundee, Dundee, Scotland, UK, DD15EH \\ *Correspondence to: j.j.blow@dundee.ac.uk or i.s.nathke@dundee.ac.uk
}

\section{ABSTRACT}

During late mitosis and early $\mathrm{G}_{1}$, replication origins are licensed for replication by binding to double hexamers of MCM2-7. Here, we investigate how licensing and proliferative commitment are coupled in the small-intestinal epithelium. We developed a method for identifying cells in intact tissue containing DNA-bound MCM2-7. Interphase cells above the transit-amplifying compartment had no DNA-bound MCM2-7, but still expressed MCM2-7 protein, suggesting that licensing is inhibited immediately upon differentiation. Strikingly, we found most proliferative Lgr5(+) stem cells are in an unlicensed state. This suggests that the elongated cell-cycle of intestinal stem-cells is caused by an increased $G_{1}$ length, characterised by dormant periods with unlicensed origins. Significantly, the unlicensed state is lost In Apc mutant epithelium, which lacks a functional restriction point, causing licensing immediately upon $G_{1}$ entry. We propose that the unlicensed $G_{1}$ of intestinal stem cells creates a temporal window when proliferative fate decisions can be made. 


\section{Delayed activation of the DNA replication licensing system in $\operatorname{Lgr5}(+)$ intestinal stem cells}

\section{INTRODUCTION}

22 Cell division is necessary for adult tissue homeostasis. It allows for the replacement of aged or damaged cells and the provision of specialised cells critical for tissue function. The decision to proliferate is crucial, especially for stem cells, which produce daughter cells that either maintain a stem cell fate or differentiate to produce specialised cells. The rapidlyrenewing intestinal epithelium replenishes its cellular content every 4-5 days. This high turnover rate is maintained primarily by $\operatorname{Lgr} 5(+)$ intestinal stem cells in the crypt base, thought to be continually proliferative (Basak et al., 2014) as confirmed by proteomic and transcriptomic analysis (Munoz et al., 2012). There is also a quiescent stem cell-population that can re-engage with the cell-cycle to repopulate the Lgr5(+) cell population if it becomes depleted. These quiescent stem cells reside at the +4 position and constitute a subset of Lgr5(+) cells and are immature secretory lineage precursors (Buczacki et al., 2013). Lgr5(+) stem cells can divide to form transit-amplifying (TA) cells, which undergo several rounds of cell division before differentiating and losing proliferative competency (Potten and Loeffler, 1990).

How proliferative fate decisions are governed in stem cells and transit-amplifying cells is not understood. Lineage tracing studies suggest that in homeostatic intestinal tissue only 5-7 intestinal stem cells are 'active' out of the 12-16 $\operatorname{Lgr} 5(+)$ cells present in the crypt base (Baker et al., 2014, Kozar et al., 2013). Interestingly, Lgr5(+) cells have a significantly longer cell-cycle than transit-amplifying cells (Schepers et al., 2011). The functional significance of the prolonged cell-cycle time of Lgr5(+) stem cells is currently unknown, but suggests active regulation of cell-cycle progression and proliferative fate commitment. 


\section{Delayed activation of the DNA replication licensing system in $\operatorname{Lgr5}(+)$ intestinal stem cells}

Proliferative fate decisions are typically visualised by detecting markers that are present in all cell-cycle phases, and only distinguish proliferative from quiescent cells. Visualising the incorporation of labelled nucleosides such as BrdU or EdU marks cells in S-phase. The limitation of these methods is that they cannot discriminate early proliferative fate decisions made during the preceding mitosis, or in the early stages of $\mathrm{G}_{1}$. DNA replication in $\mathrm{S}$ phase depends on origin licensing, involving the regulated loading of minichromosome maintenance 2-7 (MCM2-7) complexes onto origins of DNA replication (reviewed in (Blow and Hodgson, 2002, Champeris Tsaniras et al., 2014)). During S phase, DNA-bound MCM2-7 hexamers are activated to form the catalytic core of the DNA helicase as part of the CMG (Cdc45, MCM2-7, GINS) complex (Moyer et al., 2006, Ilves et al., 2010, Makarova et al., 2012). Replication licensing is thought to occur from late mitosis throughout $G_{1}$ until passage through the restriction point (Dimitrova et al., 2002, Haland et al., 2015, Namdar and Kearsey, 2006, Symeonidou et al., 2013). Correspondingly, insufficient origin licensing directly limits the ability to progress past the restriction point causing cell cycle arrest (Alver et al., 2014, Liu et al., 2009, Shreeram et al., 2002). When functional, this licensingcheckpoint can delay S-phase if an insufficient amount of origins have been licensed.

When cells enter $\mathrm{G}_{0}, \mathrm{MCM} 2-7$ proteins are downregulated and degraded, primarily via E2Fmediated transcriptional control of MCM2-7, Cdc6 and Cdt1 (Leone et al., 1998, Ohtani et al., 1999, Williams et al., 1998). This prevents terminally differentiated cells from re-entering the cell cycle. In mammalian cells, artificial induction of quiescence through contact inhibition leads to gradual downregulation of $\mathrm{Cdc6}$ and MCM2-7 over several days (Kingsbury et al., 2005). These features have led to the suggestion that quiescence can be defined by an unlicensed state (Blow and Hodgson, 2002). Equally, the licensing status can 


\section{Delayed activation of the DNA replication licensing system in $\operatorname{Lgr5(+)}$ intestinal stem cells}

66

67

define a different restriction point that signals proliferative fate commitment at the end of mitosis and in early $\mathrm{G}_{1}$, independently of the $\mathrm{Rb} / \mathrm{E} 2 \mathrm{~F}$ restriction point.

The dynamics of replication licensing in the intricate cellular hierarchy of a complex, rapidly renewing adult tissue, is not understood. Therefore, we investigated the licensing system in the intestinal epithelium, aiming to understand dynamics of early cell-cycle commitment in stem and transit-amplifying cells and during terminal differentiation.

\section{MATERIALS AND METHODS}

\section{Mice}

All experiments were performed under UK home office guidelines. CL57BL/6 (Wild-type), R26-rtTA Col1A1-H2B-GFP (H2B-GFP), Lgr5-EGFP-IRES-CreERT2 $\left(\right.$ Lgr $\left.^{\mathrm{GFP} /+}\right)$ and Apc ${ }^{\mathrm{Min} /+}$ mice were sacrificed by cervical dislocation or $\mathrm{CO}_{2}$ asphyxiation. Fucci2aR mice (Mort et al., 2014) were a kind gift of Dr Richard Mort, University of Edinburgh.

\section{Tissue preparation: Whole small intestine}

Dissected pieces of adult mouse small-intestine were washed briefly in PBS and then fixed in $4 \%$ PFA for 3 hours, $4^{\circ} \mathrm{C}$. Intestines were cut into $2 \times 2 \mathrm{~cm}^{2}$ pieces and fixed overnight in $4 \%$ PFA, $4^{\circ} \mathrm{C}$. Tissue was embedded in $3 \%$ low melting temperature agarose and cut into $200 \mu \mathrm{m}$ sections using a Vibratome (Leica). Sections were washed in PBS, permeabilised with $2 \%$ Triton-X100 for 2 hours and incubated with Blocking Buffer (1\% BSA, 3\% Normal Goat serum, $0.2 \%$ Triton-X100 in PBS) for 2 hours, $4^{\circ} \mathrm{C}$. Tissue was incubated in Working Buffer (0.1\% BSA, 0.3\% Normal Goat Serum, 0.2\% Triton-X100 in PBS) containing primary antibody, Mcm2 (Cell Signalling, 1:500), for 48 hours, $4^{\circ} \mathrm{C}$. Sections were washed $5 \mathrm{x}$ with Working 


\section{Delayed activation of the DNA replication licensing system in $\operatorname{Lgr5(+)}$ intestinal stem cells}

87 Buffer prior to 48 hour incubation with secondary antibodies diluted in Working Buffer:

88 Alexafluor ${ }^{\mathrm{TM}}$ conjugated goat anti-rabbit (1:500, Molecular Probes) plus $5 \mu \mathrm{g} / \mathrm{ml}$ Hoechst

8933342 and Alexafluor ${ }^{\mathrm{TM}}$ conjugated Phalloidin (1:150, Molecular Probes). Sections were mounted on coverslips in Prolong Gold between 2x120 $\mu$ m spacers.

\section{Tissue preparation:}

\section{Isolating and staining crypts}

93 Small intestines were dissected, washed in PBS and opened longitudinally. Villi were

94 removed by repeated (up to 10 times) scraping of the luminal surface with a coverslip.

95 Tissue was washed in PBS, incubated in $30 \mathrm{mM}$ EDTA ( 25 minutes, $4^{\circ} \mathrm{C}$ ) and crypts isolated by vigorous shaking in PBS. Crypt suspensions were centrifuged (fixed rotor, $88 \mathrm{RCF}, 4^{\circ} \mathrm{C}$ )

97 and the pellet washed twice in cold PBS. Crypts were fixed in 4\% PFA (30min, room temperature), permeabilized in 1\% Triton-X100 (1 hour, room temperature) and blocked in Blocking Buffer $\left(2\right.$ hours, $\left.4^{\circ} \mathrm{C}\right)$. Crypts were incubated with primary antibodies diluted in Working Buffer: Mcm2 (Cell Signalling, 1:500), phospo-HistoneH3 (Abcam, 1:500), Ki67

101 (Abcam ab15580, 1:250), aGFP (Abcam, 1:500), washed 5x with Working Buffer before overnight incubation with secondary antibodies diluted in Working buffer: Alexafluor ${ }^{\mathrm{TM}}$ conjugated goat anti-mouse or anti-rabbit (1:500, Molecular Probes) or stains: Rhodamine labelled Ulex Europaeus Agglutinin I (UEA, 1:500), $5 \mu \mathrm{g} / \mathrm{ml}$ Hoechst 33342 or Alexafluor ${ }^{\mathrm{TM}}$ Gold, overnight. 
bioRxiv preprint doi: https://doi.org/10.1101/177477; this version posted February $14,2018$. The copyright holder for this preprint (which was not certified by peer review) is the author/funder. All rights reserved. No reuse allowed without permission.

\section{Delayed activation of the DNA replication licensing system in $\operatorname{Lgr5(+)}$ intestinal stem cells}

\section{CSK extraction of isolated crypts}

108 Soluble proteins were extracted from crypts isolated as described above by incubation with

109 CSK extraction buffer (10 mM HEPES, $100 \mathrm{mM} \mathrm{NaCl}, 3 \mathrm{mM} \mathrm{MgCl}$, 1 mM EGTA, $300 \mathrm{mM}$

110 sucrose, $0.2 \%$ TritonX-100, $1 \mathrm{mM}$ DTT, 2\% BSA) supplemented with protease inhibitors

111 (PMSF, Pepstatin, Leupeptin, Cystatin, $\mathrm{Na}_{3} \mathrm{VO}_{4}, \mathrm{NaF}$, aprotinin) for 20 minutes on ice prior to

112 fixation. Crypts were then fixed with 4\% PFA and processed for imaging as described above.

\section{H2B-GFP label retention}

114 H2B-GFP expression in transgenic R26-rtTA Col1A1-H2B-GFP mice was induced by replacing

115 normal drinking water with $5 \%$ sucrose water supplemented with $2 \mathrm{mg} / \mathrm{ml}$ doxycycline.

116 After 7 days, doxycycline water was replaced with normal drinking water. Subsequently,

117 mice were sacrificed after 7 days.

\section{EdU incorporation and detection}

119 Mice were injected intraperitoneally with $100 \mu \mathrm{g}$ EdU (Invitrogen) prepared in $200 \mu$ l sterile 120 PBS. Mice were sacrificed 1 hour or 17 hours post induction. For organoids, $10 \mu \mathrm{M}$ EdU was 121 included in crypt media for 1 hour before harvesting. EdU was detected by Click-it 122 chemistry, by incubation in EdU working buffer (1.875 $\mu \mathrm{M}$ Alexafluor 488 azide (Invitrogen),

$1232 \mathrm{mM} \mathrm{CuSO}_{4}, 10 \mathrm{mM}$ Ascorbic acid), overnight at $4^{\circ} \mathrm{C}$, prior to processing for 124 immunofluorescence staining.

\section{Organoid Culture}

126 Isolated crypts were dissociated to single cells with TripLE express (Life Technologies) at $12737^{\circ} \mathrm{C}, 5$ minutes. Dissociated cells were filtered through a $40 \mu \mathrm{m}$ cell strainer (Greiner) and 


\section{Delayed activation of the DNA replication licensing system in $\operatorname{Lgr5(+)}$ intestinal stem cells}

128 suspended in growth factor reduced Matrigel (BD Biosciences). Organoids were grown in 129 crypt media (Advanced DMEM/F12 (ADF) supplemented with 10 mM HEPES, 2 mM

130 Glutamax, $1 \mathrm{mM}$ N-Acetylcysteine, N2 (Gemini), B27 (Life technologies), Penicillin/Streptomycin (Sigma) supplemented with growth factors - ENR media (EGF (50

$132 \mathrm{ng} / \mathrm{ml}$, Invitrogen), Noggin (100 ng/ml, eBioscience) and RSpondin conditioned media produced from stably transfected L-cells (1:4). Chiron99021 (3 $\mu \mathrm{M})$, Valproic acid (1 mM, Invitrogen) and Y27632 (10 $\mu \mathrm{M}$, eBiosciences) were added to the culture for the first 48 hours. Organoids were passaged every 3-5 days by mechanically disrupting Matrigel and by washing and pipetting in ADF. Dissociated crypts were re-suspended in fresh Matrigel and

137 grown in crypt media supplemented with growth factors.

138 For small molecule treatments, primary intestinal epithelial cells were cultured in ENR-CVY 139 (ENR plus Chiron99021, Valproic acid and Y27632) for 3 Days, and then organoids were sub140 cultured in ENR for two further days prior to the start of the experiment. Organoids were 141 then treated with the stated small molecules for the indicated time periods. For induction of

142 Unlicensed- $\mathrm{G}_{1}$, organoids were treated with Gefitinib $(5 \mu \mathrm{M})$ coupled with removal of EGF 143 from the crypt media. For re-activation/chase period, the media was removed and fresh 144 growth factors added. All growth factors and inhibitors were replenished every 2 days 145 throughout the experiment.

\section{Flow cytometry and cell sorting}

147 Intestinal crypts were isolated and dissociated to single cells as described above. Isolated 148 cells were filtered through $40 \mu \mathrm{m}$ cell strainers (Greiner). For organoids, following one PBS 149 wash, organoids were dissociated to single cells by incubation in TripLE express for 15 


\section{Delayed activation of the DNA replication licensing system in $\operatorname{Lgr5(+)}$ intestinal stem cells}

150 minutes at room temperature followed by manual disruption by pippetting. Cells were then

151 extracted with CSK buffer for 20 minutes on ice, followed by fixation in 0.5\% PFA (pH7.40,

15215 minutes, room temperature). Cells were then washed once in 1\% BSA and permeabilized with ice-cold 70\% EtOH, 10 minutes. Cells were then washed in 1\% BSA and re-suspended with primary antibodies (Mcm2, 1:500; GFP, 1:500; Ki67, 1:200) diluted in Working buffer (overnight, $4^{\circ} \mathrm{C}$ ). Following two washes in working buffer, cells were re-suspended in secondary antibodies goat anti-mouse or anti-rabbit (Alexafluor647, 1:500 (Molecular Probes); Alexafluor488-Ki67, 1:400 (Clone SolA15, BD Biosciences), diluted in working buffer (1 hour, room temperature). After two washes in 1\% BSA, cells were suspended in working buffer containing $15 \mu \mathrm{g} / \mathrm{ml}$ DAPI. Samples were analysed on a FACS Canto (BD Biosciences).

160 For cell sorting, cells were isolated from Lgr5-GFP mice as described above by treatment 161 with TripLE express for 15 minutes, $37^{\circ} \mathrm{C}$ followed by filtration through $40 \mu \mathrm{m}$ filters

162 (Greiner). Cells were sorted in ADF supplemented with 1\% FBS and DAPI (15 $\mu \mathrm{g} / \mathrm{ml})$. Sorting 163 was performed using an Influx ${ }^{\mathrm{TM}}$ Cell sorter (BD biosciences). Cells were checked post-sort

164 to ensure sample purity by re-examining Lgr5 expression in the sorted gates.

\section{Microscopy and Image analysis}

166 Samples were imaged using a Zeiss LSM 710 microscope using a 40X LD Pan-Neofluar

167 objective lens and immersion oil with a refractive index of 1.514. Z-stacks were acquired at 168 optimal section intervals between 0.3 and $0.8 \mu \mathrm{m}$. For quantification, images were acquired at 16 bit-depth.

171 crypts were manually cropped, ensuring that an individual crypt was the only region of 
bioRxiv preprint doi: https://doi.org/10.1101/177477; this version posted February 14, 2018. The copyright holder for this preprint (which was not certified by peer review) is the author/funder. All rights reserved. No reuse allowed without permission.

\section{Delayed activation of the DNA replication licensing system in $\operatorname{Lgr5(+)}$ intestinal stem cells}

172 interest. All nuclei were detected in individual crypts using automated thresholding in Imaris

173 using the measurement point function, set to detect nuclei at an estimated size of $3.5 \mu \mathrm{m}$.

174 Missed or incorrectly assigned nuclei were manually identified. This function produced

175 measurement points that segmented the specific region at the corresponding co-ordinate of

176 the measurement point. Mean intensities for different channels were calculated per spot.

177 This equates to the intensity at the centre region of each nucleus. A reference nucleus at the

178 crypt base was used to define the crypt base position. The Euclidean distance to this point

179 was measured and defined as the distance to the crypt base. Multiple images were analysed

180 using the same workflow and the analysed files collated. For vibratome sections, a plane

181 was manually defined running through to the muscle layer beneath the epithelium. The

182 smallest distance to this surface was defined for segmented nuclei. For nuclear volume

183 estimation, nuclei were manually segmented in 3D using the manual segmentation tools

184 within Imaris (S1 Figure). 
bioRxiv preprint doi: https://doi.org/10.1101/177477; this version posted February $14,2018$. The copyright holder for this preprint (which was not certified by peer review) is the author/funder. All rights reserved. No reuse allowed without permission.

\section{Delayed activation of the DNA replication licensing system in $\operatorname{Lgr5(+)}$ intestinal stem cells}

186 Flow cytometry data was analysed using FlowJo (Treestar) using a standardised gating

187 strategy (S1 Figure). Briefly, cells were identified using FSC and SSC. Following doublet

188 discrimination, gates were set using appropriate controls lacking conjugated secondary 189 antibodies and without primary antibodies. Mcm2 negative gates were set by secondary 190 only controls in conjunction with the $\mathrm{Mcm} 2$ intensity of $\mathrm{G}_{2}$ cells. $\mathrm{G}_{1}$ cells were discriminated based on the maximal DNA-bound Mcm2 intensity prior S-phase, and by DAPI intensity.

\section{Computational Modelling}

A deterministic computer model for licensing in $\mathrm{G} 1$ was written in the Swift programming language using the Xcode 9 development environment. The model assumes that there is a minimum $\mathrm{G} 1$ period that is required for cells to grow to a critical size before they can enter $\mathrm{S}$ phase. Licensing can take place during this period at a constant rate. A licensing rate of 1 means that cells will be fully licensed in exactly the minimum G1 period. It is also assumed that cells have a robust 'licensing checkpoint' (Shreeram et al., 2002, Blow and Gillespie, 2008) so that they cannot enter S phase until origins have been fully licensed. An optional 'unlicensed G1 period' occurs at the start of G1, during which time no licensing takes place. In the simulation, cells enter G1, wait for any optional 'unlicensed G1 period', then start to license origins at a fixed rate; cells exit G1 and modelling ceases only when they have become maximally licensed and also the minimum G1 period has elapsed. The model divides the minimum G1 period into 10,000 equal steps and records the degree of licensing at the end of each step in the 'Licensing Array'. The contents of the Licensing Array are distributed into 101 different frequency bins, ranging from $0 \%$ (no licensing) to 100\% (maximal 
bioRxiv preprint doi: https://doi.org/10.1101/177477; this version posted February 14, 2018. The copyright holder for this preprint (which

was not certified by peer review) is the author/funder. All rights reserved. No reuse allowed without permission.

\section{Delayed activation of the DNA replication licensing system in $\operatorname{Lgr5}(+)$ intestinal stem cells}

/I

// JBLicensingRateModel.swift version 1.0

II

// Created by Julian Blow on 05/10/2017.

import Foundation

class JBLicensingRateModel \{

let licensingRate: Double // rate of licensing in proportion to minimum G1 length

let proportionUnlicensedG1: Double // proportion of minimum $\mathrm{G} 1$ before licensing occurs

let timeStepsForMinimumG1: Int

let licensingPerStep: Double

let timeStepsBeforeLicensingStarts: Int

let binsForFACS: Int

let backgroundForFACS: Double

let binSmoothingProportion: Double

let totalNumberOfCells: Double

let precisionCutOffForSmoothing: Double

let numberOfTimepointsOutput: Int

init (licensingRate: Double, proportionUnlicensedG1: Double) \{ self.licensingRate $=$ licensingRate

self.proportionUnlicensedG1 $=$ proportionUnlicensedG1

timeStepsForMinimumG1 $=10000$

licensingPerStep $=($ licensingRate $/$ Double $($ timeStepsForMinimumG1 $)) * 100$

timeStepsBeforeLicensingStarts $=\operatorname{Int}\left(\right.$ proportionUnlicensedG1 ${ }^{*}$ Double(timeStepsForMinimumG1)

binsForFACS $=100$

backgroundForFACS $=5$

binSmoothingProportion $=0.8$

totalNumberOfCells $=10000.0$

precisionCutOffForSmoothing = totalNumberOfCells $/ 10000$ // cutoff for the smallest number of cells we continue to smooth for the far right of the array

numberOfTimepointsOutput $=100$

\}

func run ()$->$ ([Double], [Double]) \{

var licensingTimepoints: [Double]

if licensingRate $>0\{$ licensingTimepoints $=$ simulateLicensing() $\}$

else $\{$ licensingTimepoints = Array (repeating: 0.0, count: timeStepsForMinimumG1) $\} \quad / /$ if licensing can never occur let FACSOutputExact = simulateFACSExact(licensingTimepoints: licensingTimepoints)

let FACSOutput $=$ smoothFACSOutput(FACSOutputExact: FACSOutputExact)

var simplifiedLicensingTimepoints $=[$ Double $]()$

for index in stride(from: 0, to: licensingTimepoints.count, by: licensingTimepoints.count/numberOfTimepointsOutput) \{ \} simplifiedLicensingTimepoints.append(licensingTimepoints[index])

\}

return (FACSOutput, simplifiedLicensingTimepoints)

func simulateLicensing() -> [Double] \{

// simulates the degree of MCM loading given the licensingRate and proportionUnlicensed

// returns amount of MCM loaded (percent max) at different time points

var amountOfLicensing $=0.0$

var licensingArray = Array(repeating: 0.0, count: timeStepsBeforeLicensingStarts)

var timeStep $=$ timeStepsBeforeLicensingStarts

repeat \{

amountOfLicensing $+=$ licensingPerStep

if amountOfLicensing $>100\{$ amountOfLicensing $=100\}$

licensingArray.append(amountOfLicensing) 
bioRxiv preprint doi: https://doi.org/10.1101/177477; this version posted February 14, 2018. The copyright holder for this preprint (which

was not certified by peer review) is the author/funder. All rights reserved. No reuse allowed without permission.

\section{Delayed activation of the DNA replication licensing system in Lgr5(+) intestinal stem cells}

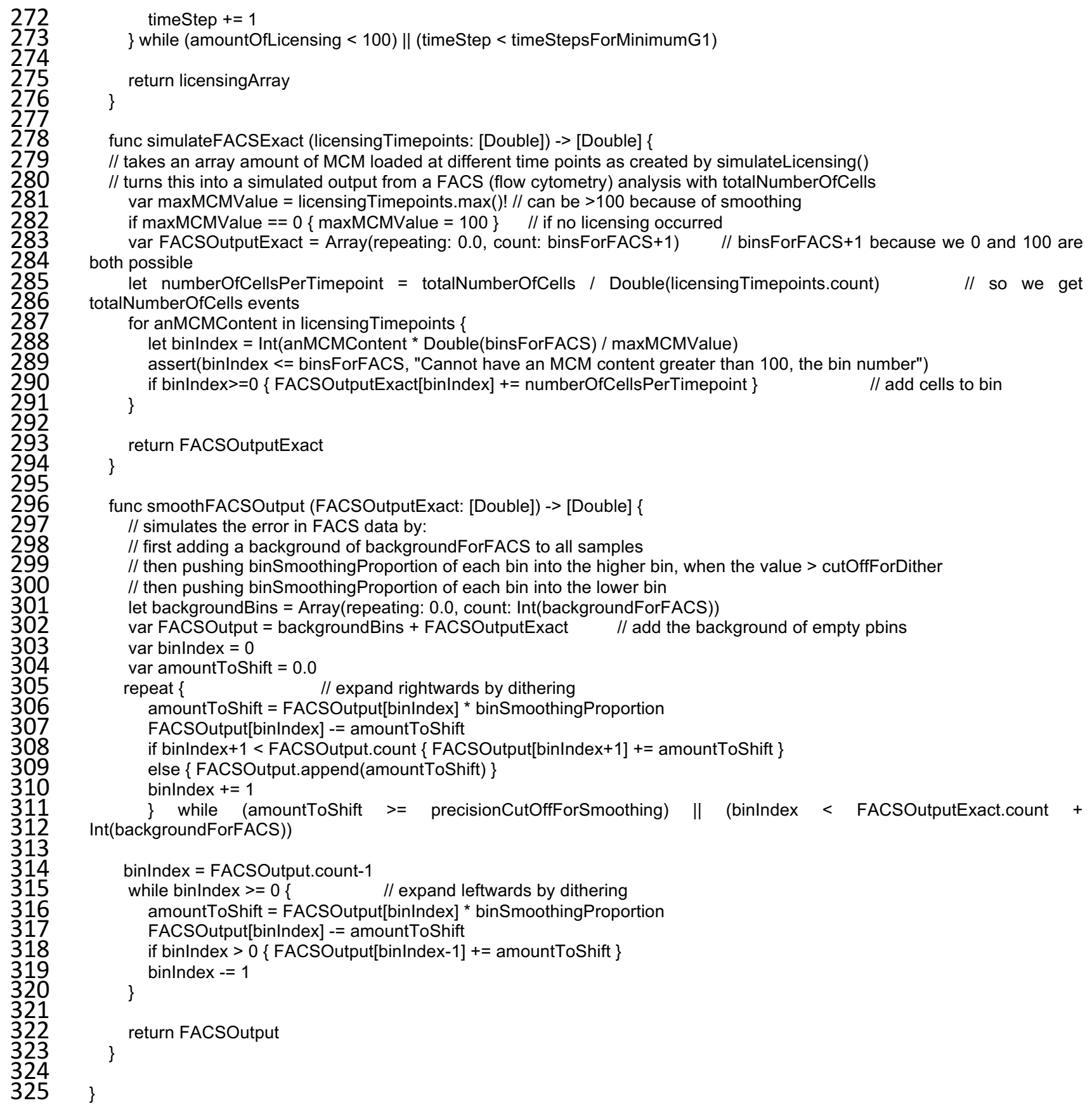

RESULTS

327 Mcm2 expression declines along the crypt-villus axis

328 Because of their abundance, strong conservation and association with the core DNA 329 replication process, the presence of $\mathrm{MCM} 2-7$ proteins is commonly used to establish 330 proliferative capacity in tissues, similar to Ki67 or PCNA (Gonzalez et al., 2005, Jurikova et 


\section{Delayed activation of the DNA replication licensing system in $\operatorname{Lgr5(+)}$ intestinal stem cells}

331 al., 2016, Stoeber et al., 2001, Williams et al., 1998). Usually, terminally differentiated cells

332 in mammalian tissues do not contain MCM2-7 (Stoeber et al., 2001, Todorov et al., 1998,

333 Eward et al., 2004). To establish the overall MCM2-7 protein abundance along intestinal crypts, we first examined the expression of MCM2-7 proteins in adult murine smallintestinal epithelium using high-resolution immunofluorescence microscopy. We focused on

Mcm2 as a surrogate for all the members of the MCM2-7 complex based on their similar

function and localisation. However, we repeated a subset of the experiments using an antibody to Mcm4, which is less effective in detecting endogenous proteins. Nonetheless, in all cases, the results were identical.

340 Consistent with previous reports, $\mathrm{Mcm} 2$ was highly expressed in both murine and human

341 intestinal epithelium. Mcm2 was highly expressed in intestinal crypts (Figure 1A) and declined gradually along the crypt-villus axis (Figure 1B), but persisted in a few cells in the villus compartment (Figure 1D). Mcm2 was nuclear in interphase cells but cytoplasmic during mitosis (Figure 1C). Although the majority of intestinal crypt cells expressed Mcm2, at the crypt base, Mcm2(+) and Mcm2(-) cells were interspersed (Figure 1A, D), consistent with previous reports (Pruitt et al., 2010). This pattern is reminiscent of the alternating arrangement of $\operatorname{Lgr5(+)}$ stem cells and Paneth cells at the crypt base (Barker et al., 2007). Lgr5(+) stem cells express Ki67 and are continually proliferative whereas Paneth cells are fully differentiated and are Ki67(-) (Basak et al., 2014). As expected, Mcm2 was expressed in all Lgr5(+) stem cells and there was a strong correlation between Mcm2 and Lgr5 expression

351 (Figure 1E). This is consistent with the idea that $\mathrm{Lgr}^{\mathrm{Hi}}$ stem cells are the main proliferative

352 stem cells in the intestinal crypt. Staining with Ulex Europaeus Agglutinin I (UEA), 


\section{Delayed activation of the DNA replication licensing system in $\operatorname{Lgr5(+)}$ intestinal stem cells}

354 Normally, MCM2-7 expression is lost in terminally differentiated cells (Eward et al., 2004,

355 Stoeber et al., 2001, Williams et al., 1998, Williams et al., 2004). The loss of expression has

356 been suggested as a major contributor to the proliferation-differentiated switch in vivo. To

357 test this idea, we measured the $\mathrm{Mcm} 2$ content of young and mature secretory cells in

358 intestinal crypts and villi (Figure 1G, H). There was differential expression of Mcm2 in 359 distinct secretory lineages. Many mature secretory cells including Paneth, Goblet and 360 enteroendocrine cells were $\mathrm{Mcm} 2(-)$, consistent with their differentiation status and long

361 life-span in the epithelium (van der Flier and Clevers, 2009). We detected a small number of 362 UEA(+) Mcm2(+) cells in intestinal crypts (Figure 1G). Assuming that Mcm2 expression 363 declines slowly after terminal differentiation, the presence of $M c m 2$ in UEA(+) secretory 364 cells could reflect their immaturity. Consistently, Mcm2 expression in UEA(+) cells in crypts 365 was significantly higher than in villi (Figure $\mathbf{1 H}$ ), supporting the idea that MCM2-7 are 366 gradually lost upon terminal differentiation. Since MCM2-7 are highly abundant and have a 367 long (>24 hour) half-life (Musahl et al., 1998), it likely that after cells differentiate, their MCM2-7 content declines at a slow rate, explaining why $\mathrm{Mcm} 2$ persists in the villus compartment.

\section{Visualisation of DNA replication licensing In vivo}

371 MCM2-7 exist in three states: as hexamers free in the nucleoplasm, as double hexamers

372 bound to DNA during late mitosis, G1 and S phase, or as CMG complexes at replication forks

373 during S phase (Evrin et al., 2009, Gambus et al., 2011, Remus et al., 2009). To distinguish

374 between DNA-bound and soluble forms, we developed a protocol involving a brief

375 extraction of isolated crypts with non-ionic detergent to remove soluble MCM2-7. The 


\section{Delayed activation of the DNA replication licensing system in $\operatorname{Lgr5(+)}$ intestinal stem cells}

remaining Mcm2 should mark cells whose origins are licensed for replication. Extraction did not visibly affect intestinal crypt integrity but made them more opaque compared to unextracted tissue (Figure 2A). The majority of cells in unextracted crypts were $\mathrm{Mcm} 2(+)$ (Figure 2B, 'Total') similar to tissue sections and mirroring the ubiquitous expression of Ki67 along the crypt axis. After extraction, the majority of the $\mathrm{Mcm} 2$ content in cells was lost (Figure 2B, 'Licensed'), with only $10-30 \%$ of cells maintaining high levels of $\mathrm{Mcm} 2$ (Figure 2C). After extraction, Mcm2(+) was not present in mitotic cells expressing phosphorylated histone $\mathrm{H} 3$, confirming the extraction procedure successfully removed non-DNA bound MCM2-7 proteins (Figure 2D).

We used flow cytometry to measure MCM2-7 content more directly and further confirm the effectiveness of the extraction procedure. Whereas the majority of isolated epithelial cells expressed $\mathrm{Mcm} 2$ that persisted throughout the cell-cycle, extraction revealed a distinct profile of Mcm-containing cells in crypts (Figure 2E). These profiles are consistent with those reported for cultured cell lines (Friedrich et al., 2005, Haland et al., 2015, Moreno et al., 2016, Matson et al., 2017). Mcm2 is present throughout the cell cycle (Figure 2E, 'Unextracted'), but extraction shows that it binds to DNA throughout $G_{1}$, reaching a maximum level before cells enter S-phase, and is subsequently displaced from DNA during S phase. This behaviour, which matches the known cell cycle behaviour of MCM2-7, confirms the efficiency of our extraction protocol. An antibody against Mcm4 produced similar results (data not shown). We observed that the majority of cells with a G1 DNA content appeared to be unlicensed, having a DNA-bound $\mathrm{Mcm} 2$ content similar to $\mathrm{G}_{2} / \mathrm{M}$ cells (Figure $\mathbf{2 E}, \mathrm{E}^{\prime}$ ). This is substantially different from typical profiles observed in cultured cells lines in which most $\mathrm{G}_{1}$ cells are fully licensed (Friedrich et al., 2005, Haland et al., 2015, Moreno et al., 
bioRxiv preprint doi: https://doi.org/10.1101/177477; this version posted February 14, 2018. The copyright holder for this preprint (which was not certified by peer review) is the author/funder. All rights reserved. No reuse allowed without permission.

\section{Delayed activation of the DNA replication licensing system in $\operatorname{Lgr5(+)}$ intestinal stem cells}

2016, Matson et al., 2017). Similar results were observed in cells isolated from intestinal organoids (Figure $\mathbf{2 F}, \mathbf{G}$ ).

Licensing status and cell-cycle progression along the crypt-villus axis

402 Cell-cycle dynamics of intestinal stem and progenitor cells are highly heterogeneous (Pruitt 403 et al., 2010). The majority of $\operatorname{Lgr} 5(+)$ stem cells are considered to be continually 404 proliferative, but with a much longer cell-cycle than transit-amplifying progenitor cells, 405 which are most commonly found in S-phase (Schepers et al., 2011). To investigate proliferative fate decisions of intestinal epithelial cells, we used our MCM2-7 extraction in crypts where S phase cells were labelled in vivo with the nucleoside analogue EdU. We then used image analysis software to correlate $\mathrm{Mcm} 2$ content with cell-cycle stage along the crypt-villus axis (S1 Figure A-F). This allowed quantification of licensing in relation to the cell-cycle and 3D spatial information.

Figure $3 \mathrm{~A}$ shows tissue labelled in vivo with a 1 hour EdU pulse followed by extraction of soluble MCM2-7. As expected, the majority of cells in the transit-amplifying compartment were labelled with EdU suggesting that most cells were in S-phase, consistent with early 414 studies using BrdU and $\left[{ }^{3} \mathrm{H}\right]$-thymidine labelling (Chwalinski and Potten, 1987). The patterns of replication foci were consistent with the reported S-phase replication timing programme

416 (Rhind and Gilbert, 2013). Typically, all licensed cells had intense nuclear Mcm2 staining.

417 Some cells completely lacked $\mathrm{Mcm} 2$ and EdU labelling, suggesting they were in either $\mathrm{G}_{0}$, 418 very early $G_{1}$ or in $G_{2}$. Some cells were labelled with both $\mathrm{Mcm} 2$ and $E d U$. These double419 labelled cells typically showed patterns of EdU labelling consistent with early to mid S phase and $\mathrm{Mcm} 2$ labelling of DNA compartments expected to replicate later in S phase. This 


\section{Delayed activation of the DNA replication licensing system in $\operatorname{Lgr5(+)}$ intestinal stem cells}

421 relationship has been observed in tissue culture cells (Krude et al., 1996) and is consistent

422 with the idea that DNA-bound MCM2-7 are displaced from chromosomal domains as

423 replication is completed. Cells with late S-phase patterns of EdU labelling had little or no 424 detectable $\mathrm{Mcm} 2$, consistent with the displacement of the majority of MCM2-7 by the end 425 of S phase. We also measured nuclear volume, which increases during $\mathrm{S}$ phase and $\mathrm{G}_{2}$. This 426 showed that nuclear volume increased up to two-fold in cells classified as S-phase and Late$427 \mathrm{~S} / \mathrm{G}_{2}$ by $\mathrm{Mcm} 2$ and EdU staining (Figure 3B). This confirms our cell-cycle assignment and also 428 suggests that most $M c m 2(-)$ cells are in $G_{0}$ or $G_{1}$, rather than in $G_{2}$.

429 The combination of concurrently labelling DNA-bound Mcm2 and EdU showed a clear correlation between cell position and cell-cycle stage. As noted previously, $\mathrm{Mcm} 2$ is expressed in cells throughout the crypt (Figure 3C, D). At the base of the crypt, unlicensed cells predominate (Figure $\mathbf{3 C}, \mathbf{E}$ ). At increasing distances from the crypt base there is a successive rise in licensed $G_{1}$ cells, early/mid $S$ phase cells and then late $S / G_{2}$ cells. Further up the crypt, at the end of the TA compartment, these cell cycle stages decline in reverse order, until unlicensed cells again predominate. This suggests that there is a co-ordinated progression through the cell division cycle as cells enter, then leave, the TA compartment. This was also observed as a field effect with many neighbouring cells showing similar replication patterns (S2 Figure A, B; S1 Movie).

440 At the terminal boundary of the transit-amplifying compartment, the majority of cells were

441 unlicensed and had no DNA-bound Mcm2 (Figure 3C, E). Similarly, there were no licensed $\mathrm{G}_{1}$

442 cells beyond the TA compartment as defined by incorporation of EdU (Figure 3F). However, 
bioRxiv preprint doi: https://doi.org/10.1101/177477; this version posted February 14, 2018. The copyright holder for this preprint (which was not certified by peer review) is the author/funder. All rights reserved. No reuse allowed without permission.

\section{Delayed activation of the DNA replication licensing system in $\operatorname{Lgr5(+)}$ intestinal stem cells}

443 total Mcm2 expression extended significantly beyond the last cells with DNA-bound Mcm2

444 or incorporated EdU (Figure 3C, D, F). The distribution of total Mcm2 expression

445 corresponded to the zone where cells express Ki67 (S3 Figure). Although Mcm2 and Ki67

446 expression persists beyond the TA compartment, licensing does not occur in this area. This

447 suggests that differentiation is not governed by a gradual reduction in total MCM2-7 levels,

448 but is a binary decision and licensing is abolished immediately after the final mitosis

449 preceding differentiation. To further examine this, we marked the terminally differentiated

450 zone by a 1 hour EdU pulse, followed by a 16 hour chase (Figure 3G, H). After 16 hours, the

451 majority of the distal end of the TA compartment became labelled with EdU. All labelled

452 nuclei in this area were significantly smaller than $\operatorname{EdU}(+)$ cells at the proximal end of the TA

453 compartment (data not shown), suggestive of their differentiation status. Importantly the

$454 \mathrm{EdU}(+)$ differentiated cells at the distal end of the TA compartment lacked DNA-bound 455 Mcm2, supporting our suggestion that licensing is inhibited immediately at terminal 456 differentiation.

\section{The majority of Intestinal stem cells spend the majority of $\mathbf{G}_{1}$ in an unlicensed state}

458 The majority of cells in the crypt base expressed $\mathrm{Mcm} 2$, consistent with the finding that all 459 Lgr5(+) cells express Mcm2 but mature secretory cells, such as Paneth cells, do not (Figure 460 1D, E). Surprisingly, extraction revealed that only $7-15 \%$ of cells were licensed in the crypt 461 base (Figure 3C, D), with most cells in an unlicensed state despite expressing Mcm2. The 462 abundance of licensed cells peaked 40-60 $\mu \mathrm{m}$ away from the crypt base, corresponding to 463 just above the $+4 /+5$ cell position (Figure 3D, E). This suggests that the majority of stem cells 


\section{Delayed activation of the DNA replication licensing system in $\operatorname{Lgr5(+)}$ intestinal stem cells}

464

465

466

467

468

469

470

471

472

473

474

475

476

477

478

479

480

481

482

483

484

485

486

remain unlicensed. In contrast, the majority TA cells appear to progress rapidly through the cell-cycle, as many more actively incorporate EdU (Figure 4A).

We next confirmed that the unlicensed cells at the crypt base were Lgr5(+) stem cells. As it is not possible to identify Lgr5 in these experiments, as it is extracted along with unbound Mcm2, we instead identified Paneth cells by UEA staining and considered all UEA(-) cells in the crypt base to stem cells (Figure 4B). $>50 \%$ of the UEA(-) stem cells were in an unlicensed state and were not incorporating EdU (Figure 4C). Approximately $30-40 \%$ of all UEA(-) cells in the stem cell compartment were in an active phase of the cell cycle (licensed $\mathrm{G}_{1}, \mathrm{~S}$ or $\mathrm{G}_{2}$;

Figure 4C), corresponding to 5-6 stem cells out of the total 14 present (Snippert et al., 2010). This number is similar to the small number of proposed 'working' stem cells in the crypt base (Baker et al., 2014, Kozar et al., 2013). Unlicensed cells not incorporating EdU (i.e. unlabelled in this experiment) could theoretically be in either $G_{0}$ or in $G_{2}$. To distinguish between these possibilities we first isolated crypt cells from Lgr5-GFP mice and measured both GFP and DNA content. Both Lgr5(+) and Lgr5(-) cell populations had a similar cell-cycle profile with the majority of cells having 2N DNA content (S2 Figure C). We also examined the nuclear volume of cells at different positions along the crypt axis, after staining for EdU incorporation and DNA-bound Mcm2. The majority of unlicensed cells had a similar nuclear volume to that of fully licensed cells in $G_{1}$ and not cells in Late- $S / G_{2}$ phase (S2 Figure D). Together, these results suggest that, although they express abundant Mcm2, the majority of intestinal stem cells reside in an unlicensed $\mathrm{G}_{1}$ state.

To confirm this conclusion, we flow-sorted unextracted Lgr5-GFP(+) cells, extracted unbound MCM2-7 and stained them for Mcm2 and Ki67. Consistent with our previous results, most $\operatorname{Lgr} 5(+)$ cells with a $2 \mathrm{~N}$ DNA content had low levels of DNA-bound Mcm2, and 


\section{Delayed activation of the DNA replication licensing system in $\operatorname{Lgr5(+)}$ intestinal stem cells}

487 were in an unlicensed state (Figure 4Di, ii). Importantly, both the licensed and unlicensed cells were $\mathrm{Ki67(+)}$ indicating that they had not withdrawn from the cell-cycle long-term

(Figure 4Dii).

This unlicensed $G_{1}$ state - 2N DNA content, high $\mathrm{Mcm} 2$ expression but with low levels of

DNA-bound Mcm2 - could be explained by two, slightly different, scenarios. 1) MCM2-7 are

loaded on to DNA slowly in Lgr5(+) cells, thereby extending $G_{1}$ (Schepers et al., 2011)

(Dalton, 2015); or 2) Most $\operatorname{Lgr5}(+)$ cells enter $\mathrm{G}_{1}$ and remain in an unlicensed state but do not load MCM2-7 until an active decision is made to commit to cell cycle progression and activate the licensing system, at which time MCM2-7 proteins are rapidly loaded. In option

where licensing does not occur, there should be a discrete peak of unlicensed cells with a $\mathrm{G}_{1}$

DNA content representing cells that have withdrawn from the cell cycle, and a lower

501 frequency of $G_{1}$ cells that have loaded different amounts of MCM2-7. To distinguish between these two possibilities, we utilized ergodic rate analysis. When examining the 


\section{Delayed activation of the DNA replication licensing system in $\operatorname{Lgr5(+)}$ intestinal stem cells}

510 appeared, similar to what has been observed in cell lines. Only when an unlicensed G1

511 period was introduced did a distinct peak of unlicensed G1 cells appear (Figure 4F, left hand

512 panels). Since most of these unlicensed Lgr5(+) cells express abundant Mcm2 (Figure 1D),

513 this suggests that their $G_{1}$ is characterised by a long unlicensed period. This may explain why

514 the cell-cycle length of intestinal stem cells is significantly longer than transit-amplifying

515 cells (Schepers et al., 2011).

516 To further confirm that many intestinal stem cells exist in an unlicensed $G_{1}$ state, we

517 examined the expression of Fluorescence ubiquitination cell-cycle indicator (FUCCI)

518 reporters as an independent indicator of cell-cycle progression. We harvested intestinal

519 tissue from Fucci2aR mice (Mort et al., 2014), and examined the expression of the $\mathrm{G}_{1}$

520 specific $h C d t 1(30 / 120)$ and $S / G_{2} / M$ specific hGeminin(1/110) reporters (S4 Figure A). As

521 expected, many TA cells were hGeminin $(1 / 110)(+)$. We also noticed that terminally

522 differentiated cells, such as Paneth cells in the stem cell compartment, and cells at the tips

523 of villi expressed high levels of hCdt1(30/120) (S4 Figure B) reflecting accumulation of the

524 reporter in differentiated cells (Mort et al., 2014). However, we found that most Mcm2(+)

525 stem cells in the crypt base expressed very low levels of the hCdt1(30/120) reporter, and

526 only few cells expressed high levels (S4 Figure C, D). In contrast, the majority of TA cells

527 were either hGeminin(1/110 $)^{\text {High }}$ or $\mathrm{hCdt1}(30 / 120)^{\text {low }}$, consistent with a short $\mathrm{G}_{1}$ phase.

528 Together, this suggests that stem cells remain in a paused unlicensed $\mathrm{G}_{1}$ state where they

529 do not rapidly accumulate hCdt1(30/120) unlike rapidly proliferating cells.

530 It has previously been reported that embryonic stem cells license more replication origins

531 than neural stem/progenitor cells differentiated from them (Ge et al., 2015). To determine if

532 adult stem and non-stem cells in intestinal crypts exhibit such differences, we compared the 
bioRxiv preprint doi: https://doi.org/10.1101/177477; this version posted February 14,2018 . The copyright holder for this preprint (which was not certified by peer review) is the author/funder. All rights reserved. No reuse allowed without permission.

\section{Delayed activation of the DNA replication licensing system in $\operatorname{Lgr5(+)}$ intestinal stem cells}

533 amount of DNA-bound $M c m 2$ in $G_{1} / G_{0}$ and early $S$ phase $\operatorname{Lgr} 5(+)$ cells with that in $\operatorname{Lgr5}(-)$

534 cells (Moreno et al., 2016). Although the majority of $\operatorname{Lgr5}(+)$ cells were unlicensed, when

535 they entered S phase they had approximately twice as much DNA-bound Mcm2 compared

536 to Lgr5(-) cells (Figure 4G). This is consistent with the idea that adult intestinal stem cells

537 license more origins than TA cells and may represent a mechanism to protect genomic 538 integrity.

\section{Intestinal label retaining cells are in a deep $\mathbf{G}_{0}$ state}

540 Although the intestinal crypt base primarily consists of $\operatorname{Lgr5}(+)$ stem cells there is also a

541 reserved pool of quiescent stem cells, often referred to as ' +4 label retaining cells' (LRCs)

542 reflecting their position in the crypt base and their ability to retain nascent DNA labels

543 (Potten et al., 2002). These cells are a rare subset of Lgr5(+) cells and are also secretory 544 precursors (Buczacki et al., 2013). To further define the licensing status of these label-

545 retaining intestinal stem cells, we identified UEA(-) LRCs by expressing H2B-GFP (which is 546 incorporated into the chromatin of dividing cells) for 7 days and then chasing for a further 7

547 days (Buczacki et al., 2013, Roth et al., 2012). Labelled cells that did not divide during the 7-

548 day chase period contain high levels of H2B-GFP (hence are LRCs), but cells that divided

549 multiple times only have low levels. LRCs were then distinguished from Paneth cells based

550 on UEA staining (Figure 5A). After induction, most cells in the epithelium expressed H2B-

551 GFP (Figure 5Bi). After the 7D chase, H2B-GFP expression was restricted to cells near the

552 villus tips, and cells at the crypt base (Figure 5Bii). We could successfully distinguish

553 between Paneth cells and LRCs on the basis of UEA staining (Figure 5Bii). Unlike the majority

554 of the Lgr5(+) cells, LRCs with high GFP-H2B did not express Mcm2 (Figure 5C). As expected, 
bioRxiv preprint doi: https://doi.org/10.1101/177477; this version posted February 14, 2018. The copyright holder for this preprint (which was not certified by peer review) is the author/funder. All rights reserved. No reuse allowed without permission.

\section{Delayed activation of the DNA replication licensing system in $\operatorname{Lgr5(+)}$ intestinal stem cells}

555

556

557

558

559

560

561

562

563

564

565

566

567

568

569

570

571

572

only non-LRC daughter cells with low levels of H2B-GFP had DNA-bound Mcm2 (Figure 5D).

This shows that, LRC stem cells are in deep $G_{0}$, unable to license because they do not express MCM2-7. In contrast, 'active' intestinal stem cells mostly reside in an unlicensed $\mathrm{G}_{1}$ state.

\section{Licensing dynamics in intestinal organoids}

Intestinal stem cells reside in a highly specialised niche at the base of crypts. It is therefore possible that this niche specifically allows stem cells to pause in an unlicensed $G_{1}$ state where origin licensing is prevented until a further proliferative fate signal is received. To understand the contribution of the stem cell niche to the dynamics of entry and exit from the unlicensed $\mathrm{G}_{1}$ state, we used intestinal organoids, which allowed us to manipulate the stem cell niche/environment with small-molecules. Although the distribution of licensed cells was similar between the branches of intestinal organoids and crypts in tissue, there were considerably more cells with DNA-bound Mcm2 in the former (Figure 6A, Ciii). Importantly, cells in organoids showed a discrete peak of fully licensed $\mathrm{G}_{1}$ cells in addition to the cells in the unlicensed $G_{1}$ state (Figure $6 \mathrm{Bii}$ ). This suggests that the epithelium in organoids represents an accelerated state of self-renewal and may not fully recapitulate cell-cycle dynamics of intestinal epithelial cells in vivo.

We designed an assay to robustly assess licensing dynamics during entry and exit from the unlicensed $G_{1}$ state, and transition towards $G_{0}$. Specifically, we used flow cytometry based quantification of DNA-bound Mcm2, Ki67 and DNA content to measure licensing dynamics during entry and exit from the unlicensed $G_{1}$ state, and transition towards $G_{0}$ (S5 figure A). Most cells in organoids express Ki67 and it increased during cell-cycle progression (Figure 


\section{Delayed activation of the DNA replication licensing system in $\operatorname{Lgr5(+)}$ intestinal stem cells}

577 6Bi). The DNA-bound $\mathrm{Mcm} 2$ profile was similar to that in isolated crypts (Figure 6Bii).

578 Correlating Ki67 and DNA-bound Mcm2 produced a distinctive profile that is similar for

579 isolated cells from organoids (Figure 6Ci) and intestinal crypts (Figure 6Cii). This profile

580 reveals a population of cells that appear to lose Ki67 (dashed arrow in Figure 6Cii) and may

581 represent cells decreasing in proliferative capacity and transitioning towards differentiation

582 (S5 Figure A). Such a loss of proliferative capacity appeared to initiate in cells that express

583 Ki67 but are unlicensed, i.e. cells in unlicensed $\mathrm{G}_{1}$. These data suggest that different stages

584 of quiescence can exist that reflected by a spectrum of Ki67 and Mcm levels.

585 Stem-cell niche maintenance in organoids mainly depends on a combination of EGF, Wnt

586 and Notch signalling (Sato et al., 2011). To identify the pathway that can modulate the

587 unlicensed $G_{1}$ state, we systematically treated organoids with a small molecule inhibitor of

588 EGFR (Gefitinib), a Wnt agonist (Chir99021), and a Notch activator (Valproic acid). Short-

589 term treatment with Gefitinib, which reduces MAP kinase activity and blocks DNA

590 replication and cell division (Lynch et al., 2004), immediately caused cells to accumulate in

591 the unlicensed $\mathrm{G}_{1}$ state, with a $2 \mathrm{~N}$ DNA content but continuing to express $\mathrm{Mcm} 2$ and Ki67

592 (Figure 6D, E). Only prolonged EGFR inhibition (4 days) caused transition to an intermediate

$593 \mathrm{G}_{0}$ state, with significantly reduced Ki67 expression but with total Mcm2 levels maintained

594 (Figure 6D, E). Both states were reversed by removal of EGFRi and addition of fresh growth

595 factors (Figure 6D, E). Previously it was shown that EGFR increases Lgr5 expression (Basak et

596 al., 2017), suggesting that these transitional states (Unlicensed $G_{1}$ and $G_{0}$ ) are associated

597 with 'stemness'. Additionally, EGFRi appeared to potently kill transit-amplifying cells (S5

598 Figure B, C), leaving branches containing only stem cells (Basak et al., 2017). This suggests 


\section{Delayed activation of the DNA replication licensing system in $\operatorname{Lgr5(+)}$ intestinal stem cells}

599 that both, the fully quiescent $\mathrm{G}_{0}$ and unlicensed $\mathrm{G}_{1}$ states, may provide protection to stem 600 cells.

601 Treatment with the Wnt agonist Chir99021 did not appear to significantly affect licensing

602 dynamics (S5 Figure C). Strikingly, treatment with the Valproic acid (a Notch activator) alone 603 or in combination with Chir99021 significantly altered licensing profiles (S5 Figure D, F). The 604 combination of Chir99021 and Valproic acid induces Lgr5 expression throughout the 605 organoid epithelium (S5 Figure E) (Yin et al., 2014). Our data showed that this is associated 606 with the appearance of a population of cells with low levels of Ki67 and intermediate levels 607 of DNA-bound Mcm2 (S5 Figure D) similar to the intermediate, shallow $\mathrm{G}_{0}$ state induced by 608 EGFRi. Surprisingly, we observed an arc of cells connecting this to the fully licensed state, 609 suggesting that re-licensing of these cells occurs before they express high levels of Ki67 and 610 that cells can reactivate licensing from a deeper state of $\mathrm{G}_{0}$ directly (S5 Figure D, F).

611 Inhibiting Notch signalling with DAPT, which induces terminal secretory cell differentiation 612 (van Es et al., 2005), also significantly altered licensing dynamics and induced deep $\mathrm{G}_{0}$, with 613 reduced Ki67 and loss of $\mathbf{M c m} 2$ proteins (S5 Figure G). Together, these data suggest that 614 both EGFR signalling and Notch signalling can significantly influence the licensing dynamics 615 during the transition between quiescence and unlicensed $\mathrm{G}_{1}$.

\section{The Unlicensed-( $\mathbf{G}_{1}$ state is lost in Apc mutant organoids}

617 Many established cell lines appear to lack an unlicensed $\mathrm{G}_{1}$ state, instead licensing all origins 618 immediately upon mitotic exit (Friedrich et al., 2005, Haland et al., 2015, Moreno et al., 619 2016, Matson et al., 2017). In addition, many of these cell-lines lack a functional licensing 620 checkpoint (Shreeram et al., 2002, Feng et al., 2003, Liu et al., 2009, Nevis et al., 2009) that 


\section{Delayed activation of the DNA replication licensing system in $\operatorname{Lgr5}(+)$ intestinal stem cells}

621 has been suggested to arrest cells in $G_{1}$ by inactivation of the RB-E2F restriction point(Liu et

622 al., 2009, Machida et al., 2005, Nevis et al., 2009, Shreeram et al., 2002, Teer et al., 2006).

623 To understand the biological relevance of the unlicensed $\mathrm{G}_{1}$ state, we determined whether

624 origin licensing dynamics during $\mathrm{G}_{1}$ are altered during the initial stages of tumorigenesis.

The first initiating mutations in colorectal cancer are usually in Adenomatus polyposis coli (Apc). Therefore, we investigated whether licensing dynamics are altered in Apc mutant intestinal epithelium. In $\mathrm{Apc}^{\mathrm{Min} /+}$ epithelium in vivo, $\mathrm{Mcm} 2$ expression appeared normal in areas of normal histology but was greatly increased in polyps (Figure 7A). In isolated $\mathrm{Apc}^{\mathrm{Min} /+}$ crypts, there was a slight increase in the size of the proliferative compartment similar to previous reports (Trani et al., 2014), and a slight increase in the number of EdU(+) cells in the stem cell compartment (Figure $\mathbf{7 B i}$, iii). However, in the majority of crypts there were no significant differences in the number or distribution of licenced cells in the stem cell compartment (Figure 7Bi, iii). However, we found a small number of crypts that were considerably larger. Strikingly, within these crypts, we noticed small 'ribbons' of EdU(+) cells that extended significantly into the transit-amplifying compartment (Figure 7Bii). We suspected that these ribbons reflected a clone of cells that had undergone loss of heterozygosity $(\mathrm{LOH})$, and continually re-engage with the cell cycle. This in turn suggests

638 that the $\mathrm{LOH}$ event that converts $\mathrm{Apc}^{\mathrm{Min} /+}$ to $A p c^{\mathrm{Min} / \mathrm{Min}}$ cells significantly alters cell-cycle 639 dynamics.

640 To determine whether LOH alters origin licensing dynamics by modifying $\mathrm{G}_{1}$, we compared 641 wild-type and $A p c^{\text {Min/Min }}$ organoids (Figure 7C). Apc ${ }^{\text {Min/Min }}$ organoids contained many more 642 licensed cells that were distributed randomly throughout the organoid (Figure 7D), 643 reminiscent of the altered distribution of Ki67 (+) cells in these organoids (Fatehullah et al., 


\section{Delayed activation of the DNA replication licensing system in $\operatorname{Lgr5(+)}$ intestinal stem cells}

644 2013). Strikingly, we found that licensing dynamics in the $\mathrm{G}_{1}$ phase of $A p c^{\mathrm{Min} / \mathrm{Min}}$ cells were

645 significantly different and there was a significant loss of the unlicensed $\mathrm{G}_{1}$ population.

646 (Figure 7E). Instead, there was a significant population of cells that appear to license

647 immediately upon $\mathrm{G}_{1}$ entry and progressed into S-phase immediately after minimal licensing

648 (Figure 7E, F). Interestingly, we still detected a population of cells that licensed as many 649 origins as in WT organoids. These may be $A p c^{\mathrm{Min} /+}$ cells that had not undergone LOH yet and 650 thus maintained near-normal cell cycle dynamics.

651 A functional licensing checkpoint depends on an intact RB restriction point and we tested 652 whether there the relative amounts of hypo- and hyper-phosphorylated RB varied between 653 wild type and $A p c^{\mathrm{Min} / \mathrm{Min}}$ epithelia. In wild-type organoids, we noticed that the majority of RB 654 appeared hypo-phosphorylated (Figure 7G). In contrast, in $A p c^{\mathrm{Min} / \text { Min }}$ organoids, at least half 655 of RB appeared hyper-phosphorylated, with at least 3-fold more phosphorylated RB.

656 Together, this data is consistent with the idea that cells exist in an unlicensed $\mathrm{G}_{1}$ state prior 657 to passage through the restriction point and activation of E2F-driven transcription. In 658 contrast, Apc mutant cells appear to have lost normal restriction point control, so that they 659 have constitutively hyper-phosphorylated RB, allowing them to completely bypass the 660 unlicensed $\mathrm{G}_{1}$ state.

\section{Discussion}

The cell-cycle of intestinal stem and transit-amplifying cells is poorly understood. By comparing the total and DNA-bound $\mathrm{Mcm} 2$ in intact intestinal crypts we provide new insights into how licensing and cell-cycle commitment are coupled in this tissue. We provide 


\section{Delayed activation of the DNA replication licensing system in $\operatorname{Lgr5(+)}$ intestinal stem cells}

666

667

668

669

670

671

672

673

674

675

676

677

678

679

680

681

682

683

684

685

686

687

688

evidence that after their final mitosis, transit amplifying cells do not license their replication

origins and immediately exit the cell cycle. We show that many Lgr5(+) stem cells spend the majority of $G_{1}$ in an unlicensed state, continually expressing $\mathrm{Mcm} 2$ and Ki67. In unlicensed$\mathrm{G}_{1}$, stem cells could be poised to respond to cues and progress past this restriction point to resume the cell division cycle.

$\operatorname{Lgr5}(+)$ stem cells have a cell-cycle length greater than transit-amplifying cells (Schepers et al., 2011). The biological relevance of this is currently unknown. The data presented here suggest a delay in origin licensing is a key feature of the prolonged cell-cycle of $\operatorname{Lgr} 5(+)$ cells. Although $\sim 80 \%$ of $\operatorname{Lgr} 5(+)$ cells are thought to be continually proliferative and express high levels of both Ki67 (Basak et al., 2014) and Mcm2, we found that most Lgr5(+) cells reside in an unlicensed state, with 2N DNA content and Mcm2 not bound to DNA. Since the licensed state defines proliferative fate commitment (Blow and Hodgson, 2002), we suggest that these cells are temporarily paused in $\mathrm{G}_{1}$, continuing to express proliferative makers such as Ki67 and Mcm2, but without fully committing to the cell cycle (Figure 8). We show that the number of $\operatorname{Lgr5}(+)$ cells with DNA bound-Mcm2 was similar to the number of proposed 'active' stem cells determined in lineage tracing experiments (Baker et al., 2014, Kozar et al., 2013).

Prolonged arrest may eventually result in degradation of $\mathrm{MCM} 2-7$ proteins and lead to induction of a state of deep quiescence $\left(G_{0}\right)$. Consistent with this idea, we observed that LRCs, thought to provide a reserve of quiescent stem cells, did not express Mcm2. The lack of $\mathrm{Mcm} 2$ expression may reflect that a significant period of time has passed since these cells divided. The delay in activating the licensing system may create a prolonged time-window for $\operatorname{Lgr} 5(+)$ cells to receive and interpret environmental cues before deciding to commit to 


\section{Delayed activation of the DNA replication licensing system in $\operatorname{Lgr5(+)}$ intestinal stem cells}

689 duplication, offering a means to control their number. It is likely that the majority of $\operatorname{Lgr5}(+)$

690 cells regularly resume their cell cycle, given their continual expression of proliferation

691 markers (Basak et al., 2014). The identity and decisions of Lgr5(+) cells are governed by stochastic choices and the ability to pause briefly in $\mathrm{G}_{1}$ offers them unique flexibility in making these choices.

As expected, the transition from unlicensed $G_{1}$ to licensed $G_{1}$ seems dependent on EGFR signalling. However, other pathways responsible for stem-cell maintenance can also significantly cause the appearance of a unique population of unlicensed cells with distinct cell-cycle dynamics. Growing evidence suggests that intestinal stem cell fate is not governed by asymmetric segregation of fate determinants (Lopez-Garcia et al., 2010, Snippert et al., 2010, Steinhauser et al., 2012). Instead, factors operating in the stem cell niche, such as Wnt and Notch signalling affect stem cell fate decisions and also reduce the cycle rate of intestinal stem cells (Hirata et al., 2013). This is consistent with the idea that cell fate choices are affected by decreasing proliferation rate and increased $\mathrm{G}_{0} / \mathrm{G}_{1}$ length. Indeed, extending $\mathrm{G}_{1}$ in mouse and human embryonic stem cells can drive differentiation (Calder et al., 2013, Coronado et al., 2013). Similarly, long $G_{1}$ phases are associated with the generation of fate-restricted progenitors during neurogenesis (Arai et al., 2011). An extended time window in the cell-cycle has been suggested to allow niche factors and/or fate determinants to accumulate to direct progenitor fate (Calegari and Huttner, 2003). In the case of adult intestinal stem cells, holding cells in $G_{1}$ may allow an extended time for cells licence rapidly and the cell cycle slows throughout differentiation (Matson et al., 2017). 


\section{Delayed activation of the DNA replication licensing system in $\operatorname{Lgr5}(+)$ intestinal stem cells}

711 However, like embryonic stem cells (Ge et al., 2015), intestinal stem cells appear to have

712 licensed more origins than non-stem cells when they enter $\mathrm{S}$ phase. This may help ensure

713 accurate and complete genome duplication in long-lived stem cells (Moreno et al., 2016).

714 With a higher demand for licensed origins, intestinal stem cells may therefore more readily

715 engage the licensing checkpoint that ensures that all origins are licensed before cells enter $\mathrm{S}$

716 phase (Alver et al., 2014, Liu et al., 2009, Shreeram et al., 2002). This additional demand for

717 licensed origins in stem cells may also explain why crypts hypomorphic for Mcm2 have a

718 stem-cell deficiency (Pruitt et al., 2007).

719 It is unclear how intestinal stem cells enter a significant unlicensed $G_{1}$ state. The simplest explanation is that licensing factors such as Cdt1 or Cdc6 are not readily available in newborn stem cells, and their synthesis has to be stimulated by an upstream signal for fate commitment via activation of E2F-driven transcription. This is the situation after prolonged quiescence, which is accompanied by passive downregulation of licensing factors (Coller, 2007). In contrast, in continually dividing cells their levels are maintained. Consistent with this idea, licensing factors such as Cdc6, along with many cyclin-CDK complexes, are down regulated beyond the end of the TA zone (Frey et al., 2000) (Smartt et al., 2007). Cells without a functional restriction point, such as $A p c$ mutant cells or most cancer cell lines, could immediately license their origins upon entering $G_{1}$ and can progress into S-phase without sufficient origins being licensed. Interestingly, both transit-amplifying cells and highly proliferative $A p c$ mutant cells are highly sensitive to replication inhibitors, such as

731 Gefitinib (S5 Figure H). Wild-type stem cells survive this treatment, potentially by engaging

732 the licensing checkpoint to reversibly stall in Unlicensed $G_{1}$. This suggests that the 
bioRxiv preprint doi: https://doi.org/10.1101/177477; this version posted February 14, 2018. The copyright holder for this preprint (which was not certified by peer review) is the author/funder. All rights reserved. No reuse allowed without permission.

\section{Delayed activation of the DNA replication licensing system in $\operatorname{Lgr5(+)}$ intestinal stem cells}

734 selective means to kill highly proliferative cells, such as Apc mutant cells (Shreeram et al., 2002, Blow and Gillespie, 2008).

In summary, we demonstrate that the dynamics of the DNA replication licensing system provides a new way for measuring the proliferative fate of intestinal stem cells. We suggest a model for 'working' intestinal stem cells that spend a significant proportion of $G_{1}$ in a unlicensed state until a proliferative fate decision is made. Correspondingly, exit from the cell-cycle in label retaining ' +4 ' cells leads to loss of proliferative capacity and loss of Mcm2 expression causing cells to enter a deeply $G_{0}$ quiescent state (Figure 6). The unlicensed $G_{1}$ that the unlicensed $\mathrm{G}_{1}$ state serves stem cells in controlling their numbers by regulating the cell-cycle.

\section{Author contributions}

746 T.D.C, J.J.B and I.N conceived and designed the study; T.D.C and I.P.N collected the data; Y.C assisted with organoid experiments; T.D.C performed the data analysis. J.J.B performed the modelling simulations. T.D.C, I.N and J.J.B wrote the manuscript.

\section{Conflicts of Interest}

750

The authors report no conflicts of interest.

\section{Acknowledgements}

752 We would like to thank members of the Näthke and Blow laboratories for general assistance

753 and helpful discussions; Dr Paul Appleton, Dr Graeme Ball and the Dundee Imaging and

754 Tissue Imaging Facility for support with microscopy and image analysis. The imaging facility 
bioRxiv preprint doi: https://doi.org/10.1101/177477; this version posted February 14, 2018. The copyright holder for this preprint (which was not certified by peer review) is the author/funder. All rights reserved. No reuse allowed without permission.

\section{Delayed activation of the DNA replication licensing system in Lgr5(+) intestinal stem cells}

755

756

757

758

759

760

761

762

763

764

765

766

767

768

769

770

771

772

773

774

775

776

777

778

779

780

781

782

783

784

785

786

787

is funded by the Welcome Trust Technology Platform award (097945/B/11/Z) and Welcome

Trust award (101468/Z/13/Z). We thank Dr Rosemary Clarke and the Dundee Flow

Cytometry Facility for support with flow cytometry, cell sorting and analysis. We also thank

Dr Richard Mort (University of Edinburgh) for Fucci2aR mouse tissue. This work was

supported by a programme grant from Cancer Research UK to I.N (C430/A11243) and to

J.J.B (C303/A14301), Wellcome Trust grant WT096598MA and an MRC studentship award to

T.D.C.

\section{REFERENCES}

ALVER, R. C., CHADHA, G. S. \& BLOW, J. J. 2014. The contribution of dormant origins to genome stability: from cell biology to human genetics. DNA repair, 19, 182-9.

ARAI, Y., PULVERS, J. N., HAFFNER, C., SCHILLING, B., NUSSLEIN, I., CALEGARI, F. \& HUTTNER, W. B. 2011. Neural stem and progenitor cells shorten S-phase on commitment to neuron production. Nature communications, 2, 154.

BAKER, A. M., CERESER, B., MELTON, S., FLETCHER, A. G., RODRIGUEZ-JUSTO, M., TADROUS, P. J., HUMPHRIES, A., ELIA, G., MCDONALD, S. A., WRIGHT, N. A., SIMONS, B. D., JANSEN, M. \& GRAHAM, T. A. 2014. Quantification of crypt and stem cell evolution in the normal and neoplastic human colon. Cell reports, 8, 940-7.

BARKER, N., VAN ES, J. H., KUIPERS, J., KUJALA, P., VAN DEN BORN, M., COZIJNSEN, M., HAEgebarth, A., KORVING, J., Begthel, H., PETERS, P. J. \& CLEVERS, H. 2007. Identification of stem cells in small intestine and colon by marker gene Lgr5. Nature, 449, $1003-7$.

BASAK, O., BEUMER, J., WIEBRANDS, K., SENO, H., VAN OUDENAARDEN, A. \& CLEVERS, H. 2017. Induced Quiescence of Lgr5+ Stem Cells in Intestinal Organoids Enables Differentiation of Hormone-Producing Enteroendocrine Cells. Cell stem cell, 20, 177190 e4.

BASAK, O., VAN DE BORN, M., KORVING, J., BEUMER, J., VAN DER ELST, S., VAN ES, J. H. \& CLEVERS, H. 2014. Mapping early fate determination in Lgr5+ crypt stem cells using a novel Ki67-RFP allele. The EMBO journal, 33, 2057-68.

BLOW, J. J. \& GILLESPIE, P. J. 2008. Replication licensing and cancer--a fatal entanglement? Nature reviews. Cancer, 8, 799-806.

BLOW, J. J. \& HODGSON, B. 2002. Replication licensing--defining the proliferative state? Trends in cell biology, 12, 72-8. 


\section{Delayed activation of the DNA replication licensing system in $\operatorname{Lgr5(+)}$ intestinal stem cells}

BUCZACKI, S. J., ZECCHINI, H. I., NICHOLSON, A. M., RUSSELL, R., VERMEULEN, L., KEMP, R. \& WINTON, D. J. 2013. Intestinal label-retaining cells are secretory precursors expressing Lgr5. Nature, 495, 65-9.

CALDER, A., ROTH-ALBIN, I., BHATIA, S., PILQUiL, C., LEE, J. H., BHATIA, M., LEVAdOUXMARTIN, M., MCNICOL, J., RUSSELL, J., COLLINS, T. \& DRAPER, J. S. 2013. Lengthened G1 phase indicates differentiation status in human embryonic stem cells. Stem cells and development, 22, 279-95.

CALEGARI, F. \& HUTTNER, W. B. 2003. An inhibition of cyclin-dependent kinases that lengthens, but does not arrest, neuroepithelial cell cycle induces premature neurogenesis. Journal of cell science, 116, 4947-55.

CHAMPERIS TSANIRAS, S., KANELLAKIS, N., SYMEONIDOU, I. E., NIKOLOPOULOU, P., LYGEROU, Z. \& TARAVIRAS, S. 2014. Licensing of DNA replication, cancer, pluripotency and differentiation: an interlinked world? Seminars in cell \& developmental biology, 30, 174-80.

CHWALINSKI, S. \& POTTEN, C. S. 1987. Influence of irradiation or thymidine (TdR) on the pattern of $3 \mathrm{H}-\mathrm{TdR}$ incorporation at each cell position in the crypts of the small intestine of the mouse. International journal of radiation biology and related studies in physics, chemistry, and medicine, 51, 243-54.

COLLER, H. A. 2007. What's taking so long? S-phase entry from quiescence versus proliferation. Nature reviews. Molecular cell biology, 8, 667-70.

CORONADO, D., GODET, M., BOURILLOT, P. Y., TAPPONNIER, Y., BERNAT, A., PETIT, M., AFANASSIEFF, M., MARKOSSIAN, S., MALASHICHEVA, A., IACONE, R., ANASTASSIADIS, K. \& SAVATIER, P. 2013. A short G1 phase is an intrinsic determinant of naive embryonic stem cell pluripotency. Stem cell research, 10, 118-31.

DALTON, S. 2015. Linking the Cell Cycle to Cell Fate Decisions. Trends in cell biology, 25, 592600.

DIMITROVA, D. S., PROKHOROVA, T. A., BLOW, J. J., TODOROV, I. T. \& GILBERT, D. M. 2002. Mammalian nuclei become licensed for DNA replication during late telophase. Journal of cell science, 115, 51-9.

EVRIN, C., CLARKE, P., ZECH, J., LURZ, R., SUN, J., UHLE, S., LI, H., STILLMAN, B. \& SPECK, C. 2009. A double-hexameric MCM2-7 complex is loaded onto origin DNA during licensing of eukaryotic DNA replication. Proceedings of the National Academy of Sciences of the United States of America, 106, 20240-5.

EWARD, K. L., OBERMANN, E. C., SHREERAM, S., LODDO, M., FANSHAWE, T., WILLIAMS, C., JUNG, H. I., PREVOST, A. T., BLOW, J. J., STOEBER, K. \& WILLIAMS, G. H. 2004. DNA replication licensing in somatic and germ cells. Journal of cell science, 117, 5875-86.

FATEHULLAH, A., APPLETON, P. L. \& NATHKE, I. S. 2013. Cell and tissue polarity in the intestinal tract during tumourigenesis: cells still know the right way up, but tissue organization is lost. Philosophical transactions of the Royal Society of London. Series B, Biological sciences, 368, 20130014.

FENG, D., TU, Z., WU, W. \& LIANG, C. 2003. Inhibiting the expression of DNA replicationinitiation proteins induces apoptosis in human cancer cells. Cancer research, 63, 7356-64.

FREY, M. R., CLARK, J. A., LEONTIEVA, O., URONIS, J. M., BLACK, A. R. \& BLACK, J. D. 2000. Protein kinase $C$ signaling mediates a program of cell cycle withdrawal in the intestinal epithelium. The Journal of cell biology, 151, 763-78. 


\section{Delayed activation of the DNA replication licensing system in $\operatorname{Lgr5}(+)$ intestinal stem cells}

FRIEDRICH, T. D., BEDNER, E., DARZYNKIEWICZ, Z. \& LEHMAN, J. M. 2005. Distinct patterns of $\mathrm{MCM}$ protein binding in nuclei of $S$ phase and rereplicating SV40-infected monkey kidney cells. Cytometry. Part A : the journal of the International Society for Analytical Cytology, 68, 10-8.

GAMBUS, A., KHOUDOLI, G. A., JONES, R. C. \& BLOW, J. J. 2011. MCM2-7 form double hexamers at licensed origins in Xenopus egg extract. The Journal of biological chemistry, 286, 11855-64.

GE, X. Q., HAN, J., CHENG, E. C., YAMAGUCHI, S., SHIMA, N., THOMAS, J. L. \& LIN, H. 2015. Embryonic Stem Cells License a High Level of Dormant Origins to Protect the Genome against Replication Stress. Stem cell reports, 5, 185-94.

GONZALEZ, M. A., TACHIBANA, K. E., LASKEY, R. A. \& COLEMAN, N. 2005. Control of DNA replication and its potential clinical exploitation. Nature reviews. Cancer, 5, 135-41.

HALAND, T. W., BOYE, E., STOKKE, T., GRALLERT, B. \& SYLJUASEN, R. G. 2015. Simultaneous measurement of passage through the restriction point and MCM loading in single cells. Nucleic acids research, 43, e150.

HIRATA, A., UTIKAL, J., YAMASHITA, S., AOKI, H., WATANABE, A., YAMAMOTO, T., OKANO, H., BARDEESY, N., KUNISADA, T., USHIJIMA, T., HARA, A., JAENISCH, R., HOCHEDLINGER, K. \& YAMADA, Y. 2013. Dose-dependent roles for canonical Wnt signalling in de novo crypt formation and cell cycle properties of the colonic epithelium. Development, 140, 66-75.

ILVES, I., PETOJEVIC, T., PESAVENTO, J. J. \& BOTCHAN, M. R. 2010. Activation of the MCM2-7 helicase by association with Cdc45 and GINS proteins. Molecular cell, 37, 247-58.

JURIKOVA, M., DANIHEL, L., POLAK, S. \& VARGA, I. 2016. Ki67, PCNA, and MCM proteins: Markers of proliferation in the diagnosis of breast cancer. Acta histochemica, 118, 544-52.

KINGSBURY, S. R., LODDO, M., FANSHAWE, T., OBERMANN, E. C., PREVOST, A. T., STOEBER, K. \& WILLIAMS, G. H. 2005. Repression of DNA replication licensing in quiescence is independent of geminin and may define the cell cycle state of progenitor cells. Experimental cell research, 309, 56-67.

KOZAR, S., MORRISSEY, E., NICHOLSON, A. M., VAN DER HEIJDEN, M., ZECCHINI, H. I., KEMP, R., TAVARE, S., VERMEULEN, L. \& WINTON, D. J. 2013. Continuous clonal labeling reveals small numbers of functional stem cells in intestinal crypts and adenomas. Cell stem cell, 13, 626-33.

KRUDE, T., MUSAHL, C., LASKEY, R. A. \& KNIPPERS, R. 1996. Human replication proteins hCdc21, hCdc46 and P1Mcm3 bind chromatin uniformly before S-phase and are displaced locally during DNA replication. Journal of cell science, 109 ( Pt 2), 309-18.

LEONE, G., DEGREGORI, J., YAN, Z., JAKOI, L., ISHIDA, S., WILLIAMS, R. S. \& NEVINS, J. R. 1998. E2F3 activity is regulated during the cell cycle and is required for the induction of S phase. Genes \& development, 12, 2120-30.

LIU, P., SLATER, D. M., LENBURG, M., NEVIS, K., COOK, J. G. \& VAZIRI, C. 2009. Replication licensing promotes cyclin D1 expression and $\mathrm{G} 1$ progression in untransformed human cells. Cell cycle, 8, 125-36.

LOPEZ-GARCIA, C., KLEIN, A. M., SIMONS, B. D. \& WINTON, D. J. 2010. Intestinal stem cell replacement follows a pattern of neutral drift. Science, 330, 822-5.

LYNCH, T. J., BELL, D. W., SORDELLA, R., GURUBHAGAVATULA, S., OKIMOTO, R. A., BRANNIGAN, B. W., HARRIS, P. L., HASERLAT, S. M., SUPKO, J. G., HALUSKA, F. G., 


\section{Delayed activation of the DNA replication licensing system in $\operatorname{Lgr5(+)}$ intestinal stem cells}

LOUIS, D. N., CHRISTIANI, D. C., SETTLEMAN, J. \& HABER, D. A. 2004. Activating mutations in the epidermal growth factor receptor underlying responsiveness of non-small-cell lung cancer to gefitinib. The New England journal of medicine, 350, 2129-39.

MACHIDA, Y. J., TEER, J. K. \& DUTTA, A. 2005. Acute reduction of an origin recognition complex (ORC) subunit in human cells reveals a requirement of ORC for Cdk2 activation. The Journal of biological chemistry, 280, 27624-30.

MAKAROVA, K. S., KOONIN, E. V. \& KELMAN, Z. 2012. The CMG (CDC45/RecJ, MCM, GINS) complex is a conserved component of the DNA replication system in all archaea and eukaryotes. Biology direct, 7, 7.

MATSON, J. P., DUMITRU, R., CORYELL, P., BAXLEY, R. M., CHEN, W., TWAROSKI, K., WEBBER, B. R., TOLAR, J., BIELINSKY, A. K., PURVIS, J. E. \& COOK, J. G. 2017. Rapid DNA replication origin licensing protects stem cell pluripotency. eLife, 6.

MORENO, A., CARRINGTON, J. T., ALBERGANTE, L., AL MAMUN, M., HAAGENSEN, E. J., KOMSELI, E. S., GORGOULIS, V. G., NEWMAN, T. J. \& BLOW, J. J. 2016. Unreplicated DNA remaining from unperturbed $S$ phases passes through mitosis for resolution in daughter cells. Proceedings of the National Academy of Sciences of the United States of America, 113, E5757-64.

MORT, R. L., FORD, M. J., SAKAUE-SAWANO, A., LINDSTROM, N. O., CASADIO, A., DOUGLAS, A. T., KEIGHREN, M. A., HOHENSTEIN, P., MIYAWAKI, A. \& JACKSON, I. J. 2014. Fucci2a: a bicistronic cell cycle reporter that allows Cre mediated tissue specific expression in mice. Cell cycle, 13, 2681-96.

MOYER, S. E., LEWIS, P. W. \& BOTCHAN, M. R. 2006. Isolation of the Cdc45/Mcm2-7/GINS (CMG) complex, a candidate for the eukaryotic DNA replication fork helicase. Proceedings of the National Academy of Sciences of the United States of America, 103, 10236-41.

MUNOZ, J., STANGE, D. E., SCHEPERS, A. G., VAN DE WETERING, M., KOO, B. K., ITZKOVITZ, S., VOLCKMANN, R., KUNG, K. S., KOSTER, J., RADULESCU, S., MYANT, K., VERSTEEG, R., SANSOM, O. J., VAN ES, J. H., BARKER, N., VAN OUDENAARDEN, A., MOHAMMED, S., HECK, A. J. \& CLEVERS, H. 2012. The Lgr5 intestinal stem cell signature: robust expression of proposed quiescent ' +4 ' cell markers. The EMBO journal, 31, 3079-91.

MUSAHL, C., HOLTHOFF, H. P., LESCH, R. \& KNIPPERS, R. 1998. Stability of the replicative $\mathrm{Mcm} 3$ protein in proliferating and differentiating human cells. Experimental cell research, 241, 260-4.

NAMDAR, M. \& KEARSEY, S. E. 2006. Analysis of Mcm2-7 chromatin binding during anaphase and in the transition to quiescence in fission yeast. Experimental cell research, 312, 3360-9.

NEVIS, K. R., CORDEIRO-STONE, M. \& COOK, J. G. 2009. Origin licensing and p53 status regulate Cdk2 activity during $\mathrm{G}(1)$. Cell cycle, 8, 1952-63.

OHTANI, K., IWANAGA, R., NAKAMURA, M., IKEDA, M., YABUTA, N., TSURUGA, H. \& NOJIMA, H. 1999. Cell growth-regulated expression of mammalian MCM5 and MCM6 genes mediated by the transcription factor E2F. Oncogene, 18, 2299-309.

POTTEN, C. S. \& LOEFFLER, M. 1990. Stem cells: attributes, cycles, spirals, pitfalls and uncertainties. Lessons for and from the crypt. Development, 110, 1001-20.

POTTEN, C. S., OWEN, G. \& BOOTH, D. 2002. Intestinal stem cells protect their genome by selective segregation of template DNA strands. Journal of cell science, 115, 2381-8. 


\section{Delayed activation of the DNA replication licensing system in $\operatorname{Lgr5(+)}$ intestinal stem cells}

PRUITT, S. C., BAILEY, K. J. \& FREELAND, A. 2007. Reduced Mcm2 expression results in severe stem/progenitor cell deficiency and cancer. Stem cells, 25, 3121-32.

PRUITT, S. C., FREELAND, A. \& KUDLA, A. 2010. Cell cycle heterogeneity in the small intestinal crypt and maintenance of genome integrity. Stem cells, 28, 1250-9.

REMUS, D., BEURON, F., TOLUN, G., GRIFFITH, J. D., MORRIS, E. P. \& DIFFLEY, J. F. 2009. Concerted loading of $\mathrm{Mcm}$ 2-7 double hexamers around DNA during DNA replication origin licensing. Cell, 139, 719-30.

RHIND, N. \& GILBERT, D. M. 2013. DNA replication timing. Cold Spring Harbor perspectives in biology, 5, a010132.

ROTH, S., FRANKEN, P., SACCHETTI, A., KREMER, A., ANDERSON, K., SANSOM, O. \& FODDE, R. 2012. Paneth cells in intestinal homeostasis and tissue injury. Plos One, 7, e38965.

SATO, T., VAN ES, J. H., SNIPPERT, H. J., STANGE, D. E., VRIES, R. G., VAN DEN BORN, M., BARKER, N., SHROYER, N. F., VAN DE WETERING, M. \& CLEVERS, H. 2011. Paneth cells constitute the niche for Lgr5 stem cells in intestinal crypts. Nature, 469, 415-8.

SCHEPERS, A. G., VRIES, R., VAN DEN BORN, M., VAN DE WETERING, M. \& CLEVERS, H. 2011. Lgr5 intestinal stem cells have high telomerase activity and randomly segregate their chromosomes. The EMBO journal, 30, 1104-9.

SHREERAM, S., SPARKS, A., LANE, D. P. \& BLOW, J. J. 2002. Cell type-specific responses of human cells to inhibition of replication licensing. Oncogene, 21, 6624-32.

SMARTT, H. J., GUILMEAU, S., NASSER, S. V., NICHOLAS, C., BANCROFT, L., SIMPSON, S. A., YEH, N., YANG, W., MARIADASON, J. M., KOFF, A. \& AUGENLICHT, L. H. 2007. p27kip1 Regulates cdk2 activity in the proliferating zone of the mouse intestinal epithelium: potential role in neoplasia. Gastroenterology, 133, 232-43.

SNIPPERT, H. J., VAN DER FLIER, L. G., SATO, T., VAN ES, J. H., VAN DEN BORN, M., KROONVEENBOER, C., BARKER, N., KLEIN, A. M., VAN RHEENEN, J., SIMONS, B. D. \& CLEVERS, H. 2010. Intestinal crypt homeostasis results from neutral competition between symmetrically dividing Lgr5 stem cells. Cell, 143, 134-44.

STEINHAUSER, M. L., BAILEY, A. P., SENYO, S. E., GUILLERMIER, C., PERLSTEIN, T. S., GOULD, A. P., LEE, R. T. \& LECHENE, C. P. 2012. Multi-isotope imaging mass spectrometry quantifies stem cell division and metabolism. Nature, 481, 516-9.

STOEBER, K., TLSTY, T. D., HAPPERFIELD, L., THOMAS, G. A., ROMANOV, S., BOBROW, L., WILLIAMS, E. D. \& WILLIAMS, G. H. 2001. DNA replication licensing and human cell proliferation. Journal of cell science, 114, 2027-41.

SYMEONIDOU, I. E., KOTSANTIS, P., ROUKOS, V., RAPSOMANIKI, M. A., GRECCO, H. E., BASTIAENS, P., TARAVIRAS, S. \& LYGEROU, Z. 2013. Multi-step loading of human minichromosome maintenance proteins in live human cells. The Journal of biological chemistry, 288, 35852-67.

TEER, J. K., MACHIDA, Y. J., LABIT, H., NOVAC, O., HYRIEN, O., MARHEINEKE, K., ZANNISHADJOPOULOS, M. \& DUTTA, A. 2006. Proliferating human cells hypomorphic for origin recognition complex 2 and pre-replicative complex formation have a defect in p53 activation and Cdk2 kinase activation. The Journal of biological chemistry, 281, 6253-60.

TODOROV, I. T., WERNESS, B. A., WANG, H. Q., BUDDHARAJU, L. N., TODOROVA, P. D., SLOCUM, H. K., BROOKS, J. S. \& HUBERMAN, J. A. 1998. HsMCM2/BM28: a novel proliferation marker for human tumors and normal tissues. Laboratory investigation; a journal of technical methods and pathology, 78, 73-8. 


\section{Delayed activation of the DNA replication licensing system in Lgr5(+) intestinal stem cells}

TRANI, D., NELSON, S. A., MOON, B. H., SWEDLOW, J. J., WILLIAMS, E. M., STRAWN, S. J., APPLETON, P. L., KALLAKURY, B., NATHKE, I. \& FORNACE, A. J., JR. 2014. High-energy particle-induced tumorigenesis throughout the gastrointestinal tract. Radiation research, 181, 162-71.

VAN DER FLIER, L. G. \& CLEVERS, H. 2009. Stem cells, self-renewal, and differentiation in the intestinal epithelium. Annual review of physiology, 71, 241-60.

VAN ES, J. H., VAN GIJN, M. E., RICCIO, O., VAN DEN BORN, M., VOOIJS, M., BEGTHEL, H., COZIJNSEN, M., ROBINE, S., WINTON, D. J., RADTKE, F. \& CLEVERS, H. 2005. Notch/gamma-secretase inhibition turns proliferative cells in intestinal crypts and adenomas into goblet cells. Nature, 435, 959-63.

WILLIAMS, G. H., ROMANOWSKI, P., MORRIS, L., MADINE, M., MILLS, A. D., STOEBER, K., MARR, J., LASKEY, R. A. \& COLEMAN, N. 1998. Improved cervical smear assessment using antibodies against proteins that regulate DNA replication. Proceedings of the National Academy of Sciences of the United States of America, 95, 14932-7.

WILLIAMS, G. H., SWINN, R., PREVOST, A. T., DE CLIVE-LOWE, P., HALSALL, I., GOING, J. J., HALES, C. N., STOEBER, K. \& MIDDLETON, S. J. 2004. Diagnosis of oesophageal cancer by detection of minichromosome maintenance 5 protein in gastric aspirates. British journal of cancer, 91, 714-9.

YIN, X., FARIN, H. F., VAN ES, J. H., CLEVERS, H., LANGER, R. \& KARP, J. M. 2014. Nicheindependent high-purity cultures of Lgr5+ intestinal stem cells and their progeny. Nature methods, 11, 106-12. 
bioRxiv preprint doi: https://doi.org/10.1101/177477; this version posted February $14,2018$. The copyright holder for this preprint (which was not certified by peer review) is the author/funder. All rights reserved. No reuse allowed without permission.

\section{Delayed activation of the DNA replication licensing system in $\operatorname{Lgr5(+)}$ intestinal stem cells}

Figure Legends

996 Figure 1. Mcm2 is expressed ubiquitously along the crypt-villus axis and declines slowly as 997 cells differentiate

998 (A) Sections of normal human (top panel) and mouse (bottom panel) small-intestine were 999 stained with Phalloidin (Green) and an antibody against Mcm2 (Red). Scale bars: $200 \mu \mathrm{m}$.

1000 (B) Mean Mcm2 intensities for segmented nuclei were plotted along the crypt-villus axis for 1001 mouse and human tissue. Location of the crypt and villus domains is indicated.

1002

(C) An intestinal crypt stained with Hoechst (Blue), Phalloidin (Green) and an antibody against Mcm2 (Red). Individual cells in interphase and mitosis (metaphase and cytokinesis) are outlined by dashed white lines.

(D) Maximum intensity projections of whole-mount intestinal tissue revealing intestinal crypts and villi (left panels). Individual $X-Y$ sections are also shown to reveal the epithelium (right panels). Tissue was stained with Phalloidin (Green) and Hoechst (Blue) and an antibody against Mcm2 (Red). The alternating pattern of Mcm2(+) (Green stars) and Mcm2() (Orange stars) in the crypt base is highlighted)

1010 (E) Images of Lgr5-GFP stem cells (Green) (top panel) co-stained with a Mcm2 antibody (Red). The correlation (Pearson's correlation $\mathrm{R}=0.81, \mathrm{p}<0.0001$ ) between mean $\mathrm{Mcm} 2$ and Lgr5-GFP intensities for 69 Lgr5-GFP(+) cells normalised to the maximum intensity for an individual crypt is shown.

1014 (F) Images of UEA(+) Paneth Cells (top panels) co-stained with an Mcm2 antibody (Red) and 1015 UEA (Green). Mean Mcm2 intensity for segmented nuclei of UEA(+) Paneth cells was compared with interphase cells (Right panels).

1017 (G) Mcm2 (Green) and UEA (Red) expression in subsets of UEA(+) cells in crypt and villus 1018 domains. UEA $(+)$ cells at the crypt base represent Paneth cells.

1019 (H) Quantification of mean Mcm2 intensity in individual UEA(+) cell populations. UEA(+) cells in the crypt base (Paneth cells, $\mathrm{N}=224$ ), in the upper crypt compartment (Crypt, $\mathrm{N}=132$ ) and in the villus compartment (Villus, $\mathrm{N}=225$ ) were identified manually, and the nuclear $\mathrm{Mcm} 2$ intensity was determined for individual cells (All cells, $N=33,736$ ). There was a significant difference between UEA $(+)$ cells in the crypt and villus compartments ( $T$ test, $p<0.0001$ ) 
bioRxiv preprint doi: https://doi.org/10.1101/177477; this version posted February 14, 2018. The copyright holder for this preprint (which was not certified by peer review) is the author/funder. All rights reserved. No reuse allowed without permission.

\section{Delayed activation of the DNA replication licensing system in $\operatorname{Lgr5(+)}$ intestinal stem cells}

1025 Figure 2. Visualising $\mathrm{Mcm} 2$ licensing in intestinal crypts

1026 (A) Representative bright-field images of extracted and unextracted isolated intestinal 1027 crypts. Scale bar: $90 \mu \mathrm{m}$

1028 (B) Representative images of isolated crypts stained with antibodies against Mcm2 (Red) or 1029 Ki67 (Purple). Scale bar: $10 \mu \mathrm{m}$

1030 (C) The Mcm2 labelling index for unextracted and extracted crypts is significantly different 1031 (Mean +/- SEM, N=10 crypts ( $T$ test, $p<0.0001$ ).

1032 (D) Representative intestinal crypts stained with Hoechst (Blue) and antibodies against $1033 \mathrm{Mcm} 2$ (Red) and phospho-histone H3 (pH-H3) (Green).

1034 (E) Representative flow cytometry profiles for extracted and unextracted isolated crypt 1035 epithelial cells showing Mcm2 vs. DNA content.

(E') Suggested model of the licensing profile shown in panel E. Deeply quiescent cells, do not express $\mathrm{Mcm} 2$ and have a no detectable $\mathrm{Mcm} 2$ signal. Cells expressing soluble $\mathrm{Mcm} 2$ (Unlicensed $\mathrm{G}_{1}$ ) show a similar $\mathrm{Mcm} 2$ signal to $\mathrm{G}_{2}$ cells. After a proliferative fate decision has been made, origins become licensed and cells commit to S-phase entry. Cells enter S-phase after maximal origin licensing (Active- $\mathrm{G}_{1}$ ). During S-phase, $\mathrm{Mcms}$ are then displaced from DNA during replication.

1042 (F) Representative images of extracted and unextracted intestinal organoids stained with an 1043 antibody against Mcm2 (Red).

1044 (G) The Mcm2 labelling index for unextracted and extracted organoids. Data is displayed as 1045 Mean + - SEM, $N=3$ organoids and shows a significant difference ( $T$ test, $p<0.0001$ ). 


\section{Delayed activation of the DNA replication licensing system in $\operatorname{Lgr5}(+)$ intestinal stem cells}

\section{Figure 3. The licensing state defines distinct proliferative zones in intestinal crypts}

1047 (A) Representative image of an extracted intestinal crypt isolated after a 1 hour EdU pulse in vivo (EdU, Green) and stained with Hoechst (Blue) and antibodies against Mcm2 (Red) and $\mathrm{pH}-\mathrm{H} 3$ (White). Co-staining shows distinct cell-cycle phases (bottom panels): Licensed cells committed in $\mathrm{G}_{1}(\mathrm{Mcm} 2(+)$, $\mathrm{EdU}(-))$; Early $(\mathrm{Mcm} 2(+)$, $\mathrm{EdU}(+))$ to Late $(\mathrm{Mcm} 2(-)$, $\mathrm{EdU}(+)) \mathrm{S}-$ phase), and mitotic cells $(\mathrm{pH}-\mathrm{H} 3(+))$. Negative cells represent deeply quiescent $\left(\mathrm{G}_{0}\right)$, terminally differentiated cells or cells in $G_{1}$, which have not made a proliferative fate decision, remaining unlicensed. The crypt base is to the left of the displayed image.

(B) Nuclear volume was estimated in cells at the distinct cell-cycle phases identified previously: Negative $\left(G_{0} / G_{1} / G_{2}: N=115\right), G_{1}$ Licensed (Mcm(+), EdU(-): $\left.N=38\right)$, S-phase $(\mathrm{Mcm}(+), \operatorname{EdU}(+): \mathrm{N}=24)$ and Late-S/G$(\mathrm{Mcm}(-), \mathrm{EdU}(+): \mathrm{N}=26)$. Top Panels show representative examples of each cell-cycle phase and the associated 3D rendered nuclei. There was a significant difference in the size of Licensed $G_{1}, S$ and Late-S/G $G_{2}$ nuclei ( $T$ test, $\mathrm{p}<0.0001)$.

(C) Representative images of intestinal crypts isolated after a 1 hour EdU pulse (Green) in vivo. Displayed are 3D projections of extracted and unextracted crypts stained with Hoechst (Blue) and an antibody against Mcm2 (Red). The crypt base is to the left of the displayed image.

(D) Comparison between cells expressing $\mathrm{Mcm} 2$ protein and DNA-bound $\mathrm{Mcm} 2$ along the crypt-villus axis between unextracted ( $\mathrm{N}=101$ crypts) and extracted ( $\mathrm{N}=109$ crypts) (taken from 3 mice). Data is displayed as the mean \% of cells per set distance bin.

(E) All cells were divided into 4 distinct groups based on $\mathrm{Mcm} 2$ and EdU intensities. These groups represent distinctive cell-cycle phases as defined by their total (unextracted $\mathrm{N}=101$ crypts) or licensed (extracted $\mathrm{N}=109$ crypts) $\mathrm{Mcm} 2$ content: Extracted: 1) Unlicensed $(\mathrm{Mcm} 2(-), \operatorname{EdU}(-)), 2) \mathrm{G}_{1}$ licensed $\left.(\mathrm{Mcm} 2(+), \operatorname{EdU}(-)), 3\right)$ Early/Mid S-phase $(\mathrm{Mcm} 2(+)$, $\mathrm{EdU}(+))$ and 4) Late-S/G $\mathbf{2}(\mathrm{Mcm} 2(-)$, EdU(+)). The data is represented as the population mean of the total cells per distance bin, Mean $+/-$ SEM.

1073 (F) The distance of the most distal $\mathrm{Mcm} 2(+)$ and $\mathrm{EdU}(+)$ cells to the crypt base was compared in extracted and unextracted crypts. Data was scored manually for 10 representative crypts per condition. Licensed cells (Mcm2(+)) were significantly closer to the crypt base than $\mathrm{EdU}(+)$ cells ( $T$ test, $p=0.0015$. Cells expressing $\mathrm{Mcm} 2$ protein extended significantly above the last $\mathrm{EdU}(+)$ cell $(T$ test, $p<0.0003)$

1078 (G) Representative images of crypts isolated 17 hours after administration of EdU (Green). 3D projections of extracted and unextracted crypts stained with Hoechst (Blue) and an antibody against Mcm2 (Red) are shown.

(H) Cells were divided into 4 distinct groups as in Panel E ( $N=51$ Crypts). 


\section{Delayed activation of the DNA replication licensing system in $\operatorname{Lgr5(+)}$ intestinal stem cells}

Figure 4. Intestinal stem cells reside in a paused unlicensed $\mathbf{G}_{1}$

1084 (A) Quantification of cell cycle stages for cells in the stem cell (SC) compartment $(<40 \mu \mathrm{m}$ 1085 from the crypt base) and in the early transit-amplifying (TA) compartment (40-80 $\mu \mathrm{m}$ from 1086 the crypt base), as described in Figure $3 \mathrm{E}$ ( $\mathrm{N}=49$ crypts).

1087 (B) Representative image of an extracted crypt base isolated 1 hour after a pulse of EdU 1088 (Green) and stained with Hoechst (Blue), UEA (Red) and antibodies against Mcm2 (White). 1089 Nuclear morphology and UEA signal were used to distinguish between UEA(+) Paneth Cells 1090 (outlined by dashed lines and nuclei marked with blue stars) and UEA(-) stem cells (situated 1091 between outlined Paneth cells and with nuclei marked by red stars).

1092 (C) The average \% of UEA(-) stem cells that fall into the previously defined cell-cycle bins: 1093 (Unlicensed; $G_{1}$ licensed; S-phase; $S / G_{2}$ phase; $N=68$ crypts).

(D) Representative flow cytometry profiles of (i) isolated Lgr $^{\mathrm{Hi}}$ intestinal stem cells from 3 mice, showing DNA-bound $\mathrm{Mcm} 2$ and DNA content. The $2 \mathrm{~N}\left(\mathrm{G}_{1}\right)$ cells of the same population are also shown (ii). The respective gated populations for Unlicensed $\mathrm{G}_{1}$ (Black), Licensed (Red), S-phase (Yellow) and $\mathrm{G}_{2} / \mathrm{M}$ (Green) are shown. The Ki67 content of the Licensed and Unlicensed $\mathrm{G}_{1}$ cells are also shown (iii).

1099 (E) The frequency distribution of mean DNA-bound Mcm2 intensities for $\mathrm{Mcm}_{2}(+)$ cells in $\mathrm{G}_{1}$ 1100 cells.

1101 (F) Simulated ergodic rate analysis of origin licensing during $G_{1}$. We simulated origin licensing dynamics during $G_{1}$, varying the licensing rate and incorporating a significant paused period (Unlicensed $G_{1}$ ). The displayed histograms show the frequency distribution of DNA-bound $\mathrm{Mcm} 2$ of $\mathrm{G}_{1}$ cells. Please refer to materials and methods for further information. However, an analogy to explain the model is as follows: Origin licensing through $\mathrm{G}_{1}$ can be thought of in terms of cars travelling along a long stretch of motorway: if cars enter the motorway at a fixed rate (i.e. unsynchronised cell cycles, cells entering $\mathrm{G} 1$ ) the density of cars at any one point is inversely proportional to the speed they are travelling at ('speed' in our case means the rate of licensing). We have added the concept of delays at the start and end, like tollbooths. In our model, there is a minimum drive time (the minimum length of $G_{1}$ required for cells to grow to a critical size before they enter $\mathrm{S}$ phase (arbitrarily set at ' $100 \%$ '). If the speed of the cars means they don't reach the end of the motorway before this time is up, cars maintain a constant speed along the entire road, and exit the motorway as soon as they reach the end. If cars drive faster and they reach the end before this time is up ( $>100 \%)$, they have to wait at the end of the motorway till the critical time is expired, resulting in a peak accumulation at the fully licensed point. Unlicensed $\mathrm{G}_{1}$ is an enforced time that cars have to wait once they enter the motorway before they are allowed to drive along it. This creates a peak on the left (unlicensed cells). If the cars then drive slowly, when they get to the end of the motorway, they exit immediately because the critical time has expired (centre panels), but if they drive fast enough they reach the end of the motorway before the critical time has expired. This results in a peak accumulation at both minimally and maximally licensed points. 
bioRxiv preprint doi: https://doi.org/10.1101/177477; this version posted February 14,2018 . The copyright holder for this preprint (which was not certified by peer review) is the author/funder. All rights reserved. No reuse allowed without permission.

\section{Delayed activation of the DNA replication licensing system in Lgr5(+) intestinal stem cells}

1123 (G) Comparison of DNA-bound Mcm2 content of Lgr5(+) and Lgr5(-) $\mathrm{G}_{1}$ cells and of cells in 1124 very early S-phase.

\section{Figure 5. Label retaining cells are in a deep- $\mathrm{G}_{0}$ state}

1126 (A) Labelling strategy. H2B-GFP expression was induced in all intestinal epithelial cells in 1127 H2B-GFP mice by administration of doxycycline for 7 days. After complete labelling, 1128 doxycycline was removed and mice rested for 7 days. During this chase period, the majority 1129 of H2B-GFP(+) cells are lost by label dilution due to cell division and upward migration. Both 1130 Paneth cells and +4 Label retaining cells are H2B-GFP(+) after the chase period. +4 Label 1131 retaining cells were distinguished from Paneth cells on the lack of UEA staining (Buczacki et 1132 al., 2013).

1133 (B) Representative images of whole-mount sections of H2B-GFP expressing small-intestinal 1134 tissue after a 7-day labelling period (i). A vibratome section (ii) of intestinal tissue after a 1135 subsequent 7-day chase period, stained with Hoechst (nuclei), UEA (Grey), and an antibody 1136 against $\mathrm{Mcm} 2$ (Red). An enlarged image of the marked crypt is shown. A UEA(-) label 1137 retaining cell (LRC) is marked by the white arrow). Quantification of the mean GFP intensity 1138 for all cells along the crypt-villus axis after the 7 days chase period is shown (iii).

1139 (C) A representative image (i) of a label-retaining cell in an intestinal crypts stained with 1140 Hoechst (Blue), UEA (White) and an antibody against Mcm2 (Red). The label retaining cell 1141 (White arrow) does not express $\mathrm{Mcm} 2$. The quantification of $\mathrm{Mcm} 2$ expression in label 1142 retaining cells $(N=12)$, Paneth cells $(N=116)$ and all cells $(N=543)$ is shown (iii).

1143 (D) Representative images of extracted H2B-GFP crypts after the 7-Day chase period. H2B1144 GFP ${ }^{\mathrm{Hi}}$ cells (bright Green) represent Paneth cells and +4 cells (i), and H2B-GFP ${ }^{\text {Low }}$ cells (Faint 1145 Green) represent daughter cells (white arrow) that have diluted H2B-GFP content as a result 1146 of cell division (ii). The quantification of DNA-bound $\mathrm{Mcm} 2$ in GFP ${ }^{\mathrm{Hi}}$ label retaining (LR) and 1147 GFP ${ }^{\text {low }}$ daughter cells compared with the total cell population (all cells) is shown (iii). 
bioRxiv preprint doi: https://doi.org/10.1101/177477; this version posted February 14, 2018. The copyright holder for this preprint (which was not certified by peer review) is the author/funder. All rights reserved. No reuse allowed without permission.

\section{Delayed activation of the DNA replication licensing system in $\operatorname{Lgr5(+)}$ intestinal stem cells}

\section{Figure 6. Licensing dynamics in intestinal organoids}

1149 (A) Representative image of an unextracted and extracted intestinal organoid stained with 1150 Hoechst (Blue), and an antibody against Mcm2 (Red) after a 1 hour EdU pulse (green).

1151 (B) Representative flow cytometry profiles from isolated organoids cells showing Ki67 (i) or 1152 DNA-bound Mcm2 (ii) content vs DNA content.

1153 (C) Representative flow cytometry profile from cells isolated from cultured organoids (i) or 1154 intestinal crypts (ii) showing DNA-bound Mcm2 vs Ki67 (See also S5 Figure A). Ki67 loss and 1155 subsequent loss of $\mathrm{Mcm} 2$ during differentiation is apparent, starting from Unlicensed $\mathrm{G}_{1}$ 1156 (dashed arrow). Quantification of discrete populations (gates shown in i) was performed: 1) $1157 G_{0}, 2$ ) Transition $\left(G_{0} \leftrightarrow\right.$ Unlicensed $\left.G_{1}\right), 3$ ) Unlicensed $G_{1}, 4$ ) Licensed $\left.G_{1}, 5\right)$ S-Phase, 6) Late$1158 \mathrm{~S} / \mathrm{G}_{2} / \mathrm{M}$. (N=3).

1159 (D) Representative flow cytometry profiles of isolated organoid epithelial cells grown in ENR 1160 (control) and treated with the EGFR inhibitor Gefitinib, for the indicated times (i-iii). After 4 1161 Days in Gefitinib, organoids were reactivated by removal of the Gefitinib and re-addition of 1162 fresh growth factors (ENR) for 2 days (iv). Displayed are profiles comparing DNA-bound 1163 Mcm2 vs Ki67 (Top panels) or total Mcm2 content (Bottom panels).

1164 (E) The $G_{1}$ cell populations as shown in (D) were quantified. DNA-bound Mcm2 profiles (i) 1165 show 1) Unlicensed $G_{1}, 2$ ) Licensed $\left.G_{1}, 3\right)$ Transition $\left(G_{0} \leftrightarrow\right.$ Unlicensed $\left.\left.G_{1}\right), 4\right) G_{0}$ populations. 1166 Total-Mcm2 profiles (ii) show $\mathrm{Mcm} 2$ expressing $(\mathrm{Mcm} 2(+))$ and non-expressing (Mcm2(-)) 1167 Cells. ( $\mathrm{N}=3$ organoids) 


\section{Delayed activation of the DNA replication licensing system in $\operatorname{Lgr5(+)}$ intestinal stem cells}

Figure 7. Unlicensed $\mathrm{G}_{1}$ is lost in Apc mutant epithelium

1170 (A) A representative vibratome section of $\mathrm{Apc}^{\mathrm{Min} /+}$ intestinal epithelium stained with 1171 Hoechst (nuclei), Phalloidin and an antibody against Mcm2. Regions of normal histology and 1172 a region containing a polyp are highlighted.

1173 (B) Representative image of an extracted $\mathrm{Apc}^{\mathrm{Min} /+}$ isolated crypt (i) stained with Hoechst 1174 (Nuclei) and an antibody against Mcm2 (Red), after a 1 hour EdU pulse (Green). A 1175 representative image of an abnormally elongated crypt is displayed (ii) showing a clonal 1176 ribbon of cells in the distal transit-amplifying compartment which are EdU(+). Quantification 1177 of cell-cycle stages across the crypt axis (Figure 3) is shown (iii).

1178 (C) Representative bright field images of organoids cultured from wild-type and organoids 1179 from $\mathrm{Apc}^{\mathrm{Min} /+}$ mice that have undergone loss of heterozygosity ( $\mathrm{Apc}^{\mathrm{Min} / \mathrm{Min}}$ ).

1180 (D) Representative images of unextracted and extracted $A p c^{\mathrm{Min} / \mathrm{Min}}$ organoids stained with 1181 Hoechst (nuclei), an antibody against Mcm2 (red), after a 1 hour EdU pulse.

1182 (E) Representative flow cytometry profiles from cells from extracted wild-type and Apc ${ }^{\mathrm{Min} / \mathrm{Min}}$ 1183 organoids showing DNA-bound $\mathrm{Mcm} 2$ vs DNA content (i). The $2 \mathrm{~N} \mathrm{G}_{1}$ cells of the shown 1184 profile are displayed (ii) showing Unlicensed $G_{1}$, Early $G_{1}$ and Peak (fully licensed) $G_{1}$ 1185 populations.

1186 (F) Quantification of the populations described in Panel Eii. Data is displayed as mean +/1187 SEM, $\mathrm{N}=3$ organoids.

1188 (G) Western blot of RB and pRB (low and high exposures) levels between wild-type and 1189 $\mathrm{Apc}^{\mathrm{Min} / \mathrm{Min}}$ organoids. Two bands corresponding to hypo- and hyper-phospohorylated RB can 1190 be observed.

(H) Quantification of the fold increase of $p R B: R B$ for $A p c^{M i n / M i n}$ organoids $(N=3)$ and polps isolated from $\mathrm{Apc}^{\mathrm{Min} /+}$ mice $(\mathrm{N}=6)$, compared to wild-type organoids and tissue. 
bioRxiv preprint doi: https://doi.org/10.1101/177477; this version posted February 14,2018 . The copyright holder for this preprint (which was not certified by peer review) is the author/funder. All rights reserved. No reuse allowed without permission.

\section{Delayed activation of the DNA replication licensing system in $\operatorname{Lgr5(+)}$ intestinal stem cells}

\section{Figure 8. Model of Origin licensing dynamics in intestinal epithelial cells}

1195 In a normal cell-cycle, Mcms are expressed ubiquitously in all stages. The licensing of DNA with MCM2-7 occurs in late $M$ and throughout $G_{1}$, when a cell receives a stimulus to commit to the cell cycle. As DNA is replicated during S-phase, MCM2-7s are displaced from DNA and are prevented from relicensing in $\mathrm{G}_{2}$. During terminal differentiation, MCM2-7 are not actively transcribed and the proteins are gradually lost in post-mitotic cells. However, after the final mitotic division, cells make a binary decision never to license their DNA, even though the protein is still present. Mcm proteins then degrade slowly, where cells enter a terminally differentiated state (deep $\mathrm{G}_{0}$ ). Alternatively, cells can exit mitosis, not relicense their DNA but maintain proliferative markers and disengage from the cell cycle for some time (Unlicensed $\mathrm{G}_{1}$ ). Two major classes of intestinal stem cells exist: 'Active' stem cells, engaged with the cell-cycle, and reserve, quiescent Label Retaining Cells. Label retaining cells are in a state of 'deep' quiescence, and do not contain MCM2-7 because they have disengaged from the cell cycle for some time. In this study, we show that most 'Active' Lgr5(+) stem cells reside in an unlicensed state, but contain MCM2-7 proteins. These cells reside in an 'Unlicensed- $\mathrm{G}_{1}$ ' until they make a proliferative fate decision, enter the cell-cycle and license. This provides an explanation for the elongated cell-cycle of Intestinal stem cells: They reside in a partial resting state where they may be able to respond to niche cues to divide. This therefore may constitute a unique mechanism to control stem cell numbers. 
bioRxiv preprint doi: https://doi.org/10.1101/177477; this version posted February 14,2018 . The copyright holder for this preprint (which was not certified by peer review) is the author/funder. All rights reserved. No reuse allowed without permission.

\section{Delayed activation of the DNA replication licensing system in Lgr5(+) intestinal stem cells}

\section{Supplementary Figure Legends}

\section{S1 Figure. Image analysis}

1215 (A) Image analysis work-flow.

1216 (B) Representative image of an extracted isolated crypt 1 hour after an EdU pulse (Green) 1217 stained with Hoechst (Blue) and an antibody against Mcm2 (Red).

1218 (C) Detection of nuclei in the crypt in panel A in 3D. Nuclei were detected in 3D using 1219 segmentation tools in Imaris. Detection was validated visually or each individual crypt.

1220 (D) Segmentation of the region of interest defined by nuclei detection in panel B.

1221 (E) A distance transform was performed in Imaris to measure the distance of each nucleus 1222 to a reference nucleus at the crypt base. Visual representations of distances divided into

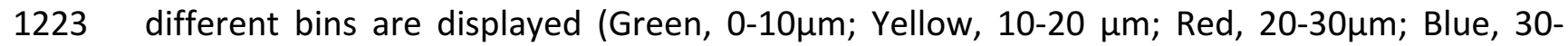

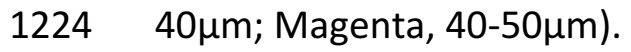

1225 (F) Representative 3D quantification of the crypt in panel A shows the distance from the crypt base (X-axis), DNA-bound Mcm2 (Y-axis) and EdU incorporation (Z-axis).

1227 (G) An overview of the gating strategy used for flow cytometry experiments. Intestinal 1228 epithelial cells were separated from debris on the basis of forward and side scatter. Single 1229 cells were subsequently distinguished from doublets based on pulse-width gating. Negative gates were set on control samples stained with secondary antibody alone. Unlicensed $G_{1}$ (Population 1) and licensed- $\mathrm{G}_{1}$ (Population 2) were distinguished based on DNA-content and based on the threshold set by the negative control samples. S-phase cells (Population 3) can be seen as an arc of cells emanating from the fully licensed cell population, increasing in DNA content whilst losing DNA-bound $\mathrm{Mcm} 2 . \mathrm{G}_{2} / \mathrm{M}$ cells (Population 4 ) can be seen as a population with 4N DNA content and lacking DNA-bound $\mathrm{Mcm} 2$. 
bioRxiv preprint doi: https://doi.org/10.1101/177477; this version posted February 14,2018 . The copyright holder for this preprint (which was not certified by peer review) is the author/funder. All rights reserved. No reuse allowed without permission.

\section{Delayed activation of the DNA replication licensing system in Lgr5(+) intestinal stem cells}

\section{S2 Figure. Clonal cell-cycle patterns in the intestinal epithelium}

1237 (A) Representative section through an extracted crypt after a 1 hour EdU pulse (Green) and 1238 stained with Hoechst (Blue) and an antibody against Mcm2 (Red). Discrimination of cell1239 cycle staging using DNA-bound $\mathrm{Mcm} 2$ and EdU incorporation patterns allows visualisation of 1240 clonal cell-cycle field effects revealing many neighbouring cells with similar DNA-bound $1241 \mathrm{Mcm} 2$ and DNA replication patterns. These clones may represent lineages of from single 1242 cells that progress through the cell cycle at the same rate.

1243 (B) Representative image of an isolated crypt in which surface rendering was performed on 1244 all nuclei and colour codes applied to reflect cell-cycle stage. Representative cell-cycle 1245 distributions for isolated Ki67(+), Lgr5(+) and Lgr5(-) intestinal epithelial cells are shown.

1246 (C) Representative cell-cycle distributions for isolated Ki67(+), Lgr5(+) and Lgr5(-) intestinal 1247 epithelial cells. The average of each cell-cycle phase is displayed for duplicate isolations.

1248 (D) Nuclear volumes were rendered for individual nuclei in whole intestinal crypts isolated 1 hour after labelling with EdU. Image shows nuclei (Blue), EdU (Green) and licensed Mcm2 (Red). Maximum intensity projections of the original image are displayed at the top and corresponding rendered nuclei at the bottom. Nuclear surfaces were colour-coded according to cell-cycle states: Blue, unlicensed; Red, Licensed $\mathrm{G}_{1}$; Yellow, S-phase; Green, Late-S/G . Nuclear volumes were measured for all nuclei in representative crypts $(\mathrm{N}=3)$. Unlicensed ( $N=368) ; \mathrm{G}_{1}(\mathrm{~N}=104) ; \mathrm{S}$-phase $(\mathrm{N}=41)$; Late- $\mathrm{S} / \mathrm{G}_{2}(\mathrm{~N}=70)$ and the distance of cells from the crypt base were binned into $10 \mu \mathrm{m}$ intervals. Known parameters of the nuclear volume for known cell-cycle stages (Figure 3B) are overlaid. 
bioRxiv preprint doi: https://doi.org/10.1101/177477; this version posted February 14, 2018. The copyright holder for this preprint (which was not certified by peer review) is the author/funder. All rights reserved. No reuse allowed without permission.

\section{Delayed activation of the DNA replication licensing system in $\operatorname{Lgr5(+)}$ intestinal stem cells}

\section{S3 Figure. Ki67 expression along the crypt-villus axis}

1259 (A) A representative isolated crypt 1 hour after labelling with EdU (Green) and stained with 1260 an antibody against Ki67 (magenta)

1261 (B) Quantification of the distribution of Ki67(+) cells along the crypt axis. Cells were binned 1262 into four groups: Negative (Ki67(-), EdU(-)); Ki67(+), EdU(-); Ki67(+), EdU(+) and Ki67(-), $1263(\mathrm{EdU}(+)$ and by their distance from the crypt base. Data is displayed as the average 1264 percentage of a particular cell subtype, per distance bin. Data is displayed as Mean +/- SEM. 1265 Data from 75 crypts is displayed, $N=14,264$ cells. 
bioRxiv preprint doi: https://doi.org/10.1101/177477; this version posted February 14, 2018. The copyright holder for this preprint (which was not certified by peer review) is the author/funder. All rights reserved. No reuse allowed without permission.

\section{Delayed activation of the DNA replication licensing system in Lgr5(+) intestinal stem cells}

1267 S4 Figure. Delayed accumulation of Fucci2aR reporter hCdt1(30-120) in intestinal stem 1268 cells

1269 (A) Representative image of a vibratome section of intestinal tissue derived from Fucci2aR 1270 mice, stained with Hoechst (Nuclei), an antibody against Mcm2 and showing expression of 1271 the $\mathrm{G}_{1}$ marker hCdt1(30-120) and $\mathrm{S} / \mathrm{G}_{2} / \mathrm{M}$ marker hGeminin(1/110).

1272 (B) Representative images hCdt1(30-120) expression in the crypt base (left panels) and villi 1273 (right panels). Most cells in the crypt base that highly express hCdt1(30-120) are UEA(+) 1274 Paneth cells.

1275 (C) A representative image of a Fucci2aR intestinal crypt stained with Hoecsht and and antibody against Mcm2. All Mcm2(-) Paneth cells (PC) in the crypt base express high levels of hCdt1(30-120). Most Mcm2(+) stem cells in the crypt base express very low levels of hCdt1(30-120) (hCdt1 ${ }^{\text {low }}$ ). Only few Mcm2(+) cells were found to express high levels of hCdt1(30-120) (hCdt1 ${ }^{\text {High }}$ ). Many cells in the transit-amplifying compartment expressed hGeminin(1/110).

1281 (D) Quantification of the expression of Mcm2, hCdt1(30/120) and hGeminin(1/110) in Mcm2(+) and Mcm2(-) cells in the stem cell and transit-amplifying compartment. Data is displayed as a ratio of signal to the background signal detected in negative cells (Stem cell compartment: $\mathrm{Mcm} 2(+) \mathrm{N}=220, \mathrm{Mcm} 2(-) \mathrm{N}=112$; Transit-amplifying compartment: $\mathrm{Mcm} 2(+)$ $\mathrm{N}=383, \mathrm{Mcm} 2(-) \mathrm{N}=18)$. 


\section{Delayed activation of the DNA replication licensing system in $\operatorname{Lgr5(+)}$ intestinal stem cells}

S5 Figure. Manipulation of the stem cell niche can artificially induce Unlicensed- $\mathbf{G}_{1}$

1288 (A) Representative flow cytometry profile of extracted epithelial cells isolated from organoids in ENR media. The displayed image is the same profile displayed in Figure $5 \mathrm{C}$. The populations in boxed regions 1-7 are overlaid onto the individual Mcm2 and Ki67 cell-cycle profiles plotted against DNA-content (right hand box).

1292 (B) Representative bright-field images of organoids in normal (ENR) media, treated with Gefitinib for 4 days, and after 2 days in fresh ENR media post Gefitinib treatment.

(C) Representative flow cytometry profiles from extracted cells isolated from organoids treated with $10 \mu \mathrm{M}$ Chir99021 for the indicated time intervals, and after 2 days in fresh ENR media post Chir99021 treatment.

(D) Representative flow cytometry profiles from extracted cells isolated from organoids treated with normal media (ENR) or in normal media containing Chir99021 and valproic acid (ENR-CV). Displayed is the comparison of DNA-bound Mcm2 vs Ki67 content (i). The gated populations: 1) Transition (Unlicensed- $G_{1} \leftrightarrow$ intermediate $G_{0}$ ), 2) Ki67 independent origin licensing pathway, 3) Fully licensed $G_{1}$ cells, 4) Normal Licensing, 5) Unlicensed $G_{1}$ have been quantified $(\mathrm{N}=3)$.

(E) Representative images of Lgr5-GFP organoids treated with ENR or ENR-CV. In ENR-CV treated organoids, the majority of cells express Lgr5.

(F) Representative flow cytometry profiles from extracted cells isolated from organoids treated with Valproic acid for indicated time intervals, and after 2 days in fresh ENR media post Valproic acid treatment.

(G) Representative flow cytometry profiles from extracted cells isolated from organoids treated with DAPT for indicated time intervals, and after 2 days in fresh ENR media post DAPT treatment.

(H) Representative images of wild-type and $A p c^{\mathrm{Min} / \mathrm{Min}}$ intestinal organoids after treatment with $5 \mu \mathrm{M}$ Gefitinib for 3 days.

(I) Model for the unique cell-cycle characteristics of organoid epithelial cells. Normal, highly proliferative cells, express Ki67 and Mcm2 protein that is not DNA-bound (1). During a normal cell-cycle, cells are activated from Unlicensed- $\mathrm{G}_{1}$, and rapidly license origins (2). Mcms are subsequently displaced during DNA replication (3) and remain unlicensed through $G_{2}(3)$. Inhibiting EGFR causes highly proliferative cells (Ki67 ${ }^{\text {hi }}$ ) to arrest in Unlicensed- $\mathrm{G}_{1}$ with maintained $\mathrm{Mcm} 2$ protein expression. Prolonged EGFRi treatment causes transition into an intermediate state of $\mathrm{G}_{0}$ accompanied by loss of Ki67 expression $\left(\mathrm{Ki} 67^{\mathrm{lo}}\right)$, but maintenance of $\mathrm{MCM} 2-7$ protein expression (4). Induction of terminal differentiation by inhibition of Notch signalling is associated with a terminal loss of MCM2-7 proteins, and entry into deep- $\mathrm{G}_{0}(5)$. Notch activation (or HDAC inhibition (HDACi)) induces a unique subset of $\mathrm{Ki} 67^{\mathrm{lo}}$ Unlicensed- $\mathrm{G}_{1}$ cells to license origins independently of Ki67 6). We suggest that the unique cell population observed upon ENR-CV / ENR-V treatment may be a reserve subset of stem cells that express Lgr5 and start expressing MCM2-7 and enter 
bioRxiv preprint doi: https://doi.org/10.1101/177477; this version posted February 14,2018 . The copyright holder for this preprint (which was not certified by peer review) is the author/funder. All rights reserved. No reuse allowed without permission.

Delayed activation of the DNA replication licensing system in $\operatorname{Lgr5}(+)$ intestinal stem cells

1328 Unlicensed- $\mathrm{G}_{1}$ from deep- $\mathrm{G}_{0}$. These cells have unique cell cycle characteristics, and can 1329 immediately license origins independently of Ki67 expression $(6 \rightarrow 2 \rightarrow 3)$.

\section{S1 Movie. Cell-cycle clones}

A 3D rotation of a representative intestinal crypt showing nuclei (Blue), DNA-bound Mcm2 (Red) and EdU (Green; 1 hour pulse). The crypt base is at the bottom of the image. An isosurface rendering of nuclei within the crypt has also been performed, and have been coloured to match specific cell-cycle stage: Unlicensed (Blue), $G_{1}$ Licensed (Red), Early Sphase (Yellow), Late $S / G_{2}$ (Green). 
bioRxiv preprint doi: https://doi.org/10.1101/177477; this version posted February 14, 2018. The copyright holder for this preprint (which



Mcm2 Phalloidin

D



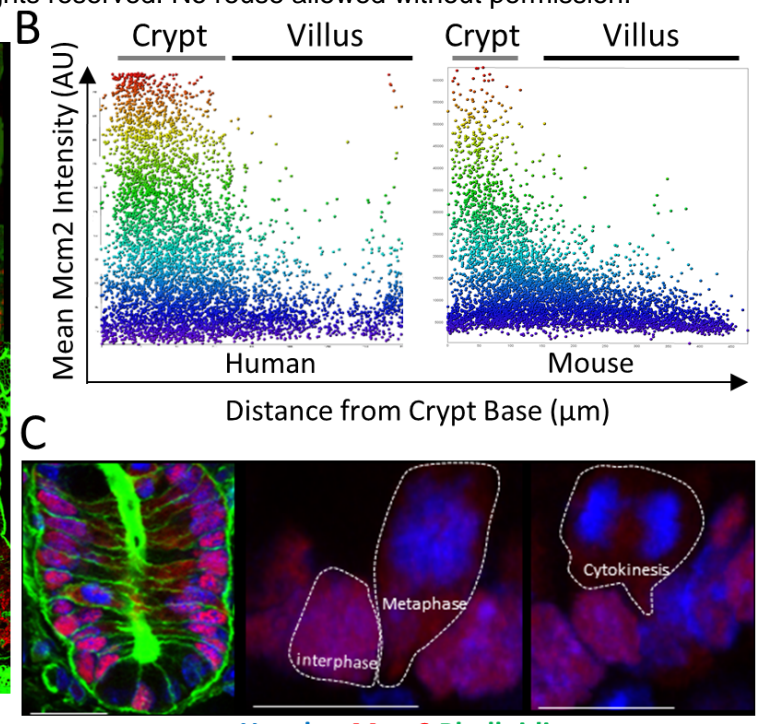

Hoechst Mcm2 Phalloidin



F

Paneth Cells
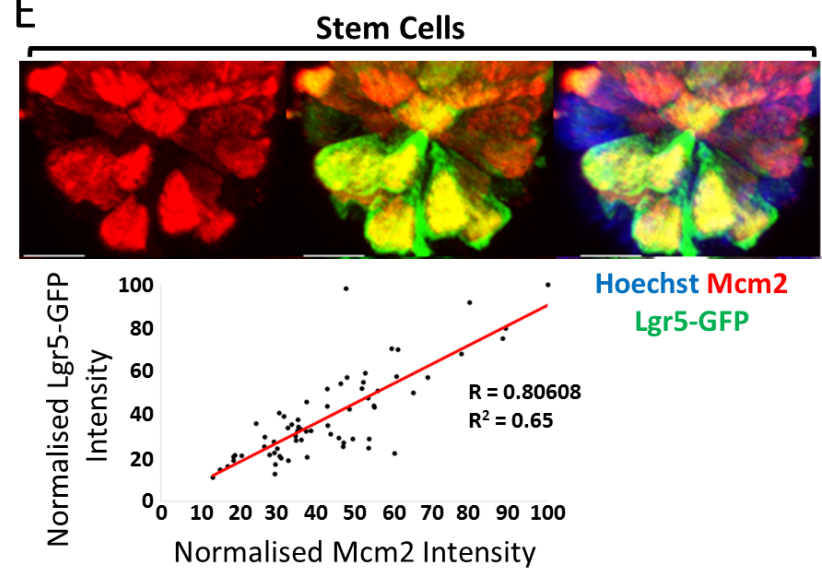

G



Hoechst Mcm2 UEA



Hoechst Mcm2

UEA Phalloidin

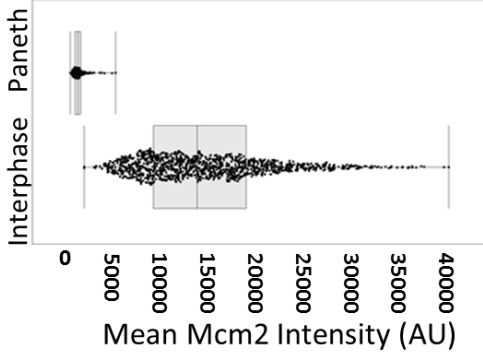

$\mathrm{H}$

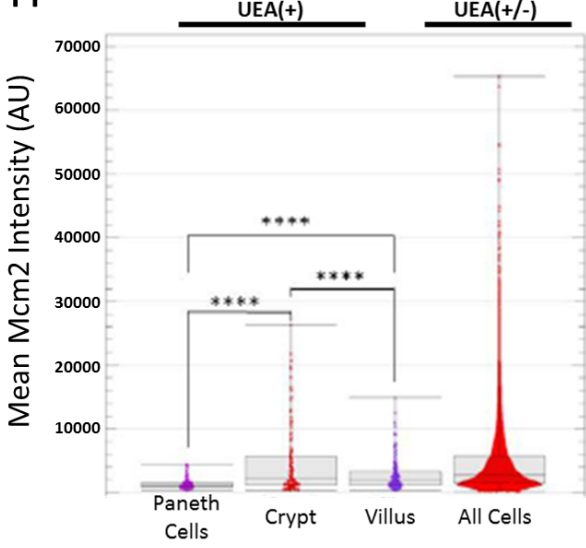


A

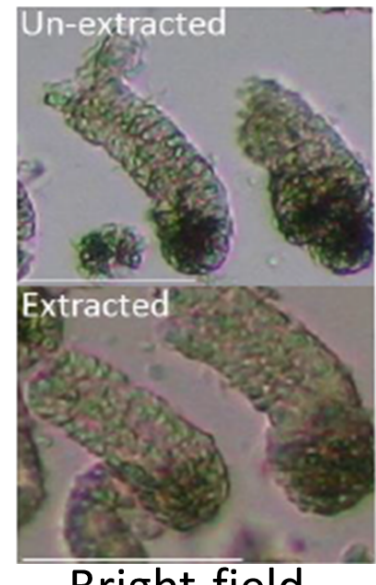

Bright-field

D

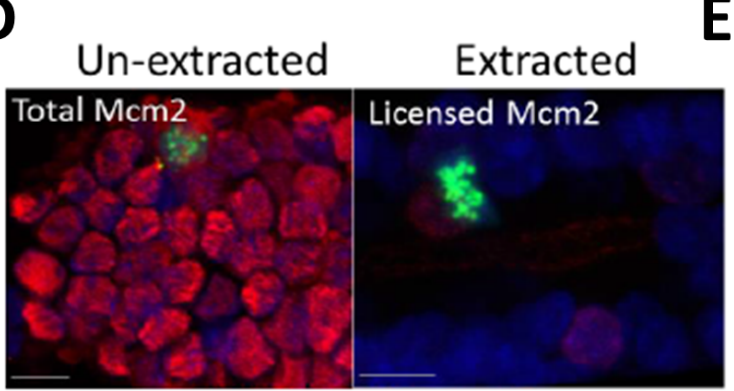

Hoechst Mcm2 pH-H3

$\mathbf{F}$

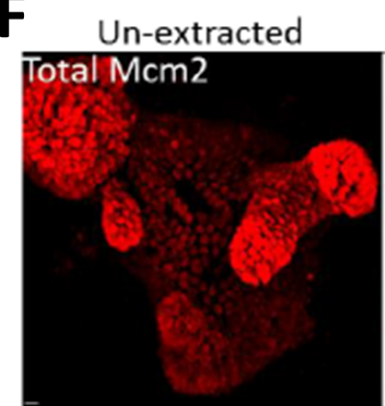

$\mathbf{E}$
B

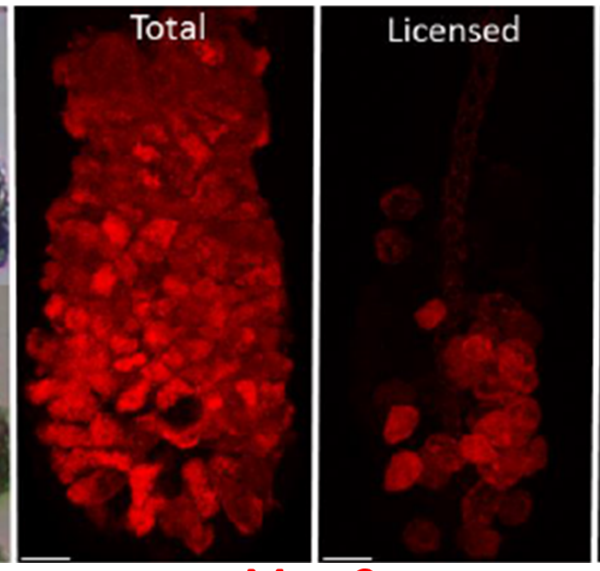

$\mathrm{Mcm} 2$
C
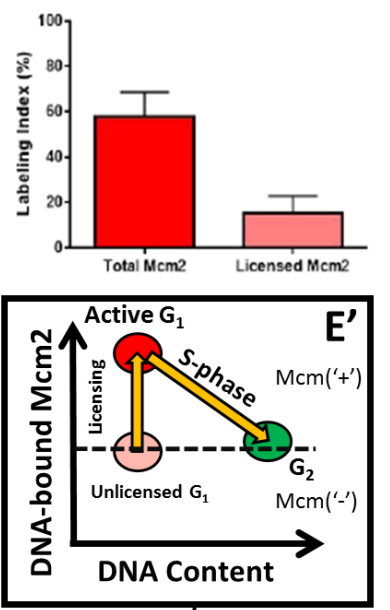

$E^{\prime}$
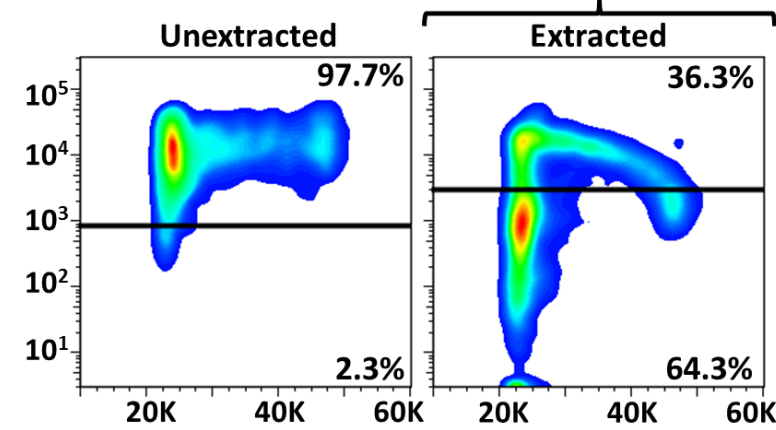

G

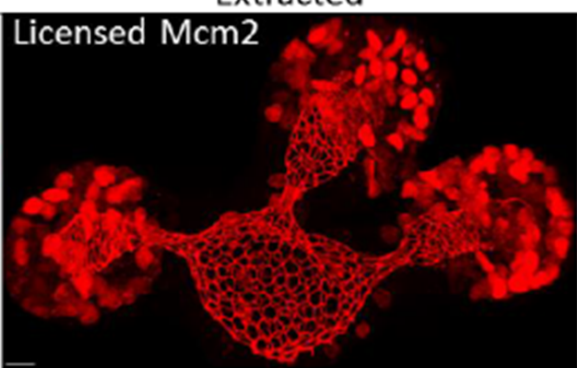

$\mathrm{Mcm} 2$



Carroll et al., Figure 2 

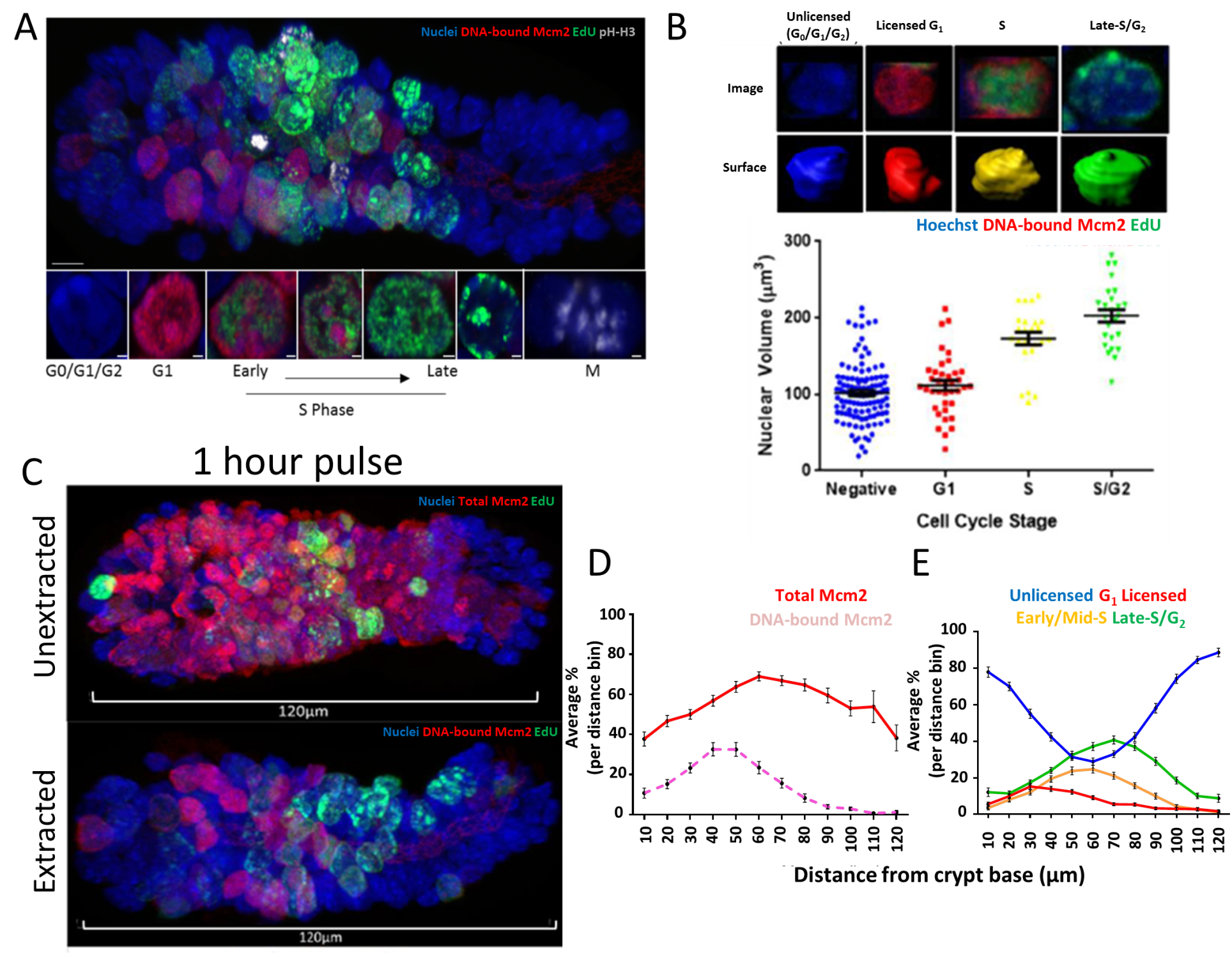

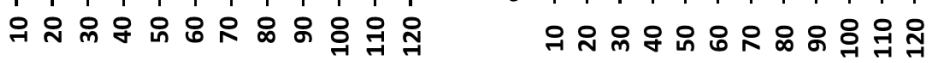
Distance from crypt base ( $\mu \mathrm{m})$

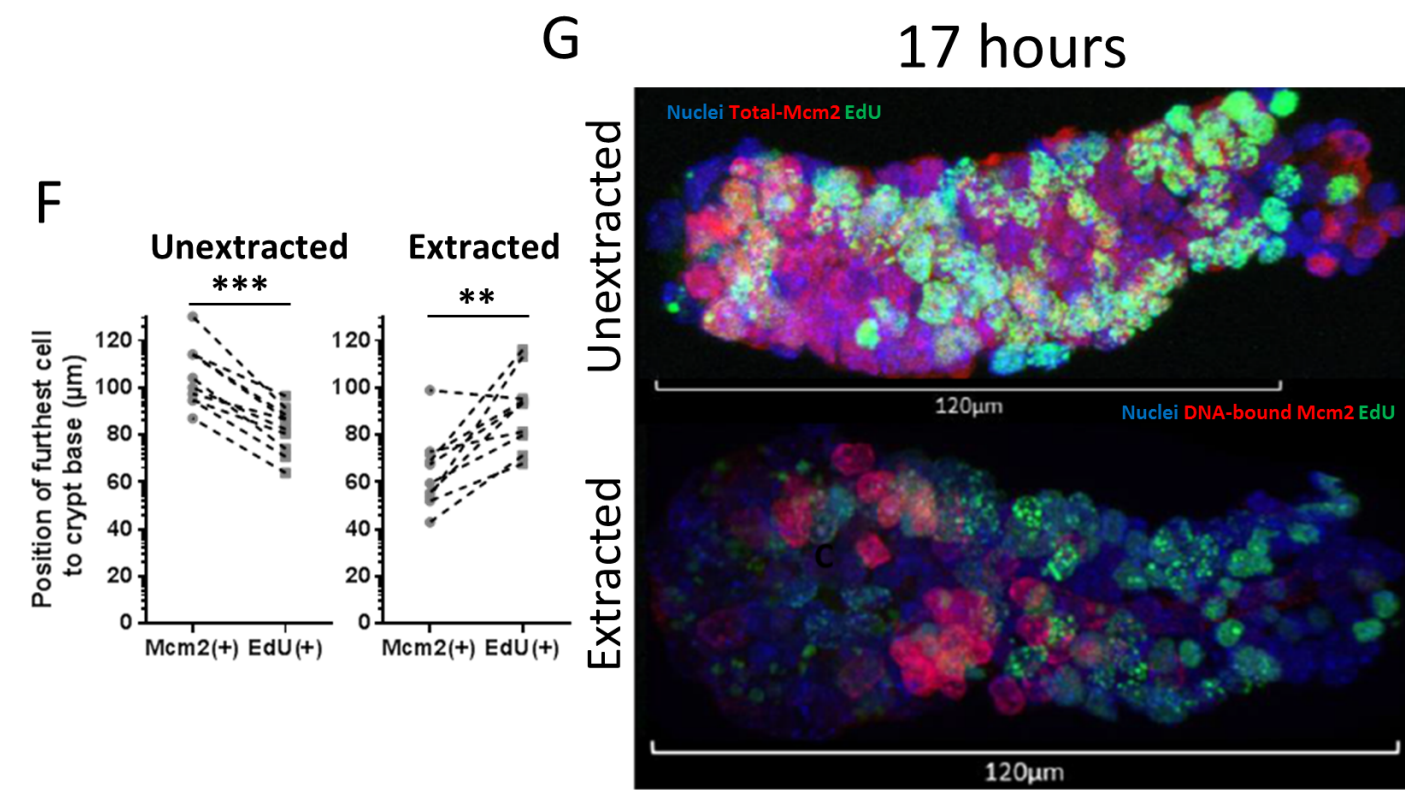

$\mathrm{H}$

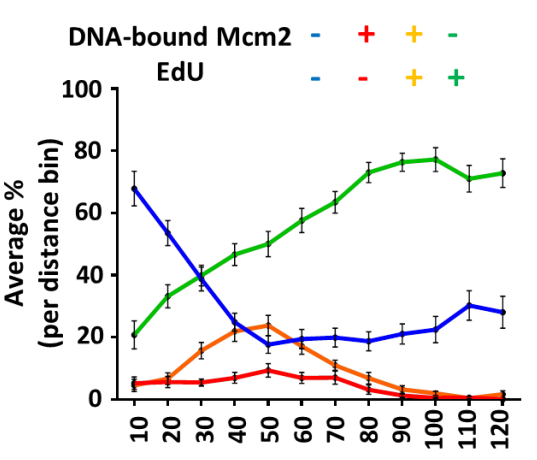

Distance from crypt base $(\mu \mathrm{m})$

Carroll et al., Figure 3 
bioRxiv preprint doi: https://doi.org/10.1101/177477; this version posted February 14, 2018. The copyright holder for this preprint (which was not certified by peer review) is the author/funder. All rights reserved. No reuse allowed without permission.

A



B

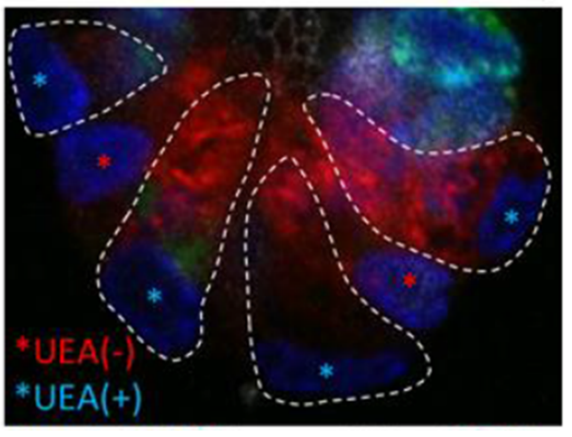

Hoechst DNA-bound Mcm2 EdU UEA
C

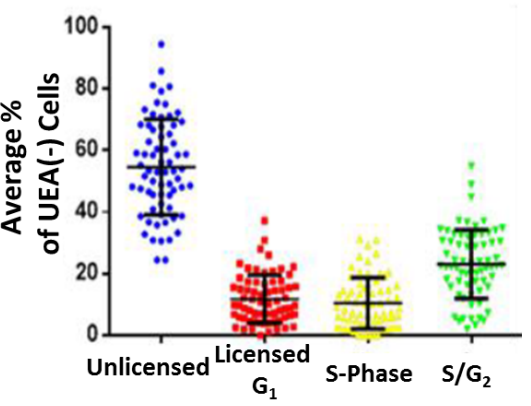

\section{Lgr5-GFPHi}



iii

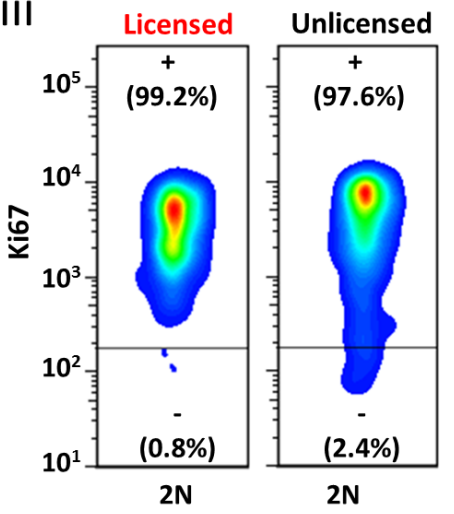

E of Mcm2(+) $G_{1} \operatorname{Lgr} 5(+)$ Cells
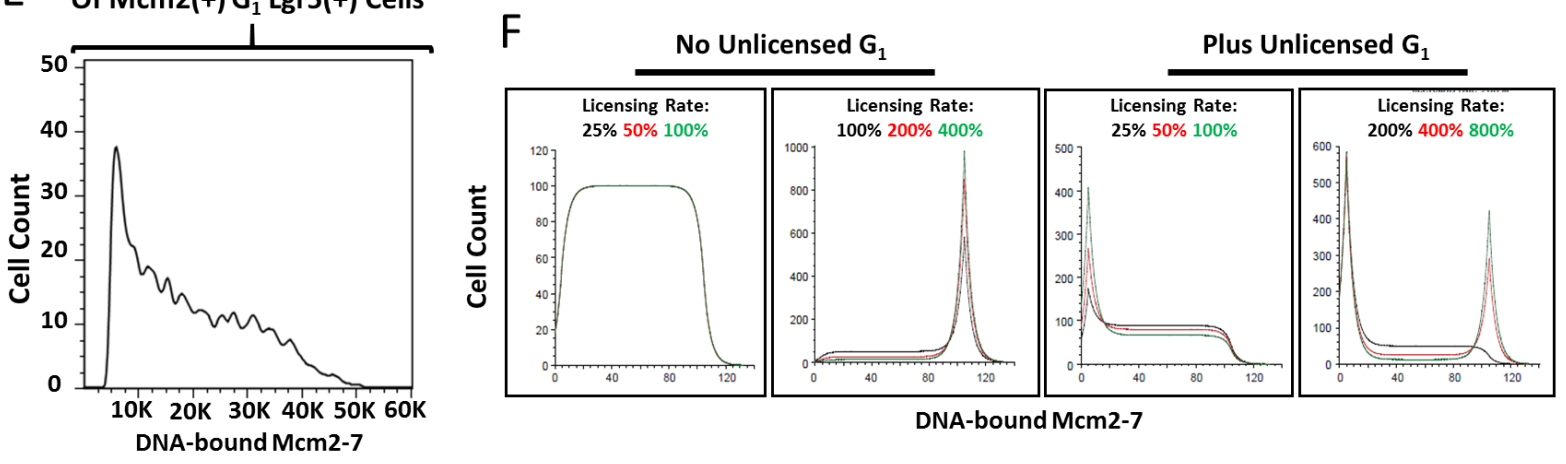

G
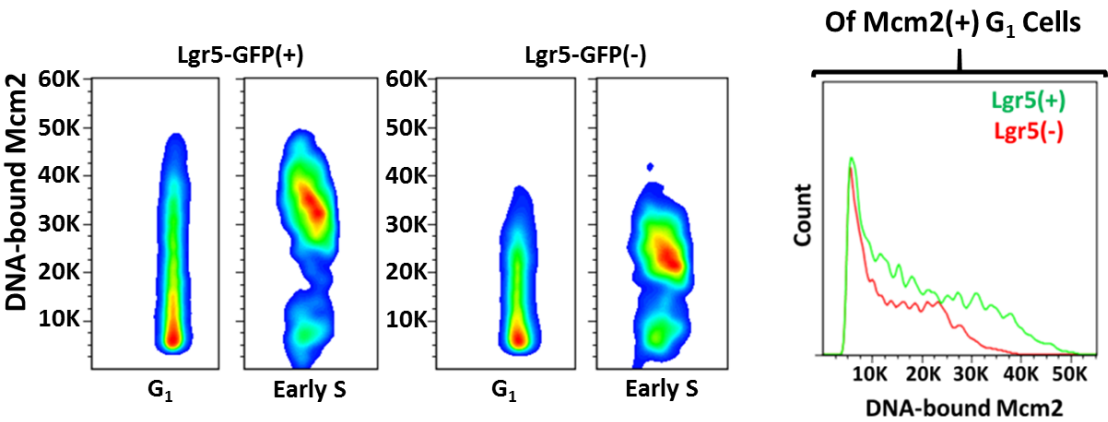

Carroll et al., Figure 4 
A

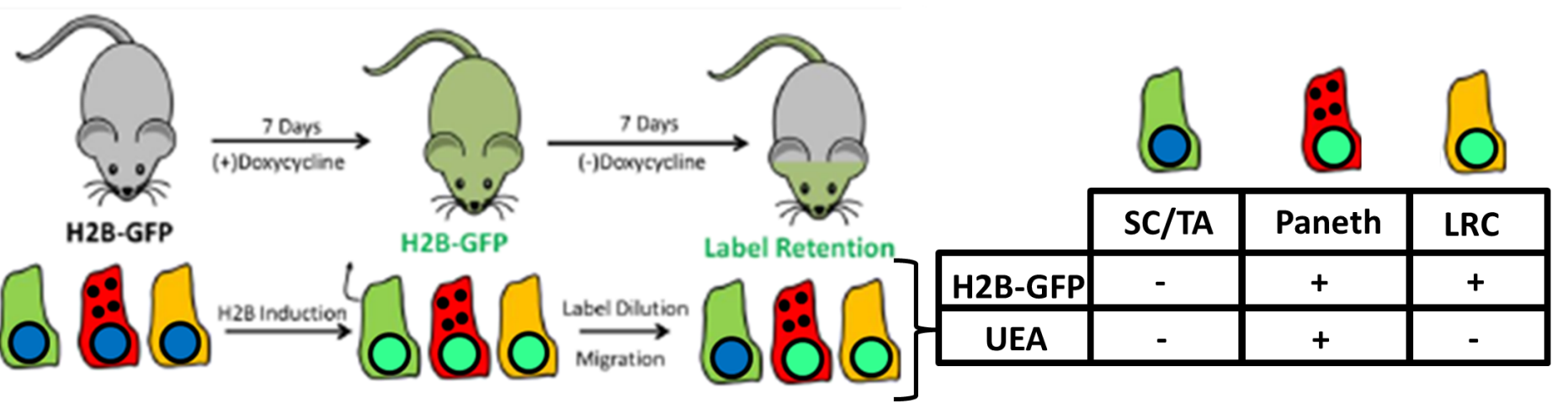



7 Day Induction

Ci

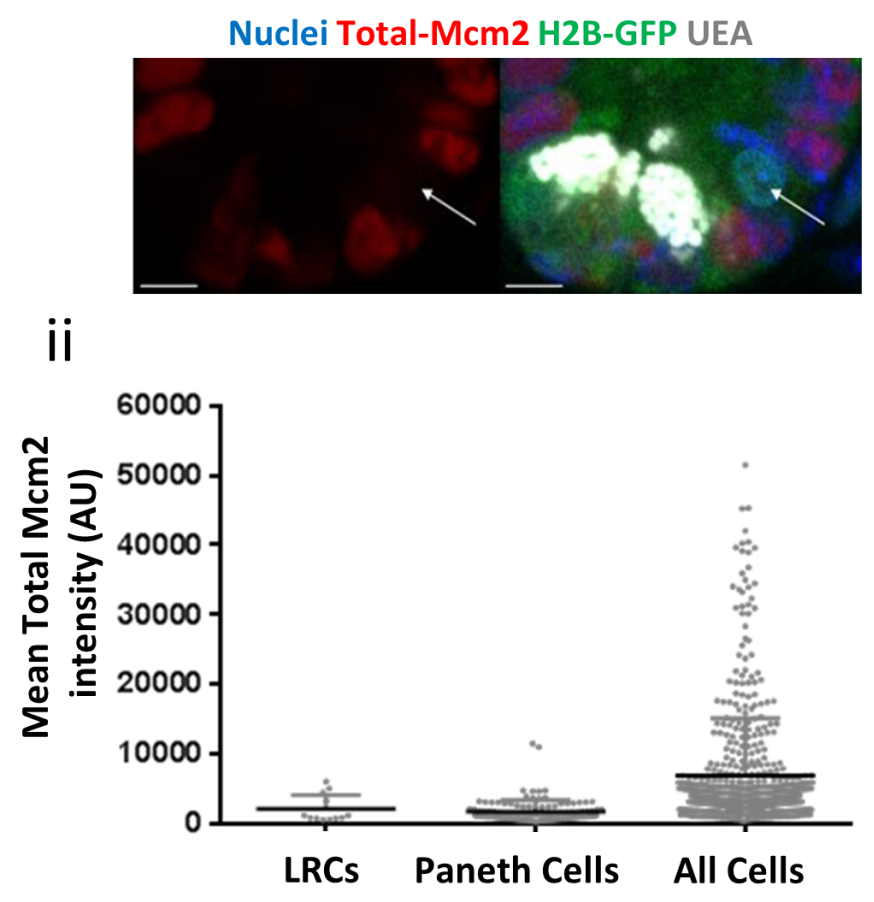

Nuclei Total-Mcm2 H2B-GFP UEA
Nuclei Mcm2 H2B-GFP UEA

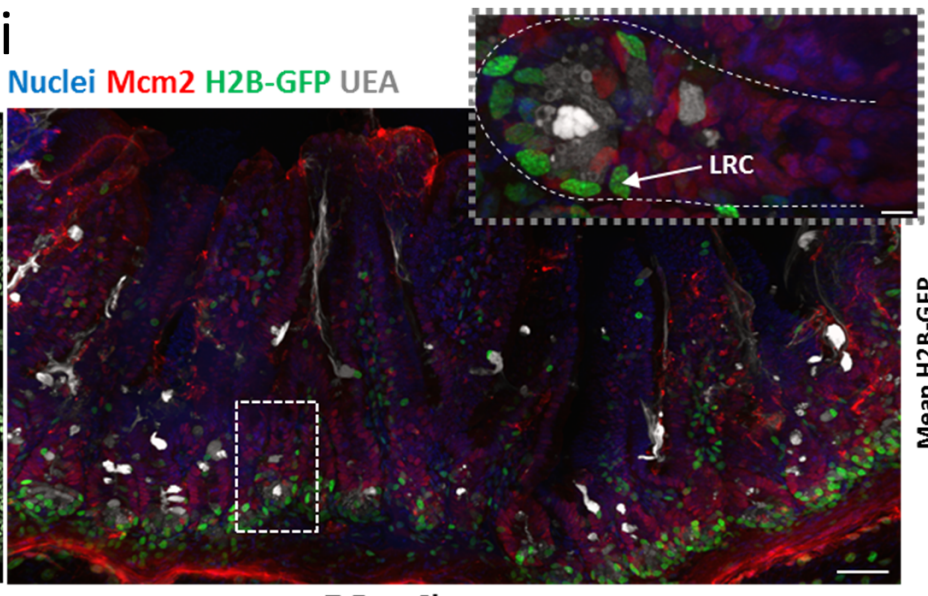

+7 Day Chase

iii

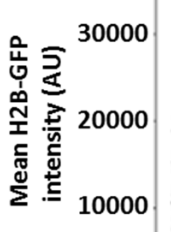

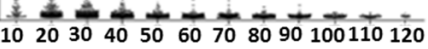
Distance from Crypt base $(\mu \mathrm{m})$ iii

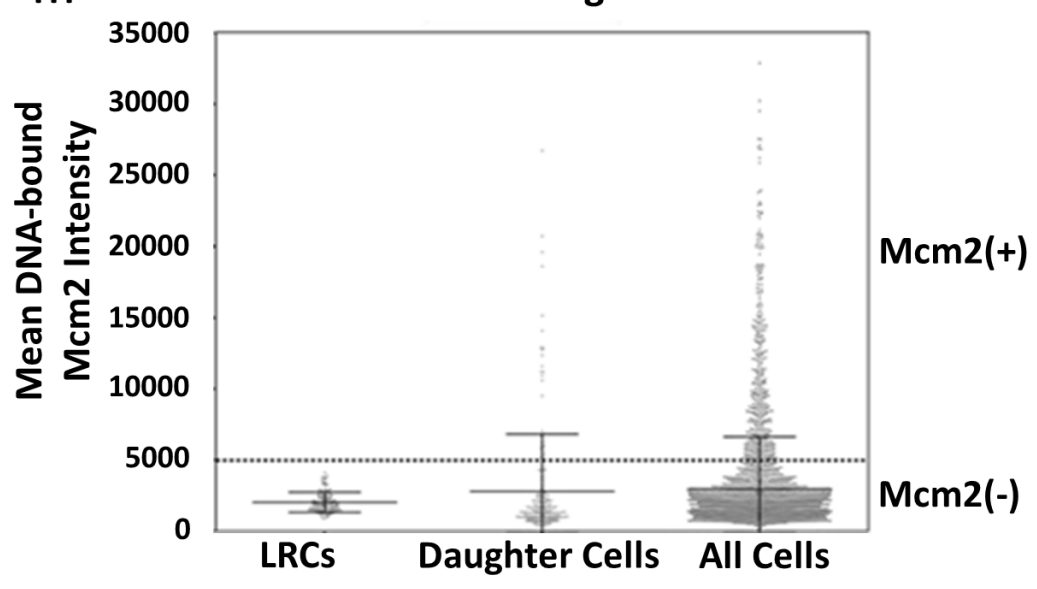



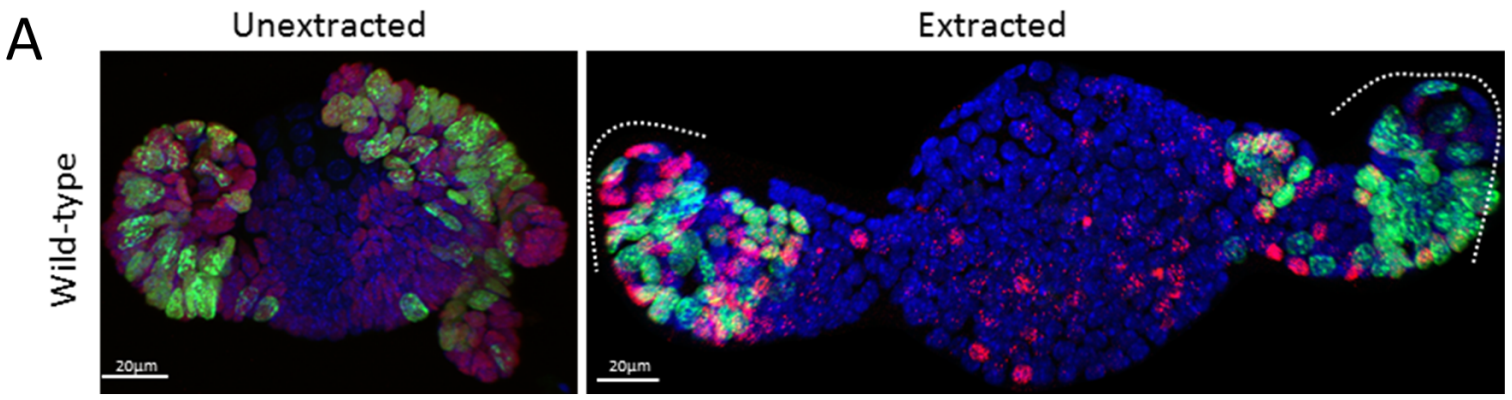

Nuclei Mcm2 EdU

B

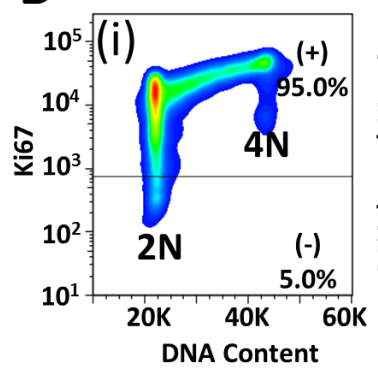

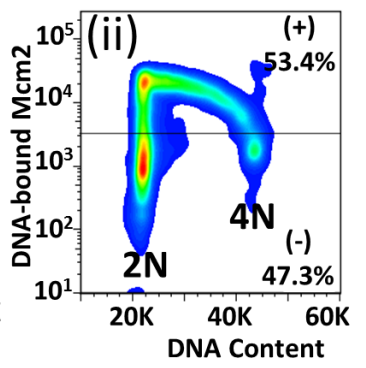

$\mathrm{C}$ (i) Organoids

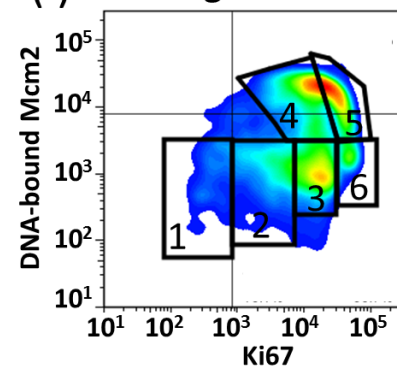

(ii) Intestinal Crypts

(iii) ${ }^{100 \%}$
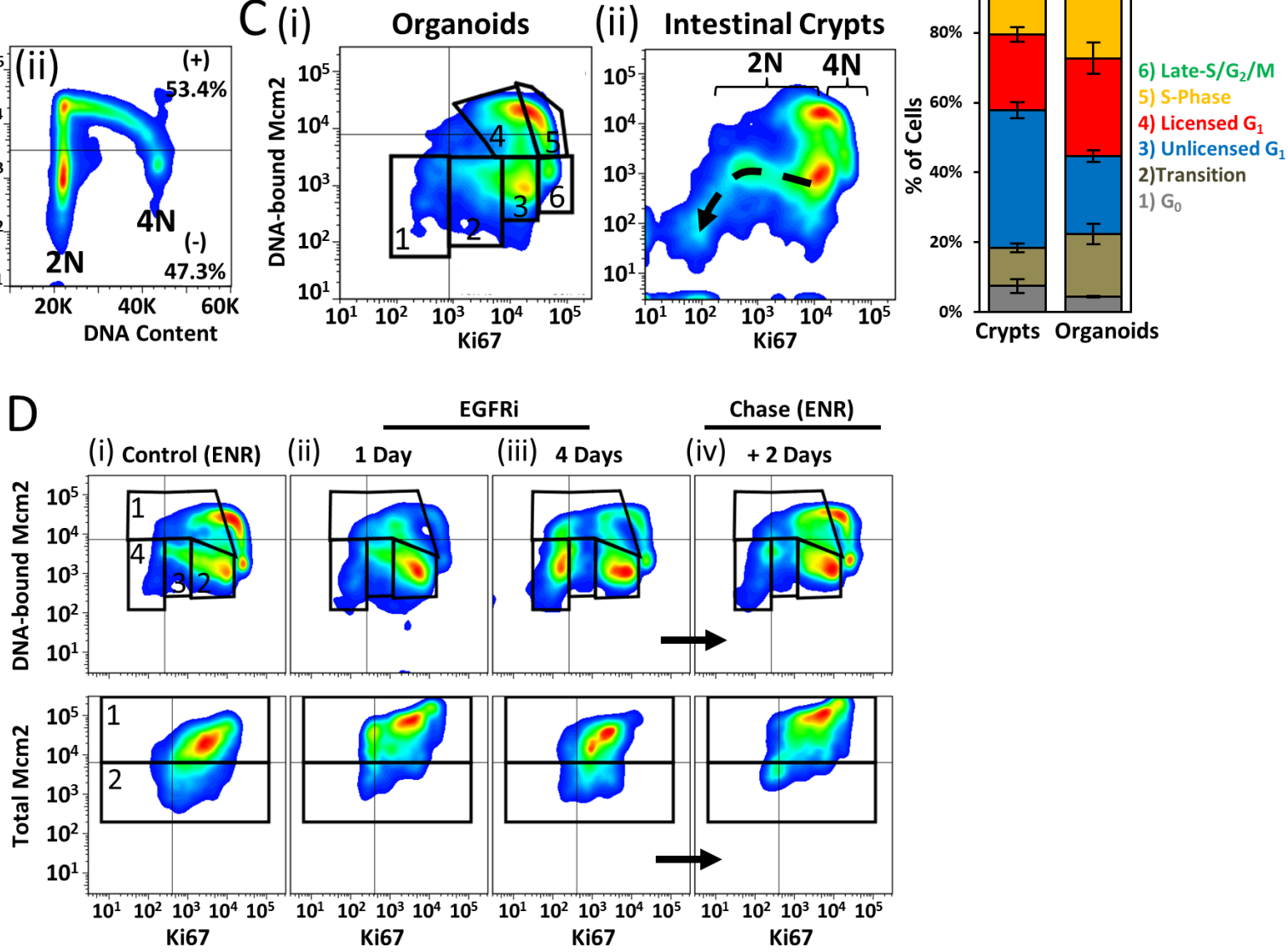

$\mathrm{Ei}$

(DNA-Bound Mcm2)



ii

(Total Mcm2)

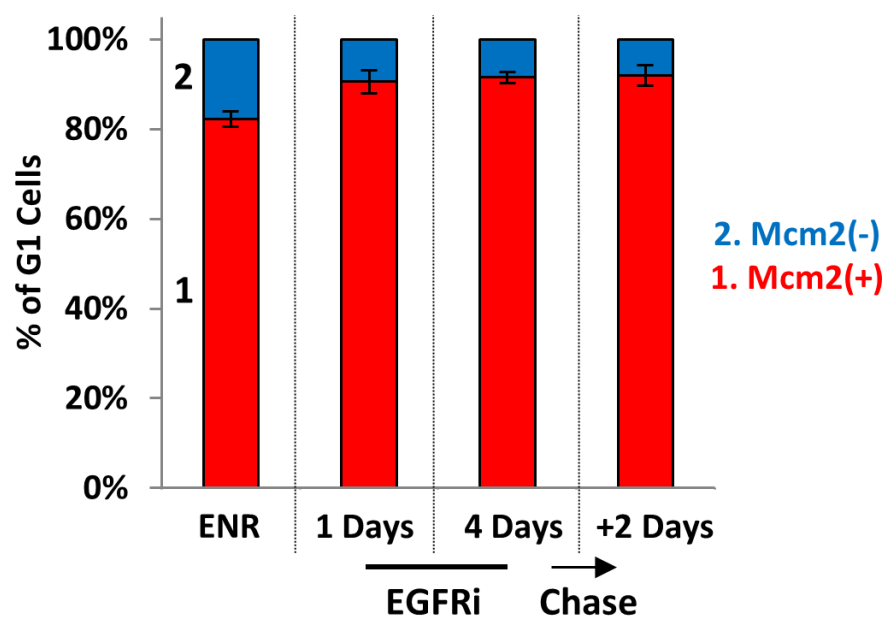



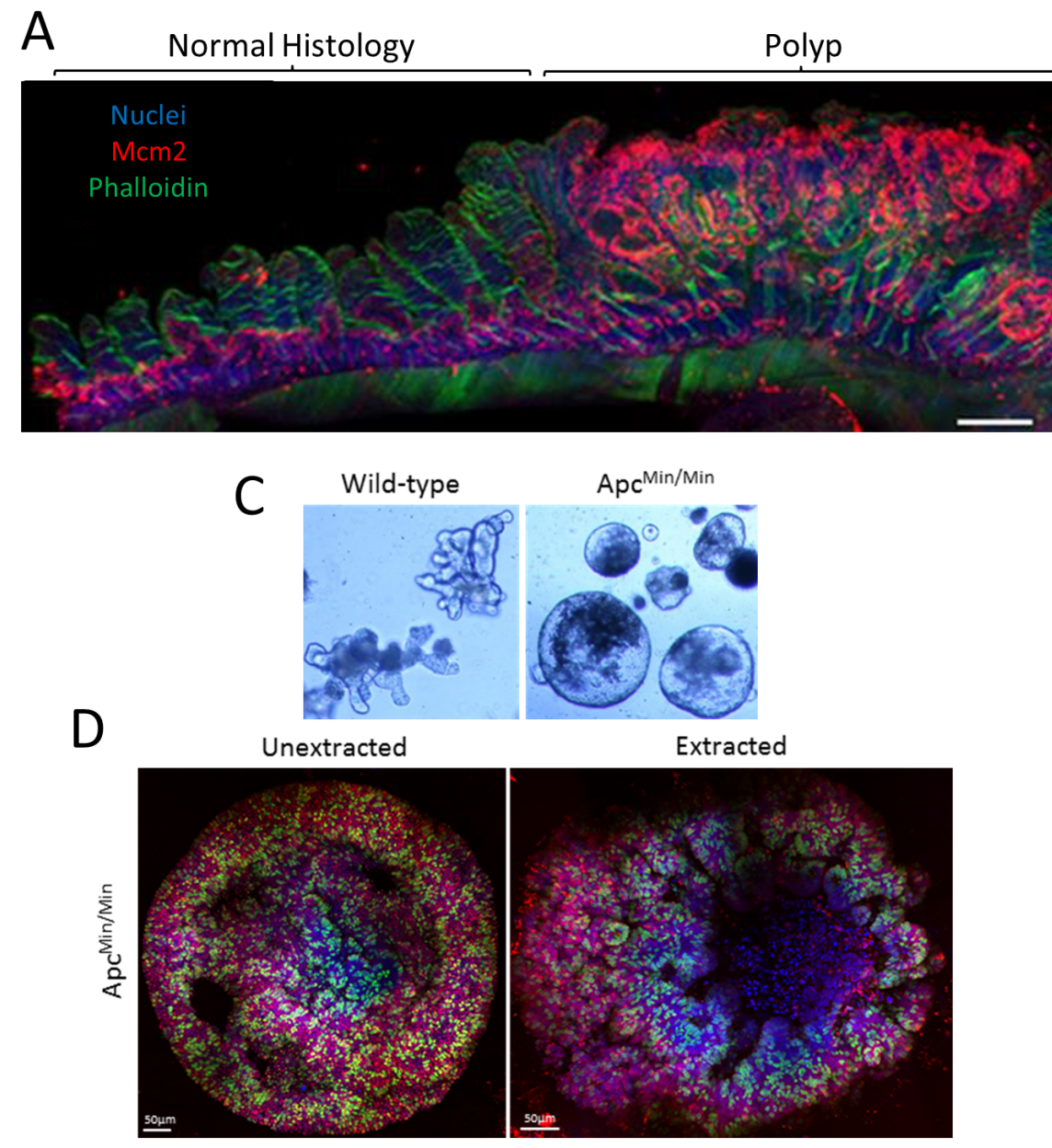
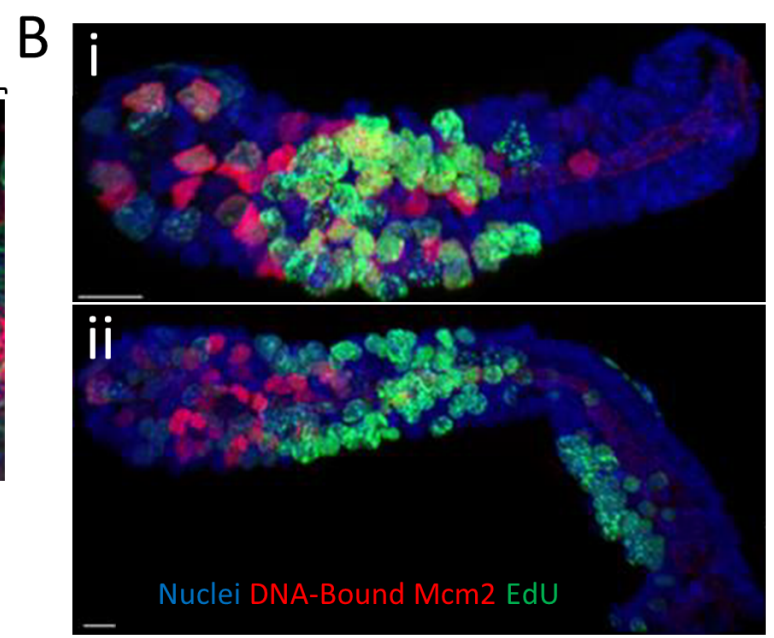

iii



Distance from crypt base $(\mu \mathrm{m})$

Nuclei Mcm2 EdU
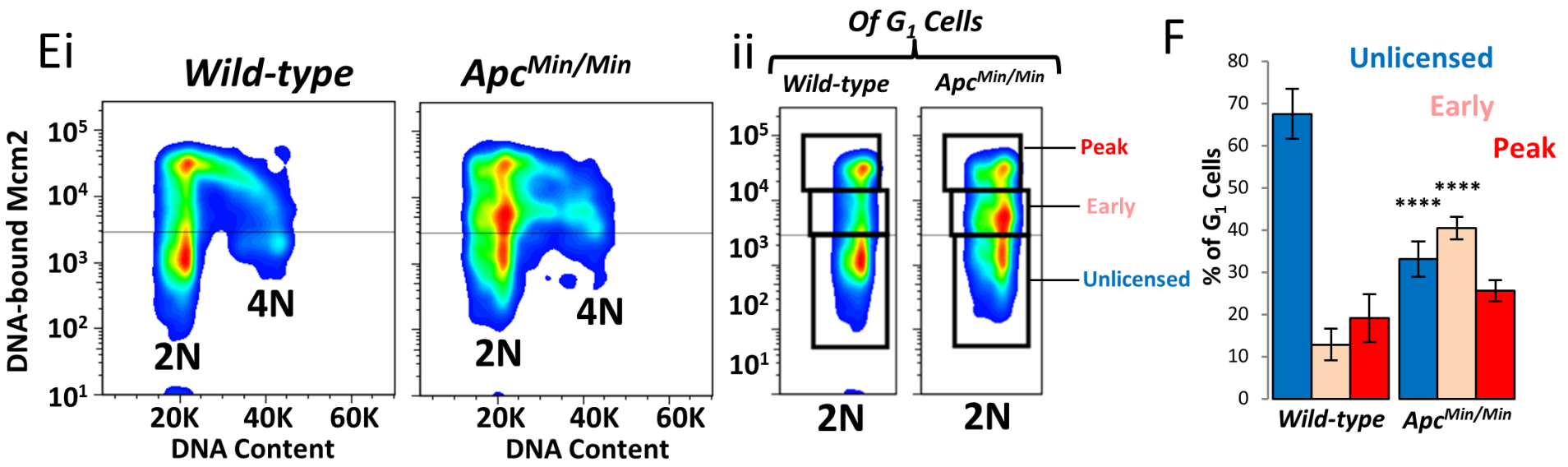

G

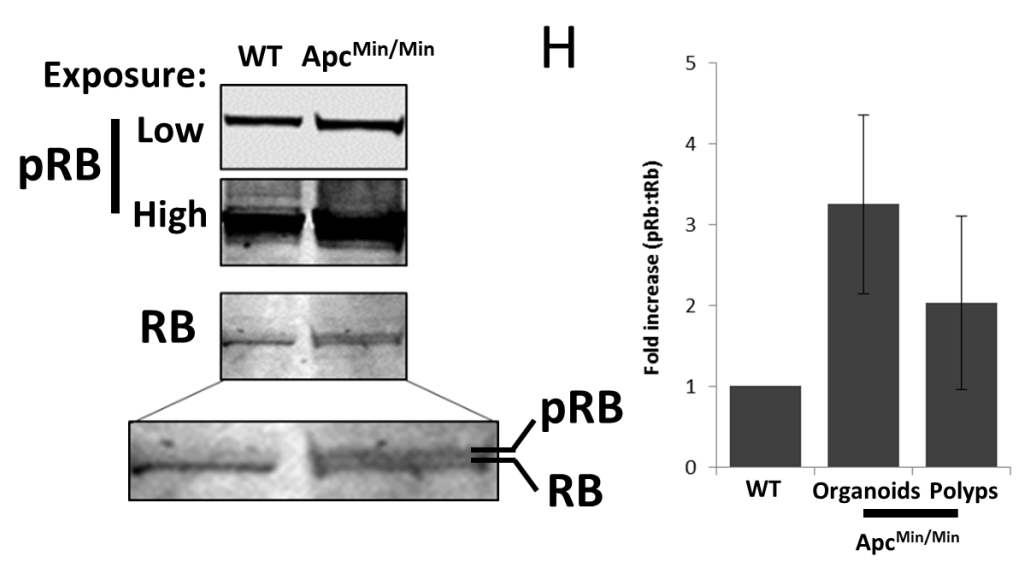

Carroll et al., Figure 7 
bioRxiv preprint doi: https://doi.org/10.1101/177477; this version posted February 14, 2018. The copyright holder for this preprint (which was not certified by peer review) is the author/funder. All rights reserved. No reuse allowed without permission.

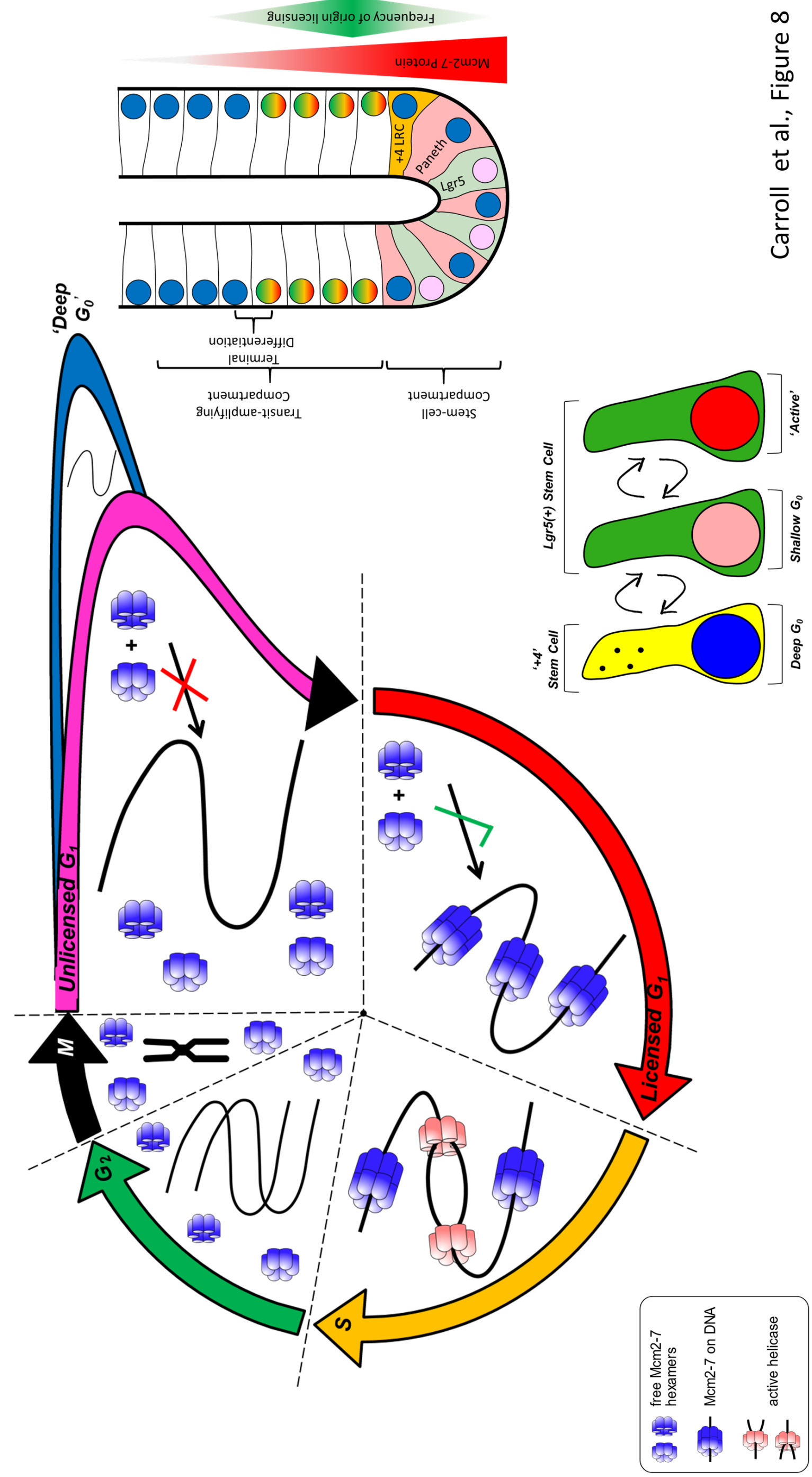


A

\section{Image acquisition and cropping}

\section{Manual detection}

of nyclei

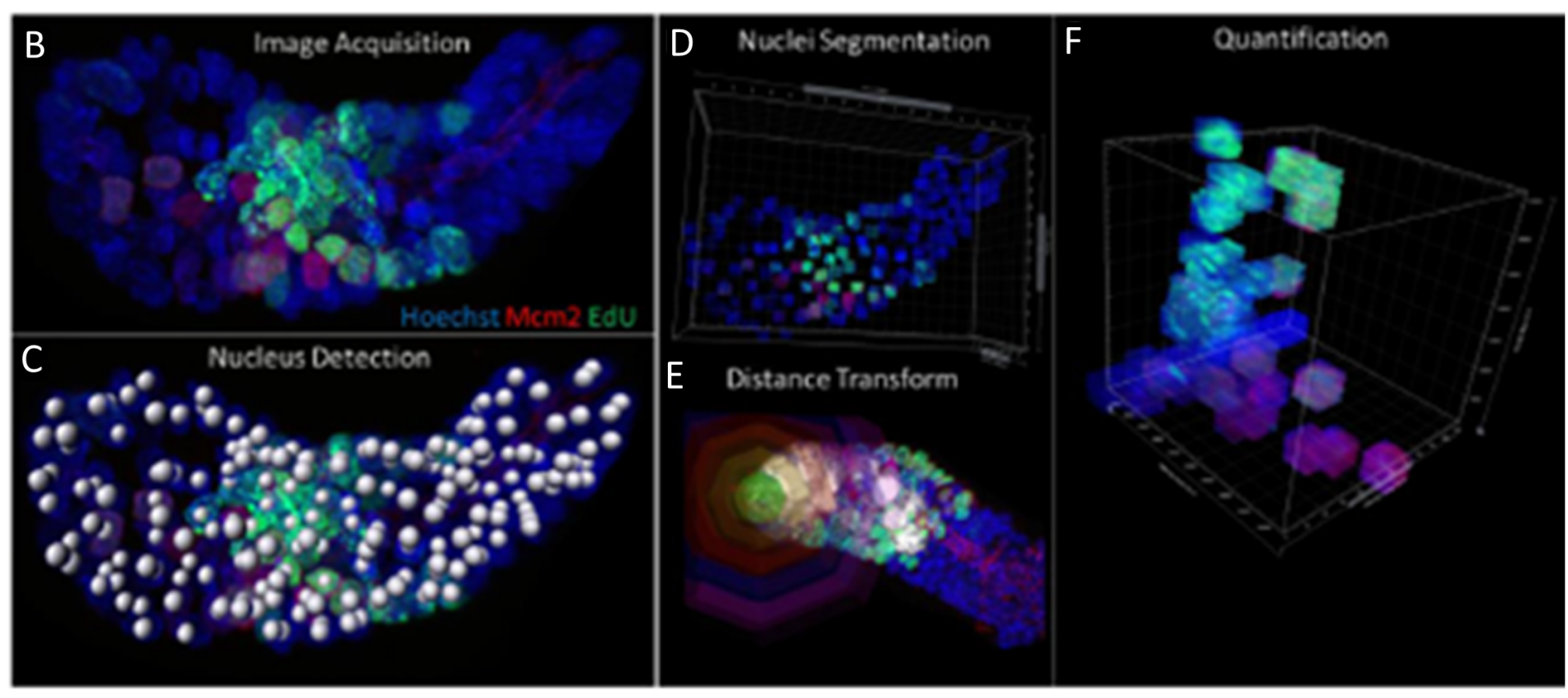

G

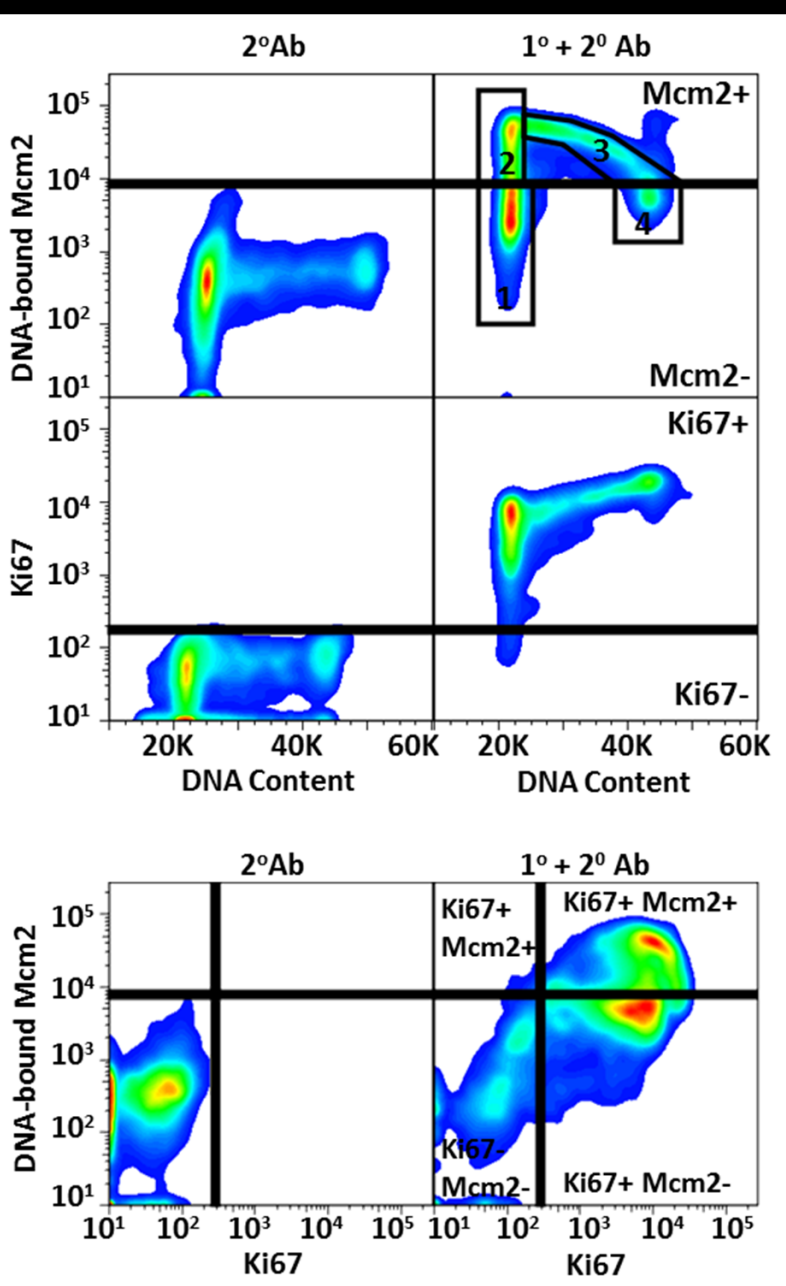
A

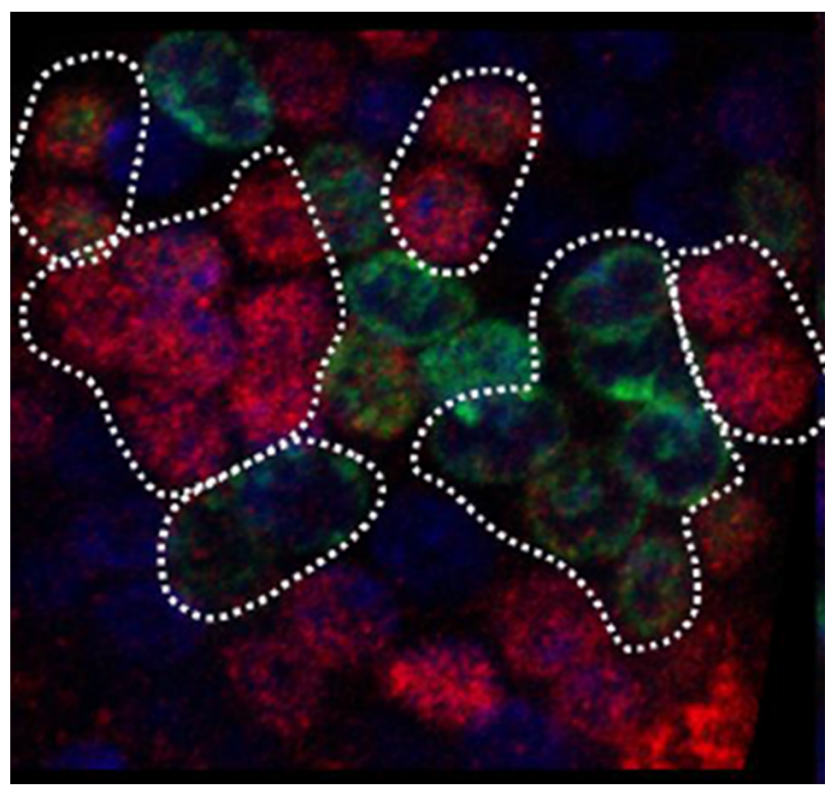

Hoechst DNA-bound Mcm2 EdU (1 Hour pulse)


Carroll et al., S2 Figure
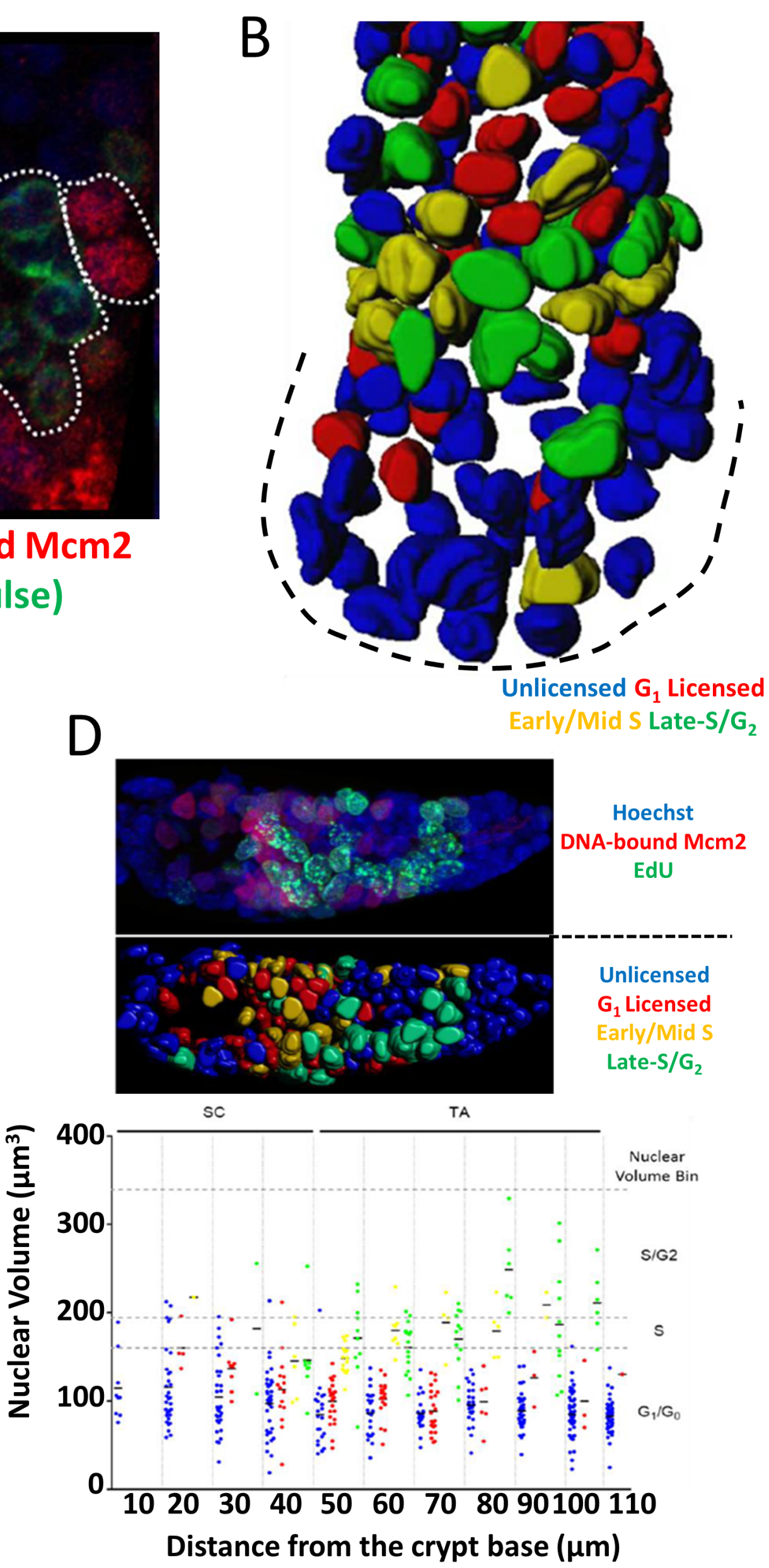

Staining pattern: Unlicensed $\mathrm{G}_{1}$ Licensed Early/Mid S Late-S/G 2 

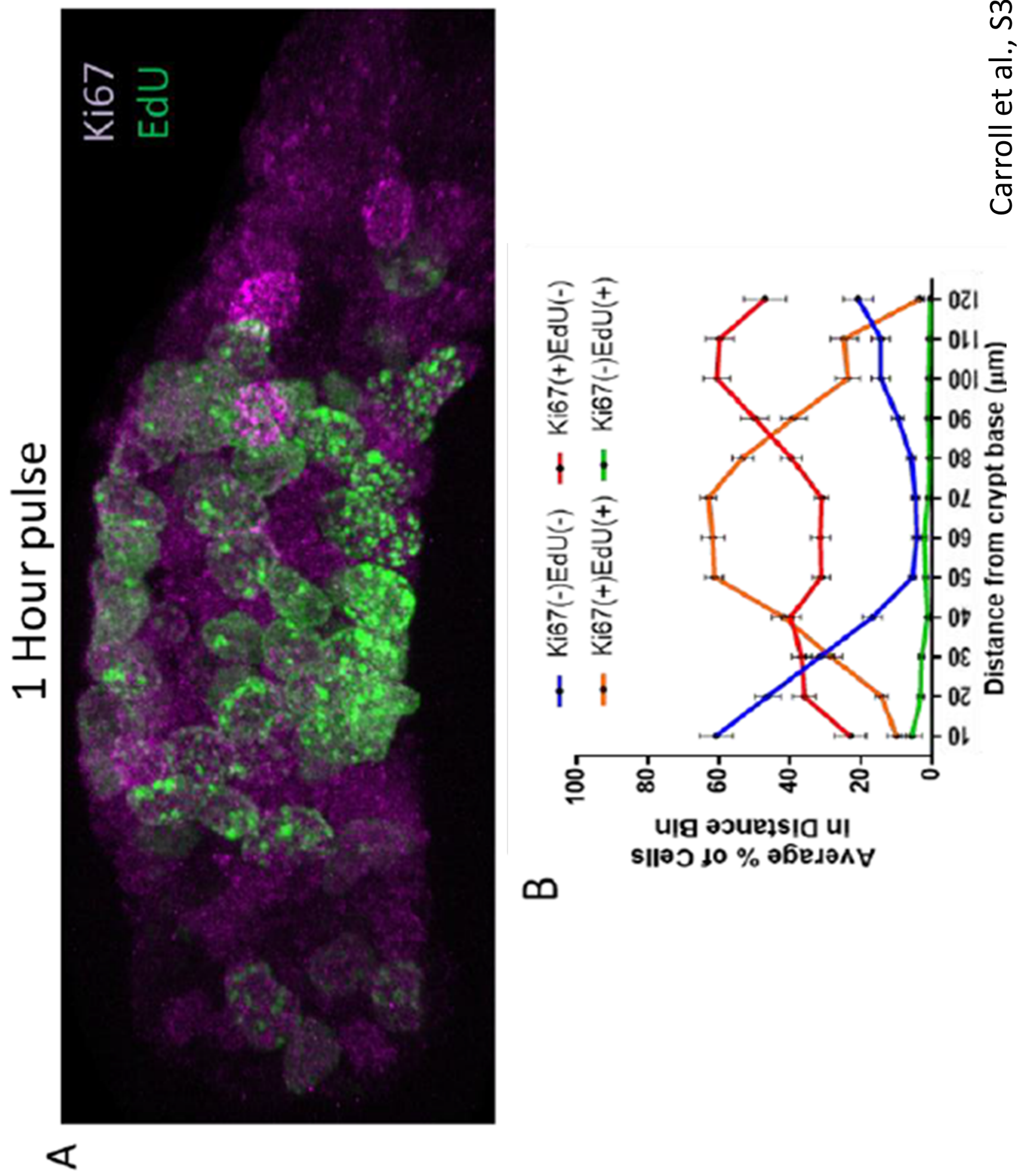
bioRxiv preprint doi: https://doi.org/10.1101/177477; this version posted February 14, 2018. The copyright holder for this preprint (which

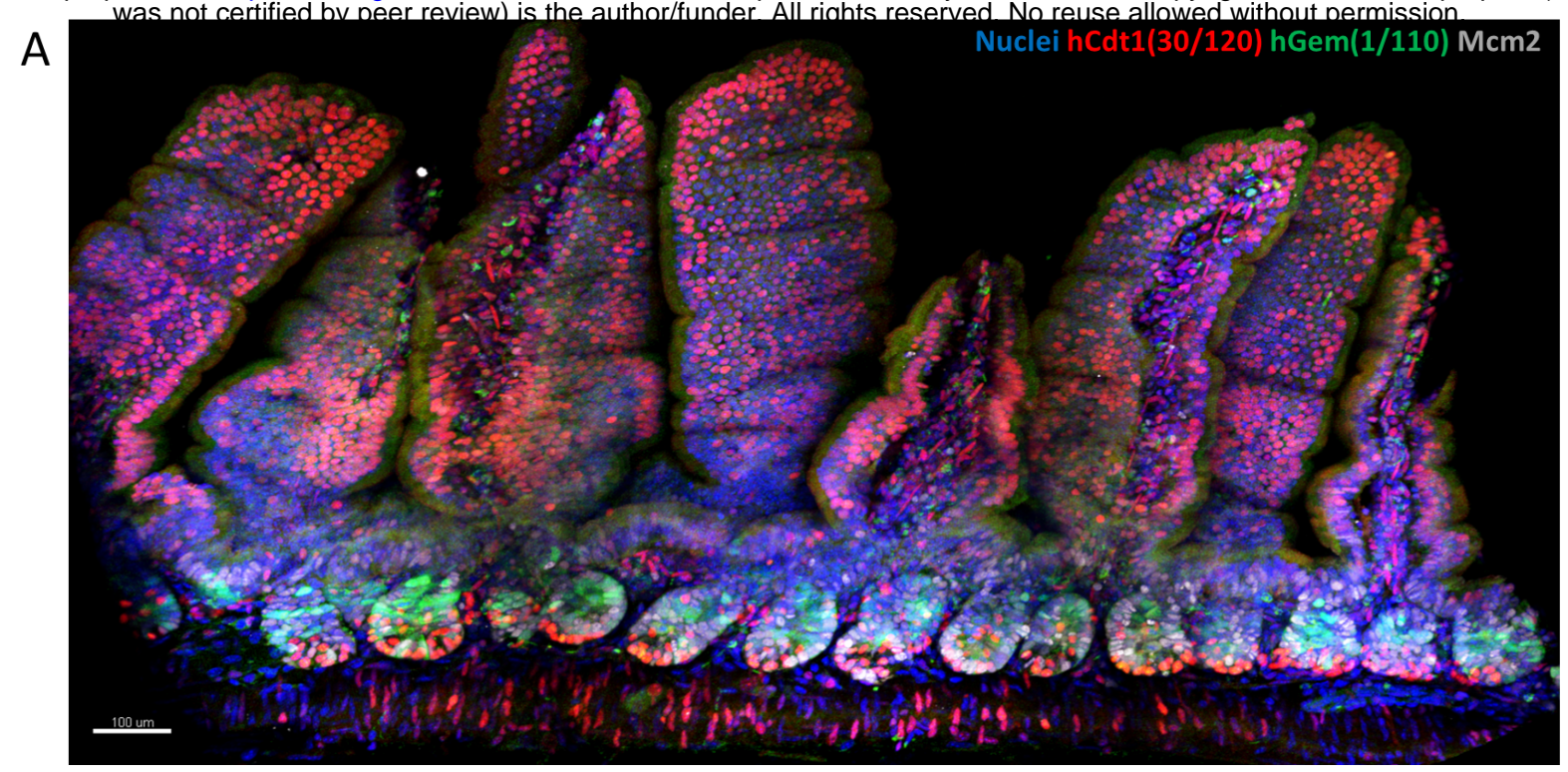

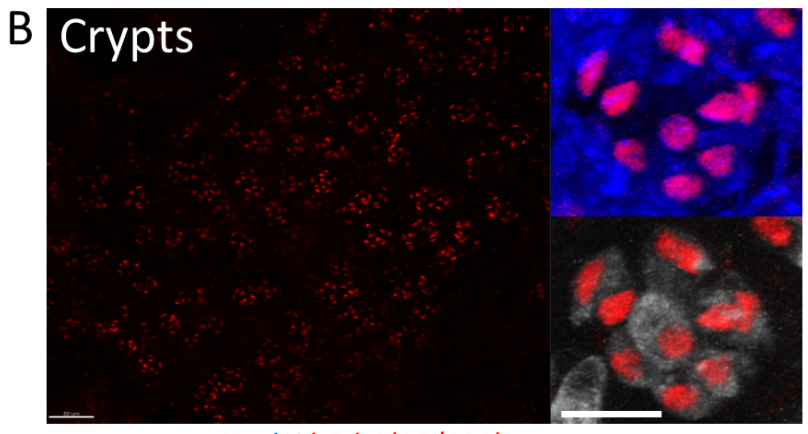

Nuclei hCdt1(30/120) Lysozyme



hCdt1(30/120)

C

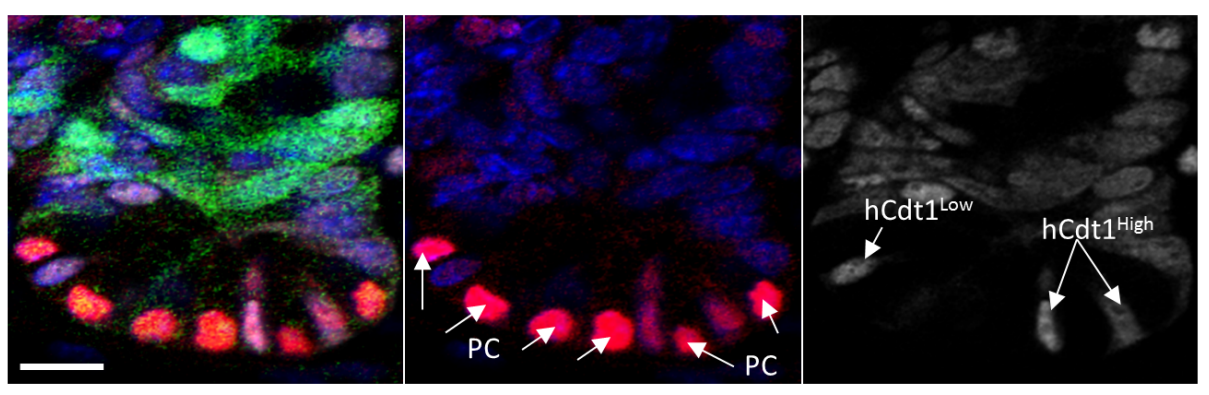

Nuclei hCdt1(30/120) hGem(1/110) Mcm2

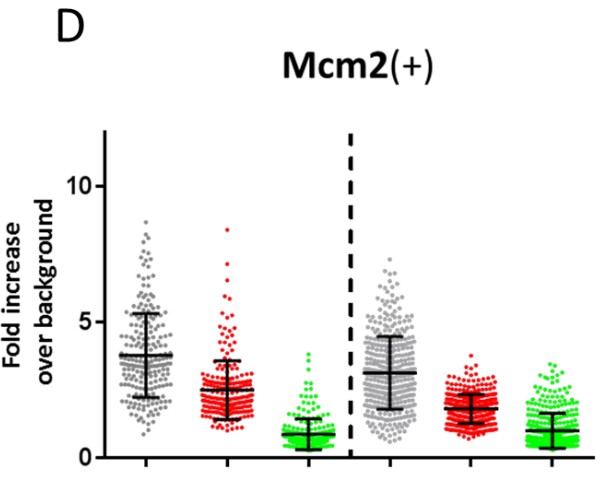

Stem Cell Transit-amplifying

Compartment
Mcm2(-)

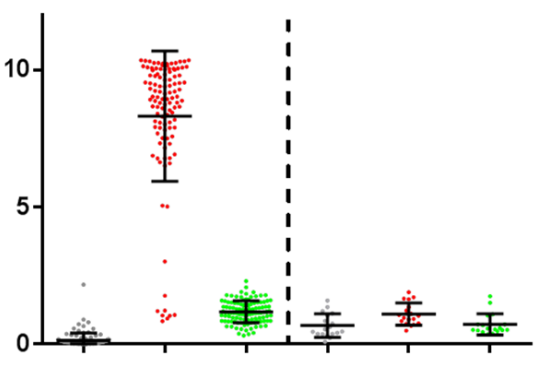

Stem Cell Transit-amplifying

Compartment

\section{Mcm2}

hCdt1(30/120)

hGeminin(1/110) 

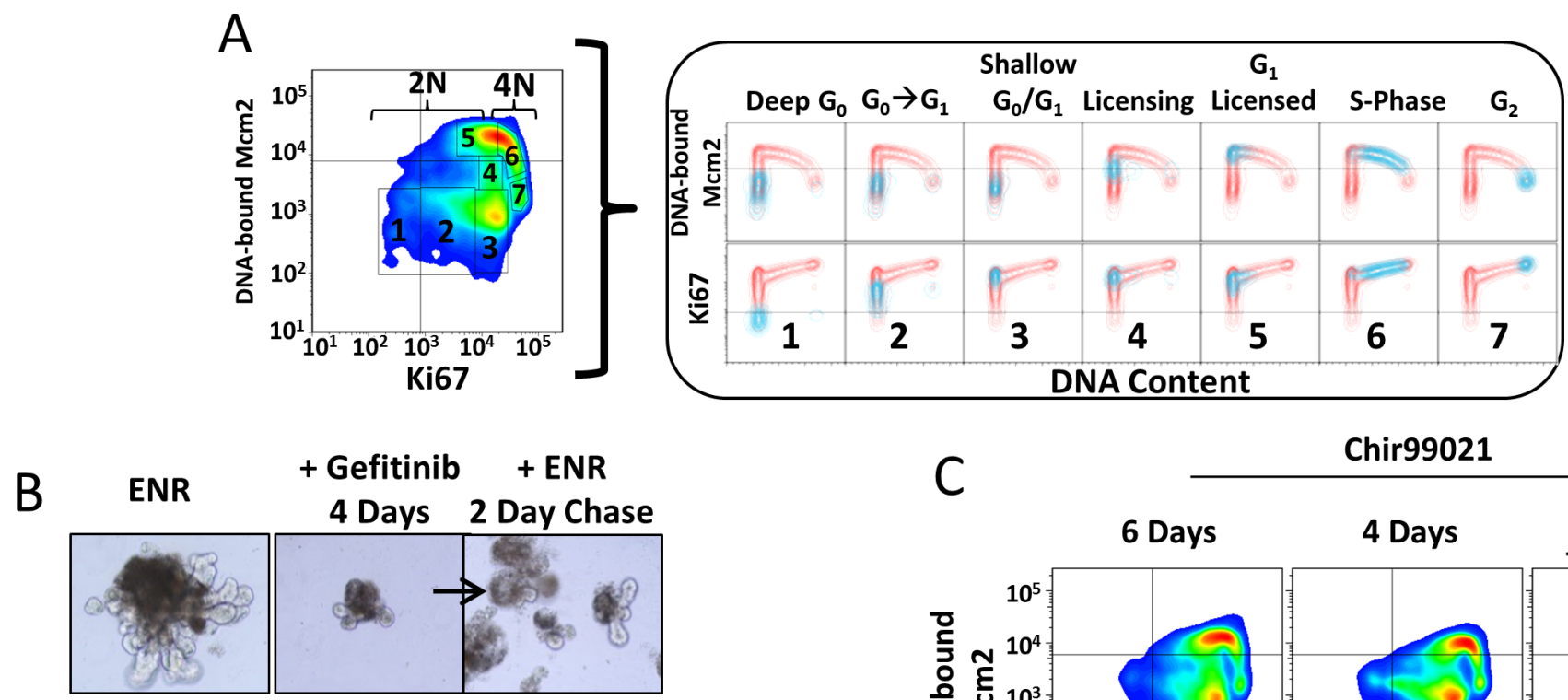

Di

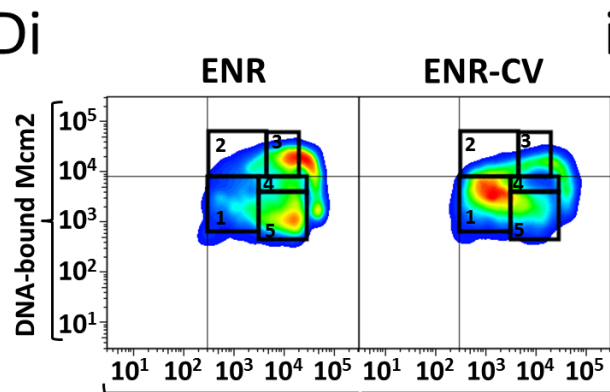

$E$ Ki67

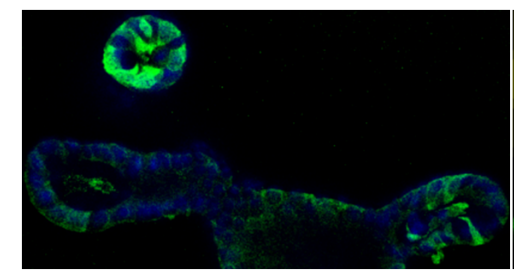

ii ${ }_{100 \%}$

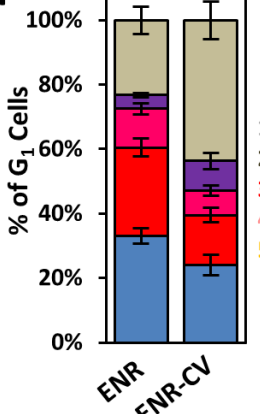

Hoechst Lgr5-GFP
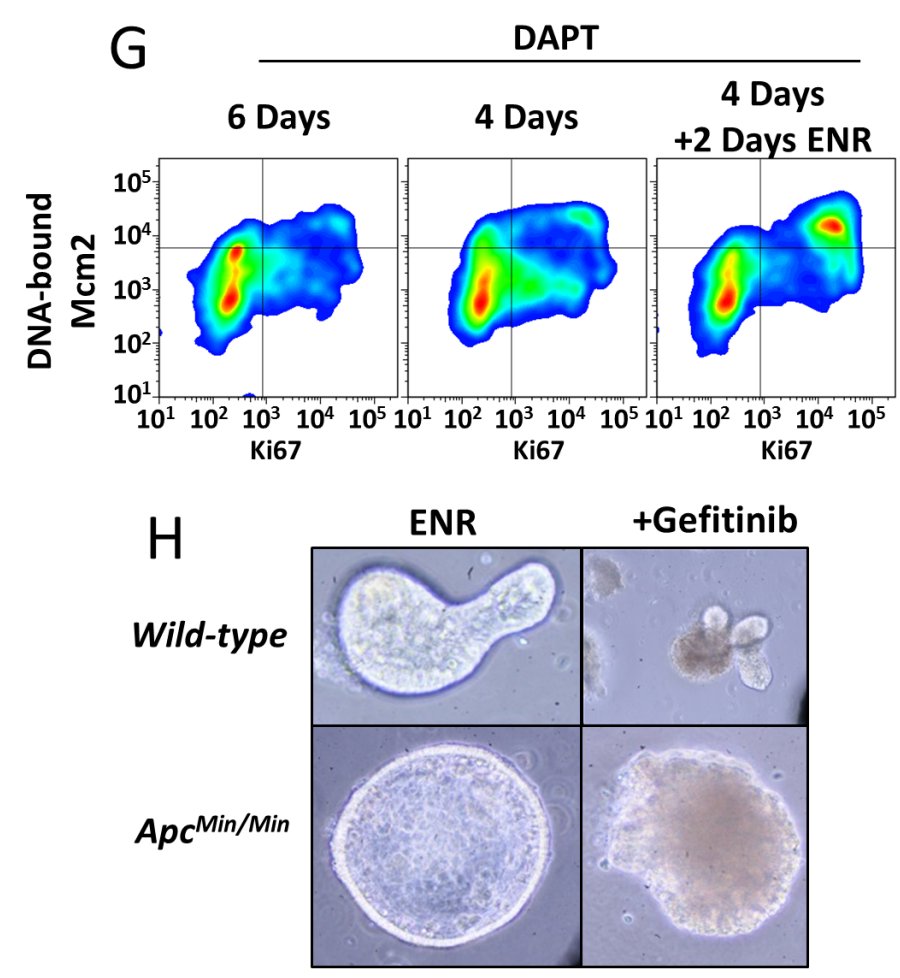

C Chir99021



1) Transition

2) Ki67 Independent

3) Fully Licensed

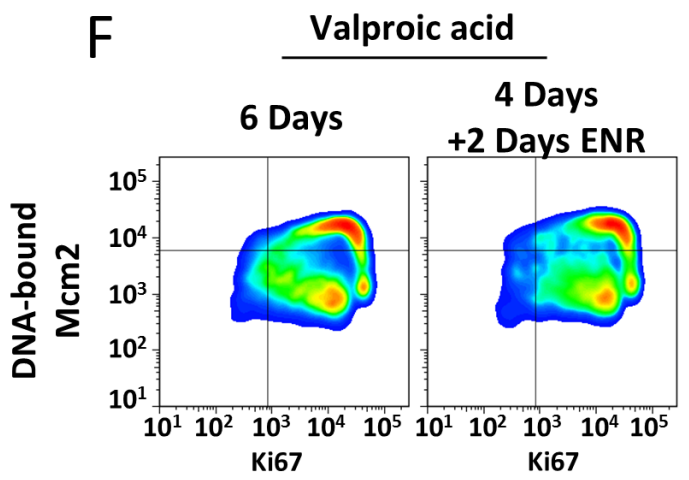

।



Ki67 